\title{
Protein Engineering Strategies for Improved Pharmacokinetics
}

\author{
Aurélie Rondon, Sohaib Mahri, Francisco Morales-Yanez, Mireille Dumoulin, \\ and Rita Vanbever*
}

Protein therapeutics have gained momentum in recent years and become a pillar in treating many diseases and the only choice in several ailments. Protein therapeutics are highly specific, tunable, and less toxic than conventional small drug molecules. However, reaping the full benefits of therapeutic proteins in the clinics is often hindered by issues of immunogenicity and short half-life due essentially to fast renal clearance and enzymatic degradation. Advances in polymer chemistry and protein engineering allowed overcoming some of these limitations. Strategies to prolong the half-life of proteins rely on increasing their size and stability and/or fusing them to endogenous proteins (albumin, Fc fragment of antibody) to hijack physiological pathways involved in protein recycling. On the downside, these modifications might alter therapeutic proteins structure and function. Therefore, a compromise between half-life and activity is sought. This review covers half-life extension strategies using natural and synthetic polymers as well as fusion to other proteins and sheds light on genetic engineering strategies and chemical and enzymatic reactions to achieve this goal. Promising strategies and successful applications in the clinics are highlighted.

\section{Introduction}

Since the market introduction of recombinant human insulin in 1982, biopharmaceuticals have gained momentum. More than 200 protein therapeutics are currently on the market and above 1000 are in clinical development. ${ }^{[1]}$ Antibodies continue to largely dominate biopharmaceutical approvals because their clinical applications are multiple in a wide range of diseases including cancer, cardiovascular diseases, organ transplantation, autoimmunity, inflammation, and infections. Protein therapeutics present several advantages over small molecule drugs. ${ }^{[2]}$ Proteins serve a highly specific and complex set of physiological

Dr. A. Rondon, Dr. S. Mahri, Prof. R. Vanbever

Advanced Drug Delivery and Biomaterials

Louvain Drug Research Institute

Université catholique de Louvain (UCLouvain)

Brussels 1200, Belgium

E-mail: rita.vanbever@uclouvain.be

Dr. F. Morales-Yanez, Dr. M. Dumoulin

Center for Protein Engineering InBIOS

Université de Liège

4000 Liège 1, Belgium

The ORCID identification number(s) for the author(s) of this article can be found under https://doi.org/10.1002/adfm.202101633.

DOI: $10.1002 / \mathrm{adfm} .202101633$ functions that cannot be mimicked by simple chemical compounds. Since the action of proteins is highly specific, they barely interfere with normal biological processes and cause less adverse events. Protein therapeutics are frequently derived from proteins naturally produced by the body. These agents are therefore often well tolerated and poorly immunogenic.

However, proteins also suffer from significant limitations. Proteins with a molecular weight below the threshold for kidney filtration $(67 \mathrm{kDa}$, the size of human serum albumin) are cleared from the systemic circulation within a day. Many proteins are even cleared within a few hours or a few minutes when metabolism contributes to elimination. Therefore, therapeutic proteins need to be injected to patients several times a week (e.g., erythropoietin) or even several times a day (e.g., glucagon-like peptide-1 or GLP-1), resulting in peaks and valleys in plasma concentrations with the alternate risks of systemic side effects and suboptimal therapeutic concentrations. Moreover, frequent administration of medication causes patient discomfort and reduces quality of life. A second limitation of proteins lies in protein immunogenicity. Foreign proteins from prokaryotes or animals might present interesting therapeutic properties in humans. However, intrinsic immunogenicity of nonhuman proteins hampers their therapeutic use in the clinic because specific antibodies generated against the foreign protein neutralize its activity and result in a loss of therapeutic efficacy over time. The unwanted immune response might even cause more serious general immune effects such as anaphylaxis.

Over the last three decades, protein engineering has largely demonstrated that it can provide solutions to the limitations of natural proteins. Breakthroughs in the field led to the development of biobetters, i.e., conjugated or modified proteins with improved properties and modular functions over the original biologic. In particular, since the nineties, dozens of biobetters with an improved pharmacokinetic profile have been approved for clinical use. Adagen, the first biobetter marketed in 1990, is a chemical conjugate between bovine adenosine deaminase and polyethylene glycol (PEG). It is used for enzyme replacement therapy in severe combined immunodeficiency disease associated with a deficiency of adenosine deaminase. The about fifteen PEG chains attached to bovine adenosine deaminase 
decrease its immunogenicity and impart an elimination half-life of 5 days to the protein. This PEGylation strategy has then been applied to many other proteins with the main goal to place protein molecular weight above the threshold for kidney filtration and protect the protein from catabolism, thereby increasing serum half-life. Another major breakthrough has come from the discovery of the FcRn-mediated recycling pathway taken by immunoglobulins $\mathrm{G}$ (IgGs) and serum albumin (SA). IgGs and SA are internalized in endosomes of endothelial cells where they are protected from degradation by binding FcRn. Recycling through FcRn interactions result in the long serum half-lives of IgGs and SA and these serum proteins have been attached to many unrelated therapeutic proteins to increase their half-life. For instance, Albiglutide, marketed in 2013, is a fusion protein between a peptidase-resistant GLP 1 analog and SA. Albiglutide exhibits an extended half-life (5 days) compared with native GLP-1 (3 min). ${ }^{[3]}$

This review will detail the different protein engineering strategies that have been harnessed to extend protein half-life in the systemic circulation. These approaches comprise the preparation of polymer-protein conjugates and the exploitation of the long half-lives of IgGs and SA. In addition to PEGylation, XTENylation, PASylation, and ELPylation have emerged. XTEN, PAS, and ELP are natively disordered polypeptide polymers that have been used as alternatives to PEG. Polypeptide polymers offer the advantages of biodegradability and recombinant production as a single fusion product over PEG. IgG and SA have been used to prolong the half-life of proteins either by fusing the therapeutic protein to an FcRn binding protein (Fc domain of an IgG or SA) or, by conjugating the therapeutic protein to a molecule which noncovalently binds to SA. To end, this review will thoroughly describe the chemical and chemoenzymatic methods used to modify proteins and graft peptide or prosthetic groups to them.

\section{Polymer-Protein Conjugates}

One of the best and widely investigated approaches to prolong serum half-life relies on the conjugation of highly soluble nontoxic polymers to bioactive proteins. ${ }^{[4]}$ Polymer-protein conjugates present an increased hydrodynamic diameter impeding their clearance via kidney glomeruli filtration. Among polymers, PEG has been the first and most used, resulting in the commercialization of more than 15 biobetters (Table 1) and several others are still in clinical development. Yet, to overcome the non-biodegradability property of PEG, polypeptides have recently emerged as alternatives.

\subsection{PEG}

In 1977, Davis and co-workers published a seminal scientific article on the impact of conjugation to PEG on the immunogenicity and blood circulating life of bovine liver catalase. ${ }^{[5]}$ The initial goal of Davis was to minimize or eliminate the immunogenicity of therapeutic enzymes from nonhuman sources by covering antigenic determinants by a linear, flexible, uncharged, and hydrophilic polymer. Thus, bovine liver catalase was randomly conjugated to 1.9 or $5 \mathrm{kDa}$ PEG on its lysine residues. PEGylation of catalase was shown to decrease catalasespecific antibody production following injection in rabbits and to decrease the recognition of the protein by catalase-specific antibodies. The authors additionally observed that PEGylation greatly protected catalase from proteolysis and significantly prolonged its blood half-life in the rabbit.

\subsubsection{The Polymer}

PEG is a linear or branched polyether with hydroxyl end groups and the general structure: $\mathrm{HO}-\left(\mathrm{CH}_{2} \mathrm{CH}_{2} \mathrm{O}\right)_{n}-\mathrm{CH}_{2} \mathrm{CH}_{2}-\mathrm{OH}^{[6]}$ Monomethoxy PEG, mPEG, $\mathrm{CH}_{3} \mathrm{O}-\left(\mathrm{CH}_{2} \mathrm{CH}_{2} \mathrm{O}\right)_{n}-\mathrm{CH}_{2} \mathrm{CH}_{2}-\mathrm{OH}$, is the most used for protein modification because its unique reactive group results in one-site attachment on the protein. PEG can present a wide range of molecular weights and some polydispersity ( $\mathrm{Mw} / \mathrm{Mn}$ is $\approx 1.1$ ), which is a drawback as it leads to undesired polydispersity of the conjugates. PEG is a neutral and amphiphilic polymer. The repeated ethylene moiety along the PEG chain is responsible for the polymer hydrophobicity, whereas the oxygen confers strong interactions with water: three water molecules are bound per monomer unit. Therefore, PEG is soluble in both organic and aqueous media and is highly hydrated. The carbon-carbon and carbon-oxygen bonds offer high flexibility to the whole polymer. The high mobility and hydration of PEG lead to a large and very effective exclusion volume of approaching molecules. Accordingly, the polymer has a hydrodynamic volume five to ten times higher than that of a globular protein of the equivalent molecular weight. ${ }^{[7]}$

\subsubsection{Immunogenicity}

The repeated administration of therapeutic proteins can be highly immunogenic, especially in case of foreign proteins but also in case of human proteins. For instance, Vaisman-Mentesh et al. reported that chimeric monoclonal antibodies exhibited immunogenicity in up to $70 \%$ of patients and fully human monoclonal antibodies in up to $30 \% .{ }^{[8]}$ Protein immunogenicity generates antiprotein antibodies, which can neutralize the therapeutic activity of the protein and cause allergic reactions.

PEGylation is able to decrease the immunogenicity of therapeutic proteins. Accordingly, PEGylation demonstrated a tremendous success and brought to market several proteins of nonhuman origin which might have never reached it as unconjugated versions due to their intrinsic immunogenicity. This is the case of Pegademase and its new recombinant version Elapegademase, Pegasparagase and its new longer-acting version Calasparagase pegol, and Pegvaliase. All these PEGylated proteins are enzymes from either prokaryotes (Escherichia coli) or animals (cow, pig; Table 1). These are mainly used as enzyme replacement therapies in inherited enzyme deficiencies but also as a therapeutic treatment in leukemia.

Asparaginase is a critical component in the treatment of acute lymphoblastic leukemia. ${ }^{[9]}$ Asparaginase hydrolyzes the amino acid L-asparagine to L-aspartic acid and ammonia. L-asparagine is synthesized in most human tissues from 
Table 1. Chronological overview of the FDA-approved PEGylated protein drugs.

\begin{tabular}{|c|c|c|c|c|c|c|c|c|}
\hline $\begin{array}{l}\text { Year of } \\
\text { approval }\end{array}$ & $\begin{array}{c}\text { Commercial } \\
\text { name }\end{array}$ & Generic name & Parent drug & $\begin{array}{l}\text { Protein } \\
\text { size }[\mathrm{kDa} \text { ] }\end{array}$ & $\begin{array}{c}\text { PEG size } \\
\text { and number }\end{array}$ & $\begin{array}{l}\text { Bioconjugation } \\
\text { method }\end{array}$ & $\begin{array}{l}\text { Main site of } \\
\text { attachment }\end{array}$ & Application \\
\hline 1990 & Adagen & Pegademase & $\begin{array}{l}\text { Adenosine } \\
\text { deaminase }\end{array}$ & 40 & $(11-17) \times 5 \mathrm{kDa}$ & NHS ester ligation & Lysines & SCID \\
\hline 1994 & Oncaspar & Pegasparagase & Asparaginase & 31 & $50 \times 5 \mathrm{kDa}$ & NHS ester ligation & Lysines & Leukemia \\
\hline 2000 & PegIntron & Peginterferon- $\alpha-2 b$ & Interferon- $\alpha-2 b$ & 19.2 & $1 \times 12 \mathrm{kDa}$ & Urethane bond & Histidines & Hepatitis C \\
\hline 2001 & Pegasys & Peginterferon- $\alpha$-2a & Interferon- $\alpha-2 \mathrm{a}$ & 19.2 & $1 \times 40 \mathrm{kDa}$ & NHS ester ligation & Lysines & Hepatitis C \\
\hline 2002 & Neulasta & Pegfilgrastim & G-CSF & 18.8 & $1 \times 20 \mathrm{kDa}$ & $\begin{array}{l}\text { Aldehyde } \\
\text { conjugation }\end{array}$ & $\begin{array}{l}\mathrm{N} \text {-terminal } \\
\text { methionine }\end{array}$ & Neutropenia \\
\hline 2003 & Somavert & Pegvisomant & $\begin{array}{l}\text { Human growth } \\
\text { hormone }\end{array}$ & 22 & $(4-6) \times 5 \mathrm{kDa}$ & NHS ester ligation & Lysines & Acromegaly \\
\hline 2007 & Mircera & PEG-EPO & Erythropoietin & 30 & $1 \times 30 \mathrm{kDa}$ & NHS ester ligation & Lysines & Anemia \\
\hline 2008 & Cimzia & $\begin{array}{c}\text { Certolizumab } \\
\text { Pegol }\end{array}$ & anti-TNF $\alpha$ Fab' $^{\prime}$ & 51 & $1 \times 40 \mathrm{kDa}$ & $\begin{array}{l}\text { Maleimide } \\
\text { conjugation }\end{array}$ & $\begin{array}{l}\text { C-terminal } \\
\text { cysteine }\end{array}$ & $\begin{array}{l}\text { RA and Crohn } \\
\text { disease }\end{array}$ \\
\hline 2010 & Krystexxa & Pegloticase ${ }^{a)}$ & Urate oxidase & 34 & $9 \times 10 \mathrm{kDa}$ & $\begin{array}{c}p \text {-Nitrophenyl } \\
\text { carbonate ester } \\
\text { ligation }\end{array}$ & Lysines & Gout \\
\hline 2012 & Omontys & Peginesatide & $\begin{array}{l}\text { Erythropoietin } \\
\text { dimeric peptide }\end{array}$ & 4.9 & $1 \times 40 \mathrm{kDa}$ & NHS ester ligation & $\begin{array}{l}\mathrm{N} \text {-terminal } \\
\text { linker }\end{array}$ & ACKD \\
\hline 2014 & Plegridy & $\begin{array}{l}\text { Peginterferon } \\
\text { beta-1a }\end{array}$ & Interferon $\beta$-1a & 44 & $1 \times 20 \mathrm{kDa}$ & NHS ester ligation & Lysines & $\begin{array}{l}\text { Multiple } \\
\text { sclerosis }\end{array}$ \\
\hline 2016 & Adynovate & $\begin{array}{l}\text { Antihemophilic } \\
\text { pegylated factor }\end{array}$ & $\begin{array}{l}\text { Coagulation } \\
\text { factor VIII }\end{array}$ & 280 & $1 \times 20 \mathrm{kDa}$ & NHS ester ligation & Lysines & Hemophilia A \\
\hline 2017 & Refixia & $\begin{array}{c}\text { Nonacog beta } \\
\text { pegol }\end{array}$ & $\begin{array}{c}\text { Coagulation } \\
\text { factor IX }\end{array}$ & 50 & $1 \times 40 \mathrm{kDa}$ & Glycosylation & $N$-glycans & Hemophilia B \\
\hline 2018 & Asparlas & $\begin{array}{c}\text { Calasparagase } \\
\text { pegol }\end{array}$ & $\begin{array}{l}\text { Asparagine } \\
\text { enzyme }\end{array}$ & 138 & $50 \times 5 \mathrm{kDa}$ & Urethane bond & Lysines & ALL \\
\hline 2018 & Revcovi & Elapegademase & $\begin{array}{l}\text { Adenosine } \\
\text { deaminase }\end{array}$ & 115 & $(11-17) \times 5 \mathrm{kDa}$ & NHS ester ligation & $\begin{array}{c}\text { Alanines and } \\
\text { lysines }\end{array}$ & ADA-SCID \\
\hline 2018 & Jivi & $\begin{array}{c}\text { Damoctocog alfa } \\
\text { pegol }\end{array}$ & $\begin{array}{l}\text { Coagulation } \\
\text { factor VIII }\end{array}$ & 234 & $1 \times 60 \mathrm{kDa}$ & $\begin{array}{l}\text { Maleimide } \\
\text { conjugation }\end{array}$ & Cysteine & Hemophilia A \\
\hline 2018 & Fulphila & Pegfilgrastim-jmdb & G-CSF & 40 & $1 \times 20 \mathrm{kDa}$ & $\begin{array}{l}\text { Aldehyde } \\
\text { conjugation }\end{array}$ & $\begin{array}{l}\mathrm{N} \text {-terminus } \\
\text { methionines }\end{array}$ & Neutropenia \\
\hline 2018 & Palynziq & Pegvaliase & PAL enzyme & 248 & $(28-44) \times 20 \mathrm{kDa}$ & NHS ester ligation & Lysines & Phenylketonuria \\
\hline 2019 & Esperoct & $\begin{array}{c}\text { Turoctocog alfa } \\
\text { pegol }\end{array}$ & $\begin{array}{l}\text { Coagulation } \\
\text { factor VIII }\end{array}$ & 166 & $1 \times 40 \mathrm{kDa}$ & $\begin{array}{c}\mathrm{N} \text {-glycan } \\
\text { engineering }\end{array}$ & O-glycans & Hemophilia A \\
\hline
\end{tabular}

ACKD: anemia associated chronic kidney disease; ADA: adenosine deaminase; ALL: acute lymphoblastic leukemia; AMD: age-mediated macular degeneration; Fab: antigen binding fragment; G-CSF: human granulocyte colony-stimulating factor; NHS: N-hydroxysuccinimide; RA: rheumatoid arthritis; SCID: severe combined immune deficiency; TNF: tumor necrosis factor; VEGF: vascular endothelial growth factor; ${ }^{\text {a) }}$ Market withdrawal in Europe in 2016 for economic reasons.

L-glutamine. However, acute lymphoblastic leukemia cells have very low levels of asparagine synthase and asparagine depletion causes their apoptosis. Asparaginase extracted from E. coli was approved by the FDA in 1978 and then withdrawn in 2012. Hypersensitivity was the most common adverse reaction to E. coli asparaginase and it occurred in up to one third of patients. Pegaspargase has been FDA-approved in 1994 and is the primary form of asparaginase in clinical use today. Pegaspargase shows a rate of allergic reactions of only $10 \%$ in naive patients. ${ }^{[10]}$ PEGylation of asparaginase involves the random attachment of $\approx 50$ PEG chains of $5 \mathrm{kDa}$ to its lysine residues and PEGylation increases asparaginase half-life from $24 \mathrm{~h}$ (unconjugated protein) to 5.5 days (Pegaspargase) and 13.5 days
(Calasparagase pegol). ${ }^{[11]}$ Calaspargase pegol uses the identical enzyme and polyethylene glycol moieties present in Pegaspargase. However, the succinimidyl carbamate linker used in Calaspargase pegol is more hydrolytically stable than the succinimidyl succinate linker used in Pegaspargase which results in a longer half-life.

Pegademase bovine is an adenosine deaminase purified from bovine intestine and conjugated to 11 to 17 chains of $5 \mathrm{kDa}$ PEG. Pegademase does not induce hypersensitivity reactions. However, there have been reports on neutralizing antibodies. In a clinical trial, two out of 17 patients showed an enhanced rate of clearance of plasma adenosine deaminase activity after 4 months of therapy. ${ }^{[12]}$ Enhanced clearance was correlated with 
the appearance of an antibody that directly inhibited both the activity of unmodified adenosine deaminase and pegademase. Patients who previously received pegademase bovine may present antibodies to Elapegademase, a recombinant bovine adenosine deaminase manufactured in E. coli. Therefore, plasma adenosine deaminase activity is monitored in patients for any persistent activity decline.

Pegvaliase is a PEGylated recombinant phenylalanine ammonia lyase derived from the cyanobacterium Anabaena variabilis and expressed in E. coli. Pegvaliase converts phenylalanine to ammonia and trans-cinnamic acid, and is indicated for the treatment of patients with phenylketonuria who have inadequate blood phenylalanine control. Although the enzyme is protected by 28 to 44 PEG chains of $20 \mathrm{kDa}$ each, hypersensitivity reactions have been reported in $75 \%$ of patients treated with Pegvaliase and the acute systemic Type III (immune complex mediated) hypersensitivity reaction has been the most clinically significant and reached $6 \%$ of the patients. All patients treated with Pegvaliase developed a sustained anti-phenylalanine ammonia lyase and anti-PEG IgM and IgG response. Because antibodies bind to the PEG portion of Pegvaliase, binding with other PEGylated therapeutics and increased hypersensitivity to other PEGylated injectables might occur. Neutralizing antibodies capable of inhibiting the enzyme activity were detected in the majority of patients. Patients with higher antibody titers required higher doses to overcome clearance and achieve blood phenylalanine reduction.

The attachment of several small PEG chains to a protein better decreases its immunogenicity than the attachment of one large PEG chain because several PEG chains more widely shield the protein surface. ${ }^{[13]}$ This PEGylation strategy has been followed in all the examples presented above. It is just the opposite approach to the one used to preserve protein activity and only prolongs serum half-life where the conjugation to a unique large PEG chain on the protein side opposite to the active site is sought.

\subsubsection{Prolongation of Serum Half-Life and Residence Time in the Lungs}

PEGylation of fully human proteins aims to increase their serum half-life and thereby increase patient convenience by decreasing administration frequency. The serum half-life of proteins can increase up to 20-fold following PEGylation. For instance, Certolizumab pegol, a Fab antibody fragment conjugated to a 2-armed $40 \mathrm{kDa}$ PEG in C-terminal, exhibits an elimination half-life of 14 days while unconjugated Fab antibody fragments show a half-life of $12-20 h .^{[14]}$ The attachment of a PEG chain to a protein places its molecular weight above the threshold for kidney filtration and reduces renal clearance. In addition, PEG attachment to biopharmaceuticals can protect them from proteolysis. The half-lives of PEGylated protein conjugates increase with the molecular weight of the PEG and with the number of conjugated PEG chains. ${ }^{[15]}$

More recently, PEGylation has been shown to prolong the residence time of protein therapeutics in the lungs and to improve their local therapeutic efficacy in preclinical models of respiratory diseases. ${ }^{[16]}$ PEGylation of recombinant human alpha1-antitrypsine with a $20 \mathrm{kDa}$ PEG sustained the presence of the conjugate in the lungs of mice for $48 \mathrm{~h}$, whereas the nonPEGylated counterpart was cleared within 24 h. ${ }^{[17]}$ Recombinant human alpha1-antitrypsin conjugated to $20 \mathrm{kDa}$ PEG protected mice against human leukocyte elastase-induced lung hemorrhage and the protection was sustained for $72 \mathrm{~h}$. PEGylation of an anti-IL-17A Fab' antibody fragment with 2-armed $40 \mathrm{kDa}$ PEG increased its residence time in the lungs of mice, rats, and rabbits to more than $48 \mathrm{~h}$ while the unconjugated Fab' was cleared from the lungs within $24 \mathrm{~h}^{\left[{ }^{[18]}\right.}$ The prolonged pulmonary residency of the anti-IL-17A PEGylated antibody fragment translated in an improved efficacy in reducing lung inflammation in a murine model of house dust mite-induced lung inflammation. ${ }^{[19]}$ Conjugation of PEG to recombinant human deoxyribonuclease I (rhDNase) resulted in an impressive extension of its residence time ( $\geq 15$ days) in the murine lungs. ${ }^{[20]}$ Moreover, one single dose of PEGylated rhDNase was as effective as 1 daily dose of unconjugated rhDNase during 5 days in decreasing the DNA content in the lungs of $\beta$-ENaC mice, a model of the cystic fibrosis lung disease. The lack of marketed PEGylated proteins for pulmonary delivery reflects the paucity of approved proteins for inhalation in the first place. However, in 2020, Bayer has initiated a phase 2 clinical trial on an inhaled PEGylated peptide (PEGylated adrenomedullin or BAY1097761) for the treatment of acute respiratory distress syndrome (NCT04417036).

Several mechanisms might explain the sustained retention of PEGylated proteins within the lungs. The increase in molecular size decreases the protein transport across the alveolarcapillary barrier toward the systemic circulation. The steric hindrance created by PEG chains on the protein surface prevents proteases from degrading the protein. ${ }^{[21]}$ Finally, the hydrophilic nature of PEG decreases protein interactions with the cell membrane and thereby, decreases protein endocytosis by epithelial cells and alveolar macrophages. ${ }^{[22]}$

\subsubsection{Biological Activity and Impact on Protein Stability}

PEGylation might result in a partial loss of the biological activity of the therapeutic protein. In order to avoid a reduction in biological activity, the PEGylation site should be distant from the active site. Indeed, the active site of the protein may be masked due to the steric hindrance of PEG. Accordingly, site-specific addition of $5 \mathrm{kDa}-\mathrm{PEG}$ to tumor necrosis factor resulted in a $20 \%$ decrease in the activity of the cytokine while random PEGylation led to a $90 \%$ activity loss. ${ }^{[23]}$ In spite of reduced activity, several PEG-protein conjugates for injection are commercially available because of the tremendous increase in serum half-life. For instance, Pegasys (40 kDa PEG-IFN $\alpha 2 \mathrm{a}$ ) only retains $7 \%$ of the wild-type interferon activity and is on the market since 2002. [24]

All marketed PEG-protein conjugates delivered by injection (Table 1) involve a permanent covalent link between the polymer chain and the protein and the PEGylated construct is the active entity. In contrast to conventional permanent PEGylation, a new technology called TransCon is currently developed by Ascendis Pharma where the PEG-protein conjugates are inactive prodrugs. ${ }^{[25]}$ Accordingly, the protein is 
transiently bound to a four-arm $40 \mathrm{kDa}$ PEG and the steric hindrance created by the polymer inactivates the protein. With the hydrolysis of the TransCon linker, the unmodified protein is gradually released in the body. The advantages of this technology are easily highlighted by presenting Ascendis Pharma flagship product, TransCon hGH for which a market authorization application has been submitted. ${ }^{[25]}$ Human growth hormone (hGH) replacement therapy needs to achieve the same tissue distribution and receptor activation as endogenous $\mathrm{hGH}$ because $\mathrm{hGH}$ receptors are in essentially all tissues. Restricted access of protein-enlarged human GH into peripheral tissues led to unexpected outcome such as injection site lipoatrophy and to discontinuation of the development of a permanently-PEGylated hGH. TransCon hGH leverages the known pharmacology and distribution of unmodified hGH with the properties of an inert PEG carrier molecule and avoids imbalances in organ distribution. It allows once-weekly dosing and will ease the lives of patients with hGH deficiency. TransCon PTH and TransCon C-type Natriuretic Peptide are other prodrug therapies in development by Ascendis Pharma. ${ }^{[26]}$

No critical changes to protein secondary and tertiary structures have been noted following PEGylation. ${ }^{[27]}$ PEGylation generally increases the stability of proteins to aggregation. For instance, a Fab' antibody fragment conjugated to two PEG chains of $30 \mathrm{kDa}$ presented higher resistance to protein aggregation than the unconjugated Fab' when exposed to heat and agitation. ${ }^{[28]}$ The steric hindrance created by PEG likely prevents the association of unfolded proteins. However, there are cases where the propensity to aggregation increased. ${ }^{[27 a]}$ The number and size of the PEG chains as well as the type of the conjugation link can affect protein stability. ${ }^{[27 a, 29]}$

\subsubsection{Safety}

Small molecular weight PEGs $(<10 \mathrm{kDa})$ are common excipients in oral, intravenous, nasal, and inhalation formulations. However, larger PEGs (up to $40 \mathrm{kDa}$ ) are used in PEGylated protein therapeutics. PEG is non-biodegradable and its primary clearance mechanism is renal excretion of the intact molecule. Yet, above $30 \mathrm{kDa}-\mathrm{PEG}$, renal ultrafiltration is markedly reduced and liver uptake and excretion through the bile take over. ${ }^{[30]}$

PEG is generally considered to have low toxicity whatever its molecular weight and route of administration. Complement activation and impact on coagulation have been observed at very high PEG concentrations $\left(1-40 \mathrm{mg} \mathrm{mL}^{-1}\right) \cdot{ }^{[31]}$ However, these concentrations are largely exceeding the plasma concentrations reached after injection of PEGylated protein therapeutics that are rather in the $\mathrm{ng} \mathrm{mL}^{-1}$ to $\mu \mathrm{g} \mathrm{mL} \mathrm{m}^{-1}$ range.

Ivens et al. reviewed the preclinical safety data collected on PEGylated protein therapeutics administered by injection currently on the market. ${ }^{[32]}$ Adverse effects observed in preclinical studies were usually related to the pharmacologically active drug component of the molecule, rather than to the PEG moiety. Cellular vacuolation in certain tissues and cell types has been observed for approximately half of the approved PEGylated drugs. Vacuolation was seen most frequently in macrophages. Cytoplasmic vacuolation probably reflects the body's normal response to clear a foreign non-biodegradable body. No functional changes related to PEG for organs and tissues where cellular vacuolation was seen have been reported. Vacuolation was absent below a certain dose of PEG $(0.4 \mu \mathrm{mol} \mathrm{kg}-1$ per month) and it has been observed for PEG molecular weight of at least $30 \mathrm{kDa}$. Vacuolation was reversible provided sufficient recovery time was allowed.

PEG has been considered as a nonantigenic and nonimmunogenic component. However, a number of reports have documented the presence of anti-PEG antibodies, such as IgG and IgM, following repeated injections of PEGylated proteins in the clinic (see above). The generation of anti-PEG antibodies is favored when the protein moiety is highly immunogenic. AntiPEG antibodies were also found in $20 \%$ to $25 \%$ of 350 healthy blood donors who have not received PEGylated biopharmaceuticals. ${ }^{[7]}$ Everyday use compounds such as cosmetics, food or household chemicals contain PEG and this might explain the occurrence of anti-PEG antibodies in a subset of the population. However, the neutralizing character of these anti-PEG antibodies has not been demonstrated. It should be noted that other neutral soluble polymers such as polyvinylpyrrolidone have been shown to decrease exogenous proteins immunogenicity but that PEG decreased it the most and generated the weakest antipolymer antibody response. ${ }^{[33]}$

\subsection{Polypeptides}

Polypeptide polymers have been introduced in the hope of overcoming the limitations of PEG which suffers from several drawbacks including non-biodegradability and thereby possible risk of accumulation in cells and tissues, and generation of antibodies against PEG and PEGylated proteins. ${ }^{[34]}$

Similar to PEG, the action of polypeptides primarily relies on decreasing the clearance via increasing the hydrodynamic volume of the proteins they are fused to, but also on their shielding from proteolytic degradation, detection by the host immune system, and receptor-mediated clearance. ${ }^{[35]}$ Yet, these polypeptides have not been used to decrease the immunogenicity of foreign proteins as PEG has and, up to now, their use has been limited to prolonging the serum half-life of human proteins. Polypeptides can be easily fused, via genetic engineering, to recombinant proteins and peptides. They are hydrophilic, stable, reportedly nonimmunogenic, biodegradable, tuneable, do not alter the expression of proteins in bacterial systems, have large hydrodynamic volume thereby increasing the half-life of fused protein partners. ${ }^{[34 b, 35,36]}$ The two main polypeptides currently in active development are XTEN and PAS. HAPylation is the process of fusing a repeated sequence of a glycine-rich polypeptide; this strategy was developed by Schlapschy et al. for anti-HER2 Fab before discovering PAS but it is no longer pursued. ${ }^{[37]}$

\subsubsection{XTEN}

XTEN (loosely referred to as recombinant PEG) is genetically fused polypeptides composed of nonrepetitive randomized segments of six chemically stable amino acids: alanine (A), glutamate $(E)$, glycine $(G)$, proline $(P)$, serine $(S)$, and threonine 
Table 2. XTEN-protein conjugates in clinical development.

\begin{tabular}{lcccccc}
\hline Name & Phase & Status & Protein conjugate & XTEN MW or aa number & Application & Ref. \\
\hline VRS-859 & II & C & Exenatide-XTEN & $\approx 80$ kDa (864 aa) & Type 2 diabetes & [40a] \\
BIVV001 & III & R & rFVIIIFc-VWF-XTEN & Two XTENs: 288 and 144 aa & Severe hemophilia A & NCT04161495 \\
BIVV001 & I/II & C & rFVIIIFc-VWF-XTEN & & Severe hemophilia A & NCT03205163 \\
BIVV001 & III & N & rFVIIIFc-VWF-XTEN & & Severe hemophilia A & NCT04644575 \\
Somavaratan (VRS-317) & II & T & hGH-XTEN & Two XTENs: $83.6 \mathrm{kDa}$ & AGHD & NCT02719990 \\
Somavaratan (VRS-317) & II & C & hGH-XTEN & $13.3 \mathrm{kDa}$ & AGHD & NCT02526420 \\
Somavaratan (VRS-3017) & III & C & hCH-XTEN & & PGHD & NCT02339090 \\
\hline
\end{tabular}

AA: amino acid; AGHD: adult growth hormone deficiency; C: completed; N: not yet recruiting; NCT: number clinical trial; PGDH: pediatric growth hormone deficiency; R: recruiting; rFVIIIFc-VWF: recombinant coagulation Factor VIII Fc-von Willebrand factor; T: terminated.

(T) ${ }^{[38]}$ The selection of these amino acids is based on the idea of avoiding amino acids that might affect the solubility, activity, or stability of proteins. Therefore, positively charged amino acids (known to bind to the cell membrane) and amide-containing residues (could alter the stability of proteins) were excluded.[38] In addition, glycine and proline have a low propensity to form secondary structures and provide a disordered conformation to XTEN.

XTEN can be expressed in E. coli system $\left(>8 \mathrm{mg} \mathrm{g}^{-1}\right.$ wet-cell weight), making its production easy and cheap. Furthermore, the XTEN polypeptide length can easily be tuned, and the resulting conjugates are completely degradable into short peptides or amino acids. The proof-of-concept of XTEN using exenatide (GLP-1 receptor agonist, an antidiabetic peptide) demonstrated that the $84 \mathrm{kDa}$-fused exenatide-XTEN is thermostable (up to $75{ }^{\circ} \mathrm{C}$ ), has a large hydrodynamic radius and does not induce immunogenicity in mice. ${ }^{[38]}$ Besides, exenatide-XTEN significantly improved the pharmacokinetics of the peptide by extending its half-life 65,71 , or 125 -fold in rats, mice, or monkeys, respectively. Other peptides and proteins have been successfully XTENylated, such as glucagon, green fluorescent protein (GFP), factor VII, human growth hormone ( $\mathrm{hGH}$ ), teduglutide, a recombinant human Glucagon-like peptide 2 (GLP2-2G), annexin 5A, T-20 (antiretroviral peptide), and clotting factor IX. ${ }^{[38,39]}$

The encouraging in vivo results of XTEN fusion proteins have advanced three XTEN-conjugated proteins to clinical trials (Table 2). In phase I clinical trial, exenatide-XTEN (VRS-859) showed promising results in the glycemic control in patients suffering from type 2 diabetes mellitus. ${ }^{[35]}$ The long half-life of $\approx 5$ days of exenatide-XTEN versus $2.4 \mathrm{~h}$ for unconjugated exenatide highlights the potential of a monthly administration. Somavaratan (VRS-317) is a novel long-acting hGH for the treatment of hGH deficiency in children and adults. ${ }^{[40]}$ Despite the 12 -fold reduced potency of Somavaratan in vitro compared with $\mathrm{hGH}$, the increased half-life of up to 60 -fold resulted in an overall improved efficacy in vivo. ${ }^{[40 b]}$ Somavaratan demonstrated clinically significant improvements in the growth (height velocity and IGF-1) of prepubertal children in phase I clinical trials (NCT01718041). Adverse events following Somavaratan administration were similar to daily growth hormone in pediatric growth hormone deficiency and neutralizing antibodies were reported in 2 of the 64 children involved. ${ }^{[25,40 \mathrm{~b}]}$ However, twice-monthly SC injections of Somavaratan failed to meet the primary endpoint of noninferiority compared to daily $\mathrm{SC}$ injection of reference drug rhGH (Genotropin) in phase III VELOCITY clinical trials in children (NCT02339090), leading to the termination of phase II trials in adults (NCT02719990).

More promising results have been obtained in phase II clinical trials for the treatment of hemophilia A with BIVV001, a rFVIIIFc-VWF-XTEN construct (XTENylated recombinant coagulation Factor VIII Fc-von Willebrand Factor) (NCT03205163). BIVV001 was shown to be safe and to have a superior PK compared with the recombinant factor VIII. ${ }^{[41]}$ In humans, a 3 to 4-fold increase in the half-life (9.1 to $37.6 \mathrm{~h}$ and 13.2 to $42.5 \mathrm{~h}$ for low and high doses, respectively) and up to a 7-fold increase in area under the curve were recorded compared with the recombinant factor VIII. ${ }^{[41 a]}$ Clinical trials have progressed to phase III to evaluate the long-term safety and efficacy of weekly administration of BIVV001 in previously treated patients with severe hemophilia A (NCT04644575 and NCT04161495).

XTENylation is also investigated in the field of anticancer therapeutics. ${ }^{[42]}$ In particular, Amunix Pharmaceuticals develops XTEN-improved T-cell engagers to address some of their limitations in the treatment of solid tumors due to on-target offtumor toxicity. ${ }^{[43]}$ T-cell engagers are bispecific antibodies binding a target antigen on a tumor cell on one side and a CD3 on a T-cell on the other side to promote tumor cell apoptosis via the activation of the immune reaction. XTENylated proteaseactivated T-cell engagers (XPATs) can prolong the half-life and reduce off-target cytotoxicity induced by nonspecific $\mathrm{T}$ cell activation (up to 15000 -fold). Once XTEN chains are cleaved by proteases in the tumor microenvironment, highly potent T-cell engagers are released. This strategy was used to target cancer cells-expressing HER2 or EGFR. Both generated XPATs have a strong safety profile in cynomolgus monkeys (no cytokine release syndrome or systemic activation of T cells at high doses) and tumor regressions in murine tumor xenograft models. ${ }^{[42]}$

\subsubsection{PAS}

PASylation, introduced by XL-protein $\mathrm{GmbH}$, is conceptually similar to XTENylation. However, it uses only three uncharged amino acids, namely, proline $(\mathrm{P})$, alanine $(\mathrm{A})$, and serine $(\mathrm{S})$. The uncharged nature of PAS residues and their disordered conformation confers to PAS biophysical properties similar to 
those of PEG. ${ }^{[34 a]}$ PAS is biodegradable, hydrophilic, and reportedly nonimmunogenic; its random coil conformation contributes to the expansion of the hydrodynamic volume, thereby increasing the serum half-life of the fused proteins. ${ }^{[34 b, 44]}$

PAS was reported to be efficiently produced in bacterial systems as well as in eukaryotic cells with precise control over the composition of the sequence and its length. This latter spans from 100 to 1200 residues; PAS comprising 200 (18 kDa), 400 $(35 \mathrm{kDa})$, and $600(50 \mathrm{kDa})$ residues are however the most frequently used. ${ }^{[34 a, 44]}$ Pioneering work by Schlapschy and coworkers demonstrated the feasibility and usefulness of PASylation in improving the PK properties (half-life and area under the curve) of anti-HER2 Fab fragment (trastuzumab, $48 \mathrm{kDa}$ ), human interferon $\alpha 2 \mathrm{~b}(21 \mathrm{kDa})$, and hGH $(22 \mathrm{kDa})$. Upon conjugation to PAS of 600 residues, the apparent molecular size of these proteins increased 22, 26, or 27-fold, respectively, translating into serum half-lives 21, 29, or 94-fold longer in mice compared with the unmodified proteins. ${ }^{[34 a]}$ Serum antibodies against the hGH or interferon moieties were detectable in mice. However, there was no cross-reactivity with unrelated proteins fused to PAS, indicating that the PAS polypeptide itself did not exhibit immunogenicity in these studies. Since the original publication by Schlapschy et al., the same group and others have applied this strategy to more than a dozen proteins. The list includes IFN $\beta$ superagonist YNS $\alpha 8$, IFN- $\beta 1$ b, IFN $\alpha$, leptin and leptin antagonist, humanized anti-CD20 and anti-HER2 Fabs, coversin, erythropoietin (EPO), clotting factor VIII, uricase, exendin, IL-1Ra, Certolizumab Fab, anti-VEGFA nanobody, and Designed Ankyrin Repeat Protein (DARPin) anti-EpCAM (epithelial cell adhesion molecule), FluoroCalins anti ED-B, and VEGFR-3. ${ }^{[4,45]}$ The increased hydrodynamic radius of the PASylated proteins improved their serum half-life by a factor of at least 10 in mice without compromising the biological activity of the fused proteins. ${ }^{[44]}$ An increase in the biological activity (twofold) was reported for PASylated IFN- $\beta 1 \mathrm{~b} .{ }^{[45 \mathrm{~b}]}$

Most of the applications of PAS are for therapeutic proteins and are still in the preclinical stage. However, PASylation was shown to be valuable for in vivo imaging through extending the serum half-life of radiolabeled tracers allowing a better uptake in the tumor. For instance, $\mathrm{PAS}_{200}$ human CD98hcED-specific anticalin labeled with zirconium-89 was used for PET imaging of mice bearing-prostate cancer or B-cell lymphoma subcutanenous xenografts expressing the CD98 antigen. ${ }^{[46]}$ Likewise, sensitive PET imaging of thyroid cancer was achieved using ${ }^{89} \mathrm{Zr}$-Dfo-PAS ${ }_{200}$-Gal3 Fab, a chimeric antigen-binding fragment directed against human Galectin-3 (Gal3 expressed in malignant thyroid nodules). The tracer accumulates selectively in the tumor-bearing thyroid lobe of xenograft mice giving strong contrast images $24 \mathrm{~h}$ postinjection. ${ }^{[47]}$

A first in-human study has been recently published for the imaging of HER2-positive metastatic breast cancer. ${ }^{[48]}$ PAS-Fabs can be tailored to obtain a good compromise between the long half-life of full mAbs (which have major issues such as high toxicity due to slow clearance or low tumor penetration) and the short half-lives of Fab fragments limiting their accumulation in the tumor. An anti HER2-Fab was PASylated with PAS200 then radiolabeled with zirconium-89. PET imaging using ${ }^{89} \mathrm{Zr}$-Dfo-PAS ${ }_{200}$-HER2 Fab construct was thereby successful, well-tolerated, and represents a potential tool for diagnostic of
HER2-positive breast cancer in patients. ${ }^{[48]}$ The slower clearance from the blood allowed the accumulation of the tracer in both the primary tumor and metastases located in axillary lymph nodes at $24 \mathrm{~h}$ postinjection. However, the radiotracer was unsuccessful in detecting tumor metastases in the brain.

PASylation has also been exploited in the targeted delivery of small drugs and nucleic acids. ${ }^{[44]}$ Falvo et al. have developed doxorubicin-loaded nanocage using PAS-modified ferritin protein nanocarrier (HFt-PAS). ${ }^{[49]}$ Human ferritin (HFt) binds the transferrin receptor upregulated in many cancer cells. The modification of ferritin heavy chains with PAS of 40 or 75 residues (HFt-PAS 40 and HFt-PAS ${ }_{75}$, respectively) resulted in highly soluble and stable HFt-PAS nanocages with higher doxorubicin loading capacity (threefold) compared with HFt. The half-life was also up to 5-fold longer in mouse blood compared with HFt and 56-fold longer compared with free doxorubicin. ${ }^{[9]}$ The introduction of matrix metalloproteinase cleavable linker (MP) between the ferritin units and the PAS tags (HFt-MP-PAS) allowed targeting tumors more selectively by taking advantage of the high concentrations of matrix metalloproteinases in the tumor microenvironment. ${ }^{[50]}$ This strategy was four- and eight times more efficient than doxorubicin-albumin conjugate (Aldoxorubicin) and free doxorubicin in treating mice bearing xenogeneic PaCa-44 pancreatic tumor. ${ }^{[50]}$ The authors inserted two glutamate residues in the PAS sequence to prevent nanocages aggregation by electrostatic repulsion of the negative surface charges. The new construct, termed HFt-MP-PASE, was shown to improve further the solubility and monodispersity of the nanocages. ${ }^{[1]}$ Similarly, Tesarova et al. successfully encapsulated the cytostatic alkaloid ellipticine (Elli) in the cavity of PAS-modified ferritin with PAS of 10 residues (PAS ${ }_{10}$-FRTElli). PAS 10 -FRTElli exhibited a better accumulation in tumor tissue of mice bearing triple-negative breast cancer (MDA-MB-231) xenograft compared to free drug or FRTElli. ${ }^{[52]}$ The higher accumulation of PAS $_{10}$-FRTElli in tumor tissue, likely due to the prolonged circulation time and EPR effect, was nonetheless no better than in free Elli or FRTElli in reducing the initial volume of the tumor.

XTEN and PAS of equivalent lengths (300, 600, 900 residues) were shown to increase the half-life of DARPin Ec1 (a DARPin targeting epithelial cell adhesion molecule EpCAM) to the same extent (up to 114-fold). ${ }^{[53]}$ DARPins (designed ankyrin repeats) are made of several 33-amino acid residue modules with alphahelical structure engineered to bind a targeted protein with high specificity and affinity. ${ }^{[54]}$ Interestingly, the charge difference between the two polymers had no effect on the biodistribution, clearance, or tumor accumulation of the fused protein in a xenograft model in mice. When cytotoxic maleimidocaproyl monomethyl auristatin $\mathrm{F}$ was conjugated, the largest DARPin (PAS 900 residues) did not have the highest anti-tumor response despite having the most prolonged half-life. The highest antitumor response was induced by intermediate size and half-life conjugates. Authors ascribed this interesting result to the balance between serum half-life and diffusion within the tumor.

\subsection{3. $E L P$}

Elastin-like polypeptide (ELP) is a polymer constituted from randomly repeated motifs of valine $(\mathrm{V})$, proline $(P)$, glycine $(G)$, 
$\mathrm{X}$, and $\mathrm{G}$ where $\mathrm{X}$ represents any amino acid except proline. ${ }^{[55]}$ ELPs are good candidates for conjugation as they are biocompatible and biodegradable due to their high similarity with elastin. ${ }^{[5,56]}$ An additional attractive property of ELPs is that they exhibit a thermally responsive reversible phase transition: when the temperature is increased above the phase transition temperature, ELPs transition from a soluble state to a gel-like state. The size and composition of ELP sequence can be tuned to aim a transition temperature below the physiological temperature; thus, once injected, soluble ELPs at room temperature form a subcutaneous depot at body temperature and slowly release the drug into the circulation. ${ }^{[57]}$ Beside sustained-release properties of ELPs, the half-life of ELP-fused proteins is also extended by increasing their hydrodynamic radius. ${ }^{[57,58]}$

Conrad et al. successfully fused an anti-TNF nanobody (VHH) to ELP resulting in an active construct with a half-life 24-fold longer than that of the non-ELPylated anti-TNF VHH in mice after IV injection (28 $\mathrm{min}$ to $11.4 \mathrm{~h}) .{ }^{[59]}$ Other ELPyated therapeutics are being developed primarily by PhaseBio (phasebio.com), taking advantage of the dual mechanism of the sustained release of subcutaneous depots and extended circulation time of ELP fused proteins. Three products are currently in clinical trials for weekly subcutaneous injections. ${ }^{[42,58]}$ Glymera (PB1023), an ELP-GLP-1 (phase IIb, NCT01658501, now licensed to ImmunoForge, Co. Ltd) and PE0139, an ELP-insulin (phase 2a, NCT02581657), both in type 2 diabetes patients. PB1046, an ELP-VIP (vasoactive intestinal peptide), is in phase II clinical trial for pulmonary arterial hypertension (Pemziviptadil, NCT03556020 and NCT03795428) and COVID-19 patients with acute respiratory distress syndrome (NCT04433546). However, this latter indication is no longer pursued.

\section{Fusion of Therapeutic Proteins to Serum Proteins}

The abundance of IgGs and albumin in blood and their long serum half-life make them ideal tools for engineering therapeutic protein constructs with extended circulation time. SA is the most abundant protein in blood with a concentration of $45 \mathrm{~g} \mathrm{~L}^{-1}$. The blood concentration of IgGs reaches $10 \mathrm{~g} \mathrm{~L}^{-1}$. While IgGs have a serum half-life of 21 days, SA has a halflife of 19 days. Therefore, IgGs and SA have been used to prolong the half-life of protein therapeutics in two strategies: i) by directly fusing the therapeutic protein to an FcRn binding region of IgG or to SA or ii) by fusing the therapeutic protein to a molecule (e.g., a peptide, a protein or a fatty acid) able to noncovalently bind IgG or SA.

\subsection{FcRn Recycling}

FcRn (neonatal Fc receptor or Brambell receptor) is a heterodimer receptor widely expressed in mammalian cells including the endothelium, intestinal and respiratory epithelia, and macrophages. It is derived from the major histocompatibility complex class I receptor and comprises a transmembrane $\alpha$-chain of $45 \mathrm{kDa}$ with a $17 \mathrm{kDa} \beta$-2 macroglobulin chain involved in the folding, transport and FcRn functions.
FCRn extends the half-life of IgG and SA by protecting them from degradation. IgG is internalized in endothelial cells by pinocytosis and is then found in the recycling endosome. The binding between IgG and FcRn is dependent on the acidic $\mathrm{pH}$ $(<6.5)$ of endosomes. It involves the $\alpha 2$ and $\beta 2$ domains of FcRn and $\mathrm{pH}$-dependent salt bridges mediated by two histidine residues located between $\mathrm{CH} 2$ and $\mathrm{CH} 3$ of the Fc domain. At physiological or higher $\mathrm{pH}$, FcRn does not interact with those ligands (Figure 1). Acidity in vesicles allows the strong binding of IgG to the endosomal FCRn, protection from endosomal degradation and translocation of IgG back to the cell surface, where they are released at the neutral $\mathrm{pH}$ (7.4) of blood. SA is internalized through macropinocytosis, mostly in macrophages; it binds the FcRn-at the opposite site that binds the Fc-by involving a histidine residue, then it follows the same recycling pathway as IgG. ${ }^{[60]}$ While FcRn binding prolongs the serum half-life of IgG and SA, the nonrecycled molecules or antibodies, as for example, IgE or IgA, are transported to the lysosome for degradation.

It is interesting to note that the IgG subclass influences the interaction with $\mathrm{FcRn}$. IgGs comprise four subclasses, $\operatorname{IgG}_{1}$, $\mathrm{IgG}_{2}, \mathrm{IgG}_{3}$, and $\mathrm{IgG}_{4}$ differing in their constant $\mathrm{C}_{\mathrm{H} 2}$ domain and binding properties (Table 3). ${ }^{[61]}$ The choice of the most appropriate subclass depends on the desired half-life since the $\mathrm{C}_{\mathrm{H} 2}$ region is involved in binding to IgG-Fc receptors. ${ }^{[61,62]}$ While the subclasses $\operatorname{IgG}_{1}, \operatorname{IgG}_{2}$, and $\operatorname{IgG}_{4}$ possess a high binding affinity for $\mathrm{FcRn}$, the $\operatorname{IgG}_{3}$ isotype lacks a functional FcRn binding domain resulting in a shorter half-life compared to the other isotypes. ${ }^{[63]}$ The non-FcRn recycling IgG $_{3}$ can represent an asset for therapies involving mAbs as carriers for cytotoxic payloads-due to their short half-life limiting hematologic off-target toxicity.

Protein engineering strategies have been developed to increase the affinity of human IgG1 for FcRn in order to further increase its recycling and thus to obtain therapeutic antibodies with an even longer half-life. ${ }^{[64]}$ MedImmune technology consists in inserting mutations in the $\mathrm{CH}_{2}$ domain of the $\mathrm{Fc}$ region of $\mathrm{IgG}_{1}$, for instance, a triple substitution (M252Y, S254T, and T256E), referred as YTE (Patent US7658921B2). Proof-of-concept on palivizumab showed an in vitro tenfold increase in binding affinity to human FcRn at low $\mathrm{pH}$ with an efficient release at $\mathrm{pH}$ 7.4. ${ }^{[65]}$ Further experiments with palivizumab and several YTE variants of IgGs exhibited an increased plasma half-life for up to three months. ${ }^{[66]}$ Recently, YTE introduced in neutralizing HIV mAbs has been assessed in macaques infected with HIV. While the YTE sequence improved the PK profile following IV administration, it also induced immunogenicity, an issue limiting its clinical transfer for now.

One last characteristic of the Fc fragment is its immunoregulatory properties. IgG or Fc-fusion proteins bound to the FcRn are diverted from antigen presentation compartments, obviating an immune response. The Fc is also able to enhance the suppressive activity of T-cells (Treg) involved in the maintenance of immunologic self-tolerance. ${ }^{[67]}$ Two T-cells epitopes have been identified in the Fc region of $\operatorname{IgG}_{1}$ that are capable of regulating immunogenicity by activating Tregs. Consequently, in addition to extending protein half-life, the Fc-fusion strategy also represents the potential to reduce immunogenicity. 


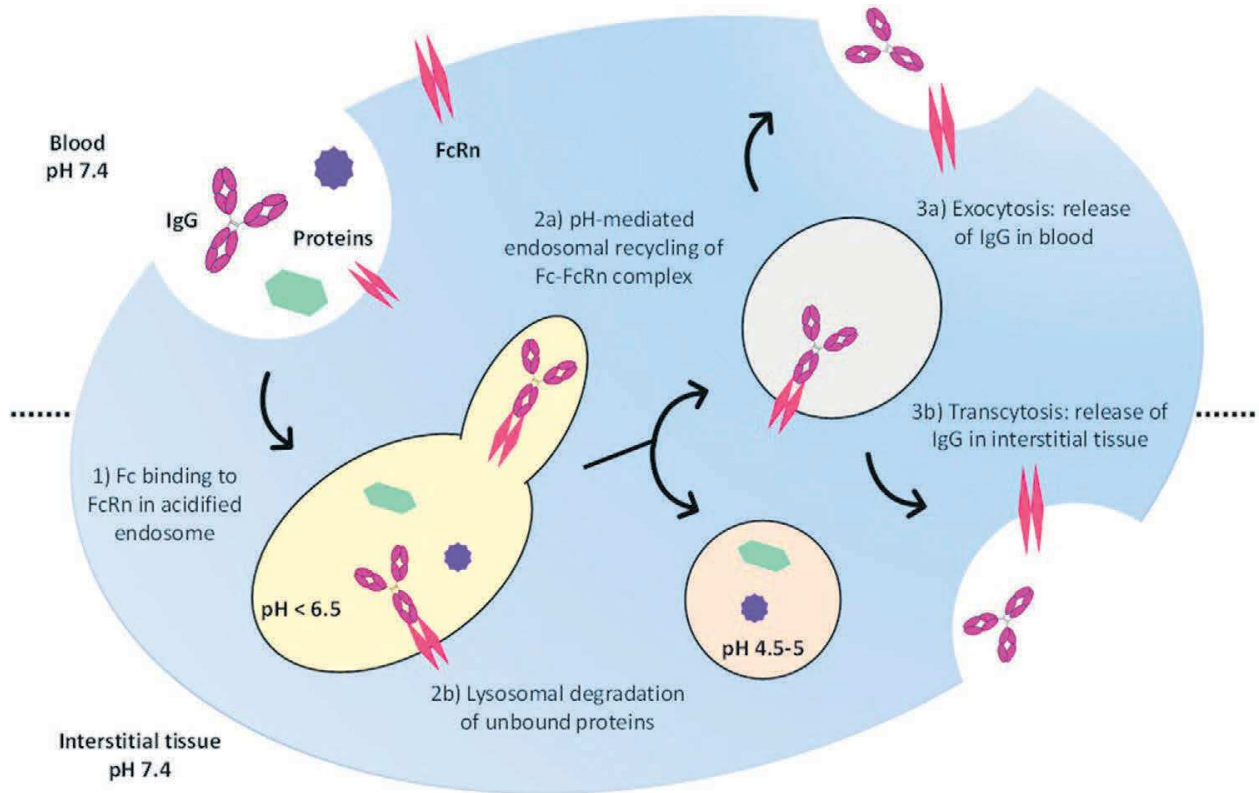

Figure 1. FcRn-mediated recycling pathway after pinocytosis of serum IgG. The IgG is first internalized into the cell via endocytosis. Acidity in vesicles allows the binding to FcRn while unbound plasma proteins undergo lysosomal degradation. The FcRn-bound IgG is then translocated back to the cell surface. Due to neutral $\mathrm{pH}$, the complex dissociates and the IgC is released in the blood after exocytosis or in interstitial tissue via transcytosis. The $\mathrm{FcRn}$ is then free to be involved in another cycle.

\subsection{Fc-Fusion Proteins}

In most cases, Fc-fusion proteins present an extended half-life compared with their parent protein or peptide. Most of the Fcfusion proteins are produced by genetic engineering via the fusion of the C-terminus of the biological payload to the N-terminus of the Fc resulting in a stable Fc-conjugate. ${ }^{[58]}$ Currently, four groups of proteins or peptides are used for Fc-fusion partners, namely, the extracellular domains of natural receptors (e.g., etanercept, alefacept, etc.), cytokines (e.g., aflibercept), peptides (e.g., romiplostim, dulaglutide), and enzymes (e.g., asfotase $\alpha$, turoctocog $\alpha$, etc.) as shown in Table $4 .^{[62]}$ Etanercept is the first Fc-fusion protein, approved in 1998, for the treatment of rheumatoid arthritis. Etanercept is constructed by two $75 \mathrm{kDa}$-human TNFRII exodomain each linked to the FC of a human $\operatorname{IgG}_{1}$ (Table 4). ${ }^{[68]}$ Due to the fusion to the Fc domain, etanercept is eliminated slowly in patients, with a half-life of 70-100 h. It binds TNF- $\alpha$ and TNF- $\beta$ with higher affinity than

Table 3. Main properties of human IgG subclasses.

\begin{tabular}{lcccc}
\hline & $\operatorname{lgG}_{1}$ & $\operatorname{lgG}_{2}$ & $\operatorname{lgG}_{3}$ & $\operatorname{lgG}_{4}$ \\
\hline Average MW [kDa] & 146 & 146 & 165 & 146 \\
Mean adult serum level $\left[\mathrm{g} \mathrm{L}^{-1}\right]$ & 9 & 3 & 1 & 0.5 \\
Relative abundance [\%] & 60 & 32 & 4 & 4 \\
Half-life [days] & 21 & 20 & 7 & 21 \\
Clq binding & ++ & + & +++ & - \\
FcyRI $\left[K_{\mathrm{D}}, \mathrm{nm}\right]$ & 10 & No aff. & 10 & 1 \\
FcRn $\left[K_{\mathrm{D}}, \mathrm{nM}\right]$ & 20 & 20 & 0 & 80 \\
\hline
\end{tabular}

Clq: complement lq system; Fc 2 RI: Fc gamma receptor I; MW: molecular weight. No aff.: No affinity. Data from Murphy and Weaver. ${ }^{[6]]}$ the endogenous TNF receptor, thereby preventing the proinflammatory cascade. ${ }^{[68]}$

Another good example of Fc-fusion protein is the well-established standard treatment for patients with hemophilia A: the factor VIII (FVIII). ${ }^{[69]}$ Several strategies have been employed to extend the half-life of rFVIII products, including PEGylation, XTENylation, and Fc fusion. ${ }^{[70]}$ Recombinant FVIII FCfusion protein (rFVIIIFc), constructed by fusion of a single molecule of rFVIII to the Fc region of a human IgG1, has been the first FVIII approved with an extended half-life (Eloctate, Table 4). ${ }^{[41 c, 71]}$ However, compared with the conventional rFVIII, the fused rFVIIIFc has a half-life only 1.5-fold longer (19.0 vs $12.4 \mathrm{~h}$ ) and a slightly slower systemic clearance (2.0 vs $\left.3.0 \mathrm{~mL} \mathrm{~h}^{-1} \mathrm{~kg}^{-1}\right)$. ${ }^{[72]}$

\subsection{Targeting Serum Albumin}

Serum albumin, the most abundant protein in blood, is characterized by a long serum half-life and a broad tissue distribution. The long serum half-life of SA is due to: i) its large size (i.e., $67 \mathrm{kDa}, 585$ amino acids spanning three independently folding domains) which is higher than the cut-off for kidney filtration, and ii) more importantly to its protection from intracellular lysosomal degradation via its binding to the FcRn (Figure 1). The binding of the therapeutic protein to SA (directly or indirectly) may further protect it by shielding it from proteolytic degradation. Along with this, SA exhibits a high capacity to extravasate from the bloodstream to reach the lymphatic system and thus it accumulates in cancerous or inflamed areas. ${ }^{[73]}$ SA therefore constitutes a target of choice to which therapeutic proteins have been paired through mainly two different approaches in order to increase their serum half-life. 
Table 4. Chronological overview of FDA-approved chimeric Fc-fusion proteins: structural characteristics, mechanisms of action, and main applications.

\begin{tabular}{|c|c|c|c|c|c|c|c|}
\hline $\begin{array}{l}\text { FDA } \\
\text { approval }\end{array}$ & $\begin{array}{l}\text { Generic name } \\
\text { (US trade name) }\end{array}$ & $\begin{array}{l}\mathrm{MW} \\
{[\mathrm{kDa}]}\end{array}$ & Target & Protein format & $\begin{array}{l}\text { Half-life } \\
\text { [days] }\end{array}$ & Mechanism of action & Main application \\
\hline 1998 & $\begin{array}{l}\text { Etanercept } \\
\text { (Enbrel) }\end{array}$ & 150 & TNF- $\alpha$ & $\begin{array}{l}\text { P75 TNFR exodomain } \\
\text { lgG1 Fc fusion }\end{array}$ & 2.8 & $\begin{array}{l}\text { Blocks TNF- } \alpha / \text { TNFR } \\
\text { interaction }\end{array}$ & Rheumatoid arthritis \\
\hline 2003 & $\begin{array}{l}\text { Alefacept } \\
\text { (Amevive) }\end{array}$ & 92 & CD2 & $\begin{array}{l}\text { CD58 (LFA-3) } \\
\text { IgG1 Fc fusion }\end{array}$ & 11 & $\begin{array}{l}\text { Blocks interaction of } \\
\text { CD2 with LFA } \\
\text { Inhibits T-cell activation }\end{array}$ & $\begin{array}{l}\text { Moderate-severe } \\
\text { psoriasis }\end{array}$ \\
\hline 2005 & $\begin{array}{l}\text { Abatacept } \\
\text { (Orencia) }\end{array}$ & 92 & CD80/CD86 & $\begin{array}{c}\text { CTLA-4 } \\
\text { IgG1 Fc fusion }\end{array}$ & $12-23$ & $\begin{array}{l}\text { Blocks T-cell activation } \\
\text { and cytokine production }\end{array}$ & Rheumatoid arthritis \\
\hline 2008 & $\begin{array}{l}\text { Rilonacept } \\
\text { (Arcalyst) }\end{array}$ & 251 & $\begin{array}{l}\text { ILIA, ILIB, } \\
\text { ILIRN }\end{array}$ & $\begin{array}{l}\text { IL-IR1 and IL-IRAcP } \\
\text { IgG1 Fc fusion }\end{array}$ & 8.6 & $\begin{array}{l}\text { Blocks IL-1 } \beta \text { signaling, } \\
\text { reduces inflammation }\end{array}$ & $\begin{array}{l}\text { Cryopyrin-associated } \\
\text { periodic syndrome }\end{array}$ \\
\hline 2008 & $\begin{array}{l}\text { Romiplostim } \\
\text { (Nplate) }\end{array}$ & 60 & $\begin{array}{c}\text { Thrombopoietin } \\
\text { R (agonist) }\end{array}$ & $\begin{array}{l}\text { Peptibody } \\
\text { IgG } 1 \text { Fc fusion }\end{array}$ & 3.5 & $\begin{array}{l}\text { Stimulates JAK2 et } \\
\text { STAT5 pathways }\end{array}$ & $\begin{array}{l}\text { Chronic immune } \\
\text { thrombocytopenia }\end{array}$ \\
\hline 2011 & $\begin{array}{l}\text { Belatacept } \\
\text { (Nulojix) }\end{array}$ & 90 & $\mathrm{CD} 80 / \mathrm{CD} 86$ & $\begin{array}{c}\text { CTLA-4 } \\
\operatorname{lgG1~Fc~fusion~}\end{array}$ & $\approx 8-10$ & $\begin{array}{l}\text { Blocks T-cell activation } \\
\text { and cytokine production }\end{array}$ & $\begin{array}{l}\text { Prophylaxis after } \\
\text { kidney transplant }\end{array}$ \\
\hline 2011 & Aflibercept (Eylea) & 115 & VEGF-A & $\begin{array}{l}\text { VEGFR } 1 \text { and } 2 \\
\text { IgG1 Fc fusion }\end{array}$ & $\approx 5-7$ & Inhibits angiogenesis & $\begin{array}{c}\text { Age-related macular } \\
\text { degeneration }\end{array}$ \\
\hline 2012 & $\begin{array}{l}\text { Ziv-Aflibercept } \\
\text { (Zaltrap) }\end{array}$ & 115 & VEGF-A & $\begin{array}{l}\text { VEGFR } 1 \text { and } 2 \\
\text { IgGl Fc fusion }\end{array}$ & $\approx 5-7$ & Inhibits angiogenesis & $\begin{array}{c}\text { Metastatic } \\
\text { colorectal cancer }\end{array}$ \\
\hline 2013 & $\begin{array}{l}\text { Turoctocog alfa } \\
\text { (NovoEight) }\end{array}$ & 166 & Factor substitute & $\begin{array}{l}\text { Truncated rhfactor VIII } \\
\text { IgGl Fc fusion }\end{array}$ & $\approx 0.4$ & $\begin{array}{c}\text { Replaces factor VIII } \\
\text { deficit }\end{array}$ & Hemophilia A \\
\hline 2014 & $\begin{array}{l}\text { Eftrenonacog alfa } \\
\text { (Alprolix) }\end{array}$ & 98 & Factor substitute & $\begin{array}{l}\text { Monomeric factor IX } \\
\operatorname{lgGl} \mathrm{Fc} \text { fusion }\end{array}$ & $\approx 3$ & Replaces factor IX & Hemophilia B \\
\hline 2014 & $\begin{array}{c}\text { Efmoroctocog alfa } \\
\text { (Eloctate) }\end{array}$ & 170 & Factor substitute & $\begin{array}{l}\text { Monomeric factor VIII } \\
\text { IgGl Fc fusion }\end{array}$ & 0.8 & Replaces factor VIII & Hemophilia A \\
\hline 2014 & $\begin{array}{l}\text { Dulaglutide } \\
\text { (Trulicity) }\end{array}$ & 60 & $\begin{array}{l}\text { GLP-1R } \\
\text { (agonist) }\end{array}$ & $\begin{array}{l}\text { GLP-1 analog } \\
\text { IgC4 Fc fusion }\end{array}$ & 3.75 & $\begin{array}{l}\text { Stimulates insulin } \\
\text { production }\end{array}$ & Type 2 diabetes \\
\hline 2015 & $\begin{array}{l}\text { Asfotase alfa } \\
\text { (Strensiq) }\end{array}$ & 180 & Factor substitute & $\begin{array}{l}\text { Human TNS-ALP } \\
\text { IgGl Fc fusion }\end{array}$ & $\approx 5$ & Replaces deficient ALP & Hyphosphatasia \\
\hline 2016 & $\begin{array}{c}\text { Etanercept-szzs } \\
\text { (Erelzi) }\end{array}$ & 125 & TNF- $\alpha$ & $\begin{array}{l}\text { Dimeric TNFR } \\
\text { IgGl Fc fusion }\end{array}$ & 2.8 & $\begin{array}{l}\text { Blocks TNF- } \alpha / \text { TNFR } \\
\text { interaction }\end{array}$ & Rheumatoid arthritis \\
\hline 2018 & $\begin{array}{c}\text { Damoctocog alfa } \\
\text { pegol } \\
\text { (Jivi) }\end{array}$ & 230 & Factor substitute & $\begin{array}{l}\text { Monomeric factor } \\
\text { VIII-PEG } \\
\text { IgGI Fc fusion }\end{array}$ & 0.8 & Replaces factor VIII & Hemophilia A \\
\hline 2019 & $\begin{array}{l}\text { Turoctocog alfa } \\
\text { pegol } \\
\text { (Esperoct) }\end{array}$ & 206 & Factor substitute & $\begin{array}{l}\text { Truncated factor } \\
\text { VIII-PEG } \\
\text { IgGI Fc fusion }\end{array}$ & 0.8 & Replaces factor VIII & Hemophilia A \\
\hline 2019 & $\begin{array}{l}\text { Luspatercept-aamt } \\
\text { (Reblozyl) }\end{array}$ & 76 & TGF- $\beta$ & $\begin{array}{l}\text { Activin RIIB } \\
\text { IgGl Fc fusion }\end{array}$ & 11 & Blocks TGF- $\beta$ signaling & $\begin{array}{l}\text { Beta thalassemia } \\
\text { anemia }\end{array}$ \\
\hline
\end{tabular}

ALP: alkaline phosphatase; CTLA-4: cytotoxic T lymphocyte-associated antigen 4; FDA: Food and Drug Administration; GLP: glucagon-like protein; IgG: immunoglobulin G; IL: interleukin; JAK2: Janus kinase 2; LFA: lymphocyte function associated antigen; MW: molecular weight; PEG: polyethylene glycol; R: receptor; STAT5: signal transducer and activator of transcription 5; TGF: transforming growth factor; TNF: tumor necrosis factor; TNS: tissue nonspecific; VEGF: vascular endothelial growth factor.

\subsubsection{Covalent Conjugation of Therapeutic Peptides and Proteins to Serum Albumin}

In a first approach, the therapeutic peptide or protein is covalently linked to SA. The advantages of this approach, also referred to as albumination, are that $\mathrm{SA}$, which is one of the best characterized proteins in the pharmaceutical field, is not immunogenic and has an excellent biocompatibility and degradability. ${ }^{[7]}$ Moreover, this nonglycosylated protein, can be produced in large amounts in eukaryotic cells such as yeast or mammalian cells, alone or fused to therapeutic proteins. ${ }^{[75]}$
SA was approved by the FDA as a therapeutic protein in 1982 which reduces the regulation considerations for the development of new SA-based therapeutics.

Two albuminated proteins have entered the market. In the first one, Albiglutide used for treatment of type 2 diabetes, SA is fused to GLP-1; while in the second, Albutrepenoncogalpha used to treat haemophilia, it is fused to recombinant coagulation factor IX. These fusion proteins are injected subcutaneously or intravenously, once weekly or up to once every other week, respectively. At least three other SA-fusion proteins have entered clinical trials (Table 5). 
Table 5. Genetically engineered serum albumin fusion proteins in the market or clinical trials

\begin{tabular}{|c|c|c|c|c|c|c|}
\hline Trade name & Generic name & Parent drug & Position on SA & $\begin{array}{c}\text { Construct molecular } \\
\text { weight }[k D a]\end{array}$ & Application & Status \\
\hline Albuferon/Zalbin/Joulefon & Albinterferon & Interpheron alpha2 & $\mathrm{N}$-terminus & 85.7 & Chronic hepatitis C & NCT00964665a) \\
\hline Eperzan/Tanzeum & Albiglutide & GLP-1 & C-terminus & 72.9 & Diabetes mellitus type II & FDA approval in 2014 \\
\hline Neugranin, Egranli & Balugrastim & hG-CSF & $\mathrm{N}$-terminus & 85 & $\begin{array}{c}\text { Chemotherapy-induced } \\
\text { neutropenia }\end{array}$ & $\begin{array}{l}\text { Positive evaluation } \\
\text { by EMA in 2014 }\end{array}$ \\
\hline Idelvion & Albutrepenonacog alfa & Coagulation factor IX & C-terminus & 125 & Hemophilia B & FDA approval in 2016 \\
\hline CSL689 & NA & Recombinant factor VIIa & C-terminus & 120 & Hemophilia A or B & NCT02484638 \\
\hline
\end{tabular}

EMA: European Medicines Agency; FDA: Food and Drug Administration; GLP-1R: Glucagon-like peptide 1. hGCSF: human granulocyte colony stimulating factor. SA: serum

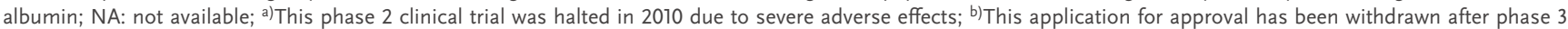
for commercial reasons.

A number of factors affect the magnitude of half-life extension conferred by the fusion to SA including the affinity of SA for FcRn at neutral and acidic pHs, the size and nature of the therapeutic protein, and the site of attachment of the therapeutic protein on SA. In any case, the effects of the conjugation/fusion to SA on the binding, the stability, the therapeutic effects, the biodistribution and pharmacokinetics of a given therapeutic protein have to be evaluated to choose the best configuration.

In order to study the influence of the affinity of SA to FcRn, a number of mutational variants of SA with modified affinity for FCRn have been engineered. ${ }^{[76]}$ For example, the replacement of Lys-573 with any amino acid resulted in enhanced binding to FcRn at acidic $\mathrm{pH}$ while minimally affecting the binding at neutral $\mathrm{pH}$. In particular, the affinity of the variant $\mathrm{K} 573 \mathrm{P}$ for human FcRn is more than 12-fold that of the wild type (WT) SA $\left(10.3 \times 10^{-9}\right.$ vs $\left.125.6 \times 10^{-9} \mathrm{M}\right)$, resulting in extended serum half-life in WT-mice, mice transgenic for human FcRn, and cynomolgus monkeys (5.4 to $8.8 \mathrm{~d}$ ). ${ }^{[76 a]}$ Very recently, the same research group has generated a triple mutant, E505Q/ T527M/K573P (QMP-SA) of SA which can be expressed in similar amount than the WT-SA while its affinity for human FcRn is increased by about 160-fold. In mice, the half-time of QMP-SA fused to Factor VIIa (FVIIa) and administrated intravenously, is almost 4-fold longer compared with the WT-SA fusion, without compromising the therapeutic properties of FVIIa. This enhanced efficiency can be rationalized by the fact that, compared to WT-SA fusion proteins, the higher affinity of the mutational variants of SA give them a competitive advantage over the endogenous SA for FcRn binding. ${ }^{[76 b]}$ Moreover, since the attachment of large cargo to SA often reduces the affinity of SA for FcRn, the use of engineered SA variants with improved affinity allows maintaining an affinity of the fusion protein above that of unmodified WT-SA. ${ }^{[77]}$ The availability of a series of mutational variants of SA with different affinities constitutes an opportunity for optimizing the drug efficiency, tolerability and dosing by finely tuning the serum half-life of the therapeutic protein. ${ }^{[76 a]}$

The large size of SA may shield the therapeutic protein fused to it. Although the shielding can be beneficial to protect the therapeutic peptide or protein from proteolysis, it may also have detrimental effects on its functional properties. In order to reduce this eventual shielding effects, therapeutic proteins can be fused to the SA domain III $(23 \mathrm{kDa})$, which is both necessary and sufficient for FcRn binding in a pH-dependent manner (Figure 2). Serum albumin domain III and mutational variants thereof have been fused for example to an ScFv and resulted in an improved half-life (i.e., up to $56.7 \mathrm{~h}$ vs 2.9 for the $\mathrm{ScFv}$ alone).$^{[78]}$ Reducing the size of the SA moiety was also shown to ensure a better tumor accumulation of the therapeutic protein..$^{78]}$

SA or its derivatives (i.e., mutational variants) can be conjugated to a therapeutic protein via different approaches. First, it can be site-selectively chemically coupled via its free cysteine residue at position 34 located in domain I and distant from the FcRn interface (Figure 2), via maleimide coupling. Recently, Bak et al. first labeled the cysteine 34 with a DBCO function that was further conjugated to a therapeutic peptide equipped with a clickable non-natural amino acid-p-azido-1-phenyalanine $(\mathrm{AzF})$ through strain-promoted azide-alkyne cycloaddition

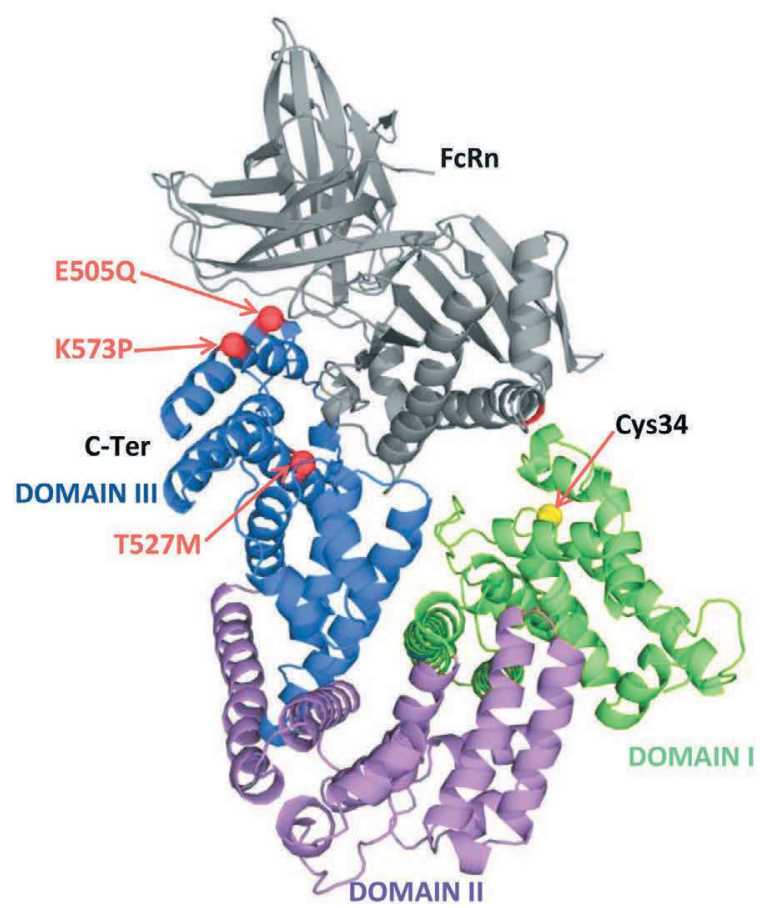

Figure 2. Structure of SA in complex with FcRn. The three structural domains are highlighted as well as the position of the mutations discussed in the text and the free Cys34 (PDB 4K71). 
Table 6. Comparison of the different approaches to extend the serum half-life of proteins via targeting serum albumin (SA).

\begin{tabular}{|c|c|c|c|c|}
\hline Design & Molecule engaged & Advantages & Drawbacks & $\begin{array}{l}\text { Site-specific } \\
\text { conjugation }\end{array}$ \\
\hline \multirow[t]{2}{*}{$\begin{array}{l}\text { Genetic or } \\
\text { chemical fusion } \\
\text { to albumin }\end{array}$} & $\begin{array}{l}\text { Full-length albumin } \\
\text { (and mutational } \\
\text { variants thereof) }\end{array}$ & $\begin{array}{l}\text { Tunable effects via mutations } \\
\text { Reduced regulatory considerations } \\
\text { (nonimmunogenic, biodegradable) } \\
\text { Easy production }\end{array}$ & $\begin{array}{l}\text { Shielding of the } \\
\text { therapeutic protein }\end{array}$ & Yes \\
\hline & Albumin domains & $\begin{array}{c}\text { Reduced size } \\
\text { Tunable effects via mutations } \\
\text { Lower shielding effect } \\
\text { Better tissue penetration } \\
\text { Easy production }\end{array}$ & & Yes \\
\hline \multirow[t]{4}{*}{$\begin{array}{l}\text { Noncovalent } \\
\text { binding to } \\
\text { albumin }\end{array}$} & Fatty acids & Low cost, biocompatibility & $\begin{array}{c}\text { Poor solubility } \\
\text { Lower affinity for SA } \\
\text { Immunogenicity of the linker }\end{array}$ & No/Yes \\
\hline & Bacterial ABD & $\begin{array}{c}\text { Small size } \\
\text { Tunable PK } \\
\text { Easy production, high stability }\end{array}$ & Immunogenicity & Yes \\
\hline & $\begin{array}{l}\text { Antibody fragments } \\
\text { (Fab, scFv, Fv, VH, VL, } \\
\text { nanobody, and VNAR) }\end{array}$ & $\begin{array}{c}\text { Small size } \\
\text { Tunable PK } \\
\text { Easy production }\end{array}$ & $\begin{array}{l}\text { Immunogenicity if not from } \\
\text { human Abs }\end{array}$ & Yes \\
\hline & $\begin{array}{c}\text { Artificial proteins } \\
\text { (DARPIn and Aptide) }\end{array}$ & $\begin{array}{c}\text { Small size } \\
\text { Tunable PK } \\
\text { Easy production }\end{array}$ & Immunogenicity & Yes \\
\hline
\end{tabular}

ABD: albumin binding domain

(SPAAC). ${ }^{[79]}$ This approach was used to conjugate GLP-1 to SA at three different site-specific positions. Although, the half-life, in mice, of the three conjugated peptides was similar (i.e., $8 \mathrm{~h}$ compared to $3 \mathrm{~min}$ for the nonconjugated peptide), the potency of the peptide significantly depended on the site of conjugation. ${ }^{[79]}$ We anticipate that in the future, further development of site-specific-bioorthogonal labeling will enable to increase the potency of albuminated pharmaceuticals. Finally, SA and its derivatives can be genetically fused to the therapeutic protein either at the C-terminus, $\mathrm{N}$-terminus or both; and the chimeric proteins are expressed in the suitable host as a single polypeptide. ${ }^{[80]}$

\subsubsection{Noncovalent Binding of Therapeutic Proteins to Serum Albumin}

The second approach consists in fusing or conjugating the therapeutic protein to molecules which bind to endogenous SA (Table 6). These later can be molecules that naturally bind SA (e.g., fatty acids or bacterial albumin binding domains, ABDs), and proteins specifically engineered to bind SA.

Natural Binders of Serum Albumin: Fatty acids. SA acts as a transporter of fatty acids (7 binding sites for long fatty acids and 2 for medium-size fatty acids). Thus, the conjugation of peptide or protein to fatty acids, referred to as lipidation, allows to extend their serum half-life and a series of lipidated peptides and proteins are on the market (Table 7). For example, the serum half-life of an insulin analog (desB30 human insulin) is increased from 4-6 $\min$ to $5-7 \mathrm{~h}$ by conjugating it to myristic acid (C14) through the $\mathrm{N} \varepsilon$-amine of LysB29. This lipidated insulin, called Detemir, was approved in 2004 and the extension of half-life makes it suitable for a once-daily subcutaneous injection. ${ }^{[81]}$ The prolongation of the blood half-life is due to a combination of two phenomena: the interaction of the C14 moiety with the fatty acid binding site on albumin and the prolongation of absorption via the oligomerization of the lipidated insulin. Indeed, the myristic acid is thought to stabilize both a hexamer-dihexamer equilibrium and hexamer-albumin complexes in the subcutis. Such complexes are likely to protract insulin absorption into the bloodstream. Then, upon dissociation and absorption into the bloodstream, the insulin Detemir monomers can bind albumin through their fatty acid; more than $95 \%$ of circulating insulin Detemir is indeed albumin bound. Other examples of lipidated biopharmaceuticals are Liraglutide and Semaglitude. Liraglutide is a GPL-1 analog in which the lysine 34 has been mutated to an arginine, allowing its site-specific conjugation to palmitic acid through the $\mathrm{N} \varepsilon$ amine of Lys 26 via a $\gamma \mathrm{Glu}$ spacer. Liraglutide, which was approved in 2010, has a half-life of 8-10 and 13-15 h following IV and SC injection, respectively. Such half-life extension makes it suitable for once daily administration. ${ }^{\left[{ }^{[2]}\right.}$ Semaglutide consists in GPL-1 with two amino acid substitutions at positions 8 and 34, where alanine and lysine are replaced by 2 -aminoisobutyric acid and arginine, respectively. The additional mutation on A8 improves GLP-1 potency. Semaglutide is conjugated to a C-18 fatty diacid (stearic acid) on the lysine 26. Its serum half-life is about 7 days and once-weekly injection is therefore enough. ${ }^{[82]}$ While the first three commercialized lipidated biopharmaceuticals are peptides or small proteins, Somapacitan which has been recently approved by the FDA is derived from a larger protein, hGH (22 kDa, $191 \mathrm{aa})$. The leucine at position 101 of hGH is mutated to a cysteine residue that is used to conjugate a C16 fatty acid through a tetrazole linker by alkylation. Somapacitan long half-life allows a weekly injection for the treatment of adults with hGH deficiency. ${ }^{[83]}$ 
Table 7. Serum albumin-targeting proteins in clinical trials or in the market.

\begin{tabular}{|c|c|c|c|c|c|c|}
\hline $\begin{array}{l}\text { Trade } \\
\text { name }\end{array}$ & Generic name & Parent drug & $\begin{array}{l}\text { Molecular } \\
\text { weight }[k D a]\end{array}$ & Conjugation reaction & Application & Status \\
\hline Levemir & Insulin detemir & Human insulin & 5.9 & Myristic acid on lysine at position B29 & Diabetes mellitus I/II & $\begin{array}{l}\text { FDA approval } \\
\text { in } 2005\end{array}$ \\
\hline Tresiba & $\begin{array}{l}\text { Insulin } \\
\text { degludec }\end{array}$ & Human insulin & 5.9 & $\begin{array}{l}\text { Hexadecanedioic acid on lysine } \\
\text { at position B29 }\end{array}$ & Diabetes mellitus I/II & $\begin{array}{l}\text { FDA approval } \\
\text { in } 2015\end{array}$ \\
\hline $\begin{array}{l}\text { Victoza/ } \\
\text { Saxenda }\end{array}$ & Liraglutide & GPLP-1R (L27R) & 3.7 & Palmitic acid on lysine at position 26 & Type II diabetes & $\begin{array}{l}\text { FDA approval } \\
\text { in } 2010\end{array}$ \\
\hline $\begin{array}{l}\text { Ozempic/ } \\
\text { Rybelsus }\end{array}$ & Semaglutide & $\begin{array}{l}\text { GPLP-1R (A8-aminoisobutyric } \\
\text { acid, L34R) }\end{array}$ & 3.7 & Stearic diacid $(\mathrm{C} 18)$ on lysine at position 26 & Type II diabetes & $\begin{array}{l}\text { FDA approval } \\
\text { in } 2017\end{array}$ \\
\hline Sogroya & Somapacitan & $\begin{array}{l}\text { Human growth hormone } \\
\qquad(\mathrm{hGH})(\mathrm{L} 101 \mathrm{C})\end{array}$ & 23.3 & $\mathrm{C} 16$ on position $\mathrm{C} 101$ & $\begin{array}{l}\text { Adults with growth } \\
\text { hormone deficiency }\end{array}$ & $\begin{array}{l}\text { FDA approval } \\
\text { in } 2020\end{array}$ \\
\hline NA & $\begin{array}{l}\text { GSK2374697 } \\
\text { (AlbudAb) }\end{array}$ & Exendin-4 & 16 & $\begin{array}{l}\text { Fusion of antibody albumin binding } \\
\text { domain to exendin } 4\end{array}$ & Obesity & NCT02829307 \\
\hline Izokibep & $\begin{array}{l}\text { ABY-035 or } \\
\text { IMG-020 }\end{array}$ & & & Two affibodies anti-II-17 and one ABD & $\begin{array}{c}\text { Multiple autoimmune } \\
\text { diseases }\end{array}$ & NCT04713072 \\
\hline NA & Vobrarilizumab & & 26 & $\begin{array}{l}\text { Bispecific nanobody anti-II6 and anti-SA } \\
\text { domain }\end{array}$ & RA & NCT02101073 \\
\hline NA & $\begin{array}{l}\text { Ozoralizumab } \\
\text { (ATN103) }\end{array}$ & & 45 & $\begin{array}{l}\text { Trivalent bispecific nanobody anti-TNF- } \alpha \\
\text { and anti-SA domain }\end{array}$ & RA & $\begin{array}{l}\text { NCT01007175 } \\
\text { NCT04077567 }\end{array}$ \\
\hline NA & $\begin{array}{l}\text { Sonelokimab } \\
\text { (M1095) }\end{array}$ & & & $\begin{array}{l}\text { Trispecifc nanobody antihuman interleukin } \\
\text { (IL)-17A, IL-17F, and anti-SA }\end{array}$ & Plaque psoriasis & NCT03384745 \\
\hline NA & M6495 & & 28.1 & $\begin{array}{c}\text { Bisepcific nanobody anti-ADAMTS-5 and } \\
\text { anti-SA }\end{array}$ & Osteoarthritis & $\begin{array}{l}\text { NCT03224702 } \\
\text { NCT03583346 }\end{array}$ \\
\hline NA & B1655088 & & & $\begin{array}{l}\text { Bispecific nanobody antichemokine } \\
\text { receptor } C X 3 C R 1 \text { and anti-SA }\end{array}$ & Atherosclerosis & NCT02696616 \\
\hline NA & MP250 & & & $\begin{array}{c}\text { Trispecific DARPin, anti-VEGF, ani-HGF, } \\
\text { and anti-SA }\end{array}$ & Multiple myeloma & $\begin{array}{l}\text { NCT03418532 } \\
\text { NCT03136653 }\end{array}$ \\
\hline
\end{tabular}

FDA: Food and Drug Administration; hrPCA: hormone refractory prostate cancer; GLPIR: glucagon-like peptide 1 receptor. NA: not available. RA: rheumatoid arthritis.

The advantages of lipidation are that the fatty acids are cheap to synthesize, biocompatible and nonimmunogenic. However, the main drawbacks are the insolubility of fatty acids and their lower affinity for SA than for example antibodies and fragments thereof. ${ }^{\left[{ }^{[4]}\right.}$ Moreover, the linker might be immunogenic. An immunogenic response against lipidated biopharmaceuticals has indeed been reported. The levels of antibodies generated were however low and without clinical relevance. ${ }^{[81]}$

A number of factors affect the magnitude of half-life extension conferred by the conjugation to fatty acids including the length of the fatty acid and of the linker used to conjugate it to the protein and the size of the therapeutic protein. For lipidated GPL-1, a clear positive correlation between the length of fatty acids and the affinity for SA was observed; however, this was associated with a decreased potency of GPL-1 probably because only GLP-1 not bound to SA can bind to the receptor. Therefore, a compromise should be made between these two parameters. ${ }^{[85]}$

Fatty acids can be conjugated to peptides and proteins via the lysines. However, this usually results in heterogenous labeling and loss of therapeutic efficacy. Site-specific conjugation via copper-catalyzed azide-alkyne cycloaddition and SPAAC has been reported. ${ }^{[86]}$ For example, in the latter case, a clickable non-natural amino acid, p-azido-L-phenylalanine $(A z F)$ is introduced to a specific site of the target peptide or protein; then a fatty acid analog containing dibenzoclyclootyne group (DBCO-FA) is conjugated to AzF site of the target peptide/protein via SPAAC. ${ }^{[87]}$ Such a protocol was used to site-specifically conjugate urate oxidase, a therapeutic protein for the treatment of tumour lysis syndrome, to palmitic acid at two positions. The conjugation resulted in high SA binding capacity and retained enzyme activity. Fu et al. have developed a strategy, through the genetic encoding of $\varepsilon$-Nheptanoyl-1-lysine (HepoK), allowing the introduction of a fatty-acid-conjugated amino acid into proteins with exquisite site-specificity and homogeneity. Using this approach, they produce a HepoK-incorporated GLP1 in E. coli which showed a more potent and long-lasting ability in decreasing blood glucose level in mice than WT GLP1. ${ }^{[88]}$

Although lipidation is effective in prolonging the blood half-life of peptides or small proteins (MW $<28 \mathrm{kDa}$ ), it is less efficient to increase the half-life of larger proteins. Such proteins, when conjugated to fatty acids, are thought to compromise the binding of SA to FcRn due to the fact that the dominant fatty acid-binding sites partially overlap with the FcRn binding site. ${ }^{[89]}$ For such large proteins, it was recently shown that increasing the linker length between the fatty acid and the target protein reduces the steric hindrance for the binding of FcRn to SA and results in longer serum half-life. For example, there is a linear correlation between the linker length (from 0.25 up to $2.8 \mathrm{~nm}$ ) and the serum half-life of urate oxidase $(140 \mathrm{kDa})$, a therapeutic protein used to treat hyperuricemia, conjugated to palmitic acid. The longer linker led to a sevenfold 
greater extension of serum half-life in mice. ${ }^{[89]}$ Such a correlation was not observed for small proteins. ${ }^{[84]}$

Bacterial Serum Albumin Binding Domains (ABDs): The second class of SA naturally binding molecules are the bacterial proteins targeting SA including Staphylococcus protein A and Streptococcus protein G. ${ }^{[90]}$ The SA binding domains of these proteins, composed of about 50 amino acids $(\approx 5 \mathrm{kDa})$ have been extensively engineered to further improve their halflife extension capability by a combination of combinatorial protein engineering, in vitro selection via phage display technology and rational design, leading to the selection of fentomolar affinity binders or of minimal size binders. ${ }^{[91]}$ For example, Guo et al. have fused an ABD to a human epidermal growth factor receptor 2 (HER2)-specific immunotoxin ZHER2-PE38. ${ }^{[92]}$ Compared with nonfused ZHER2-PE38, this new construct exhibited a clearly increased serum half-life (331 vs $13 \mathrm{~min}$, $\approx 25$-fold extension) and remarkably improved antitumor effects in an NCI-N87 subcutaneous xenograft model. The Albumod platform developed by Affibody $\mathrm{AB}$ to improve the $\mathrm{PK}$ of biologics is based on such ABDs. Izokibep (also known as IMG020 or ABY-035) is a bispecific fusion protein made of two affibodies (i.e., $6.5 \mathrm{kDa}$ artificial proteins derived from the $\mathrm{Z}$ domain of staphylococcal Protein A and structured as a triple $\alpha$-helix bundle) with a high affinity for interleukin-17A (IL-17A) and one ABD domain $(5 \mathrm{kDa})$ with high affinity for SA. ${ }^{[3]}$ It is in clinical trial to treat patients with ankylosing spondylitis (Table 7).

The advantages of ABD are their small size, high stability, easiness to be engineered and to be produced recombinantly. Their drawback is their potential immunogenicity since they derive from bacterial sources.

Non-Natural Binders of Serum Albumin: Finally, a number of proteins specifically binding SA have been generated. This includes various antibody fragments as well as artificial proteins (i.e., aptides and DARPins). ${ }^{[94]}$

Antibody Fragments: A series of antibody fragments targeting SA have been generated including Fab, Fv, ScFv, VH, VL derived from conventional IgG essentially from human, murine or rabbit origin, and VNAR and nanobodies which are derived from heavy-chain only antibodies. ${ }^{[14,95]}$ These later two are produced by sharks and camelids, respectively; they are devoid of light chains. Their binding site is therefore constituted by a single $\operatorname{IgG}$ domain referred to as $\mathrm{VHH}$ or nanobody when derived from camelid and VNAR when derived from sharks. ${ }^{[96]}$ Nanobodies are more and more used in various fields including human medicine imaging and therapy. ${ }^{[97]}$ Despite their small size, nanobodies bind to their antigen with a high affinity. Due to their small size, they have a number of unique favorable properties including high stability, high solubility, easiness to be further engineered to adapt their properties to a given application and to create multidomain constructs, easiness to produce and store, low immunogenicity due to the high sequence identity $(\approx 80 \%)$ with the human VH3 (variable domain of the heavy-chain of conventional antibodies) gene family and easiness to be humanized if necessary, ability to target unusual epitopes and capacity to work intracellularly. ${ }^{[96,98]}$ In February 2019, Caplacizumab, the first nanobody-derived drug, was approved by the FDA for acquired thrombotic thrombocytopenic purpura, a rare disease characterized by excessive blood clotting in small blood vessels. It consists in two identical nanobodies targeting the A1 domain of von Willebrand factor, linked by a linker made of three alanines.

A number of anti-SA nanobodies have been described; they extend the serum half-life of the protein they are fused to up to 376-fold in preclinical models. ${ }^{[99]}$ Five nanobodies-based biopharmaceuticals involving a SA-binding moiety are in clinical trials (Table 7): Vobrarilizumab and Ozoralizumab to treat rheumatoid arthritis, M6495 to treat osteoarthritis, BI5508 to treat atherosclerosis and Sonelokimab to treat psoriasis. Vobrarilizumab consists in a bispecific nanobody targeting respectively IL6 and SA, and Ozoralizumab is a trivalent bispecific nanobody with two nanobodies targeting TNF- $\alpha$ and one targeting SA. ${ }^{[100,101]}$ Sonelokimab (also known as M1095) is a trispecific nanobody; it is made of nanobodies specific to human IL-17A, IL-17F, and SA. M6495 is a bispecifc nanobody made of one anti-ADAMTS5 protease (a disintegrin and metalloprotease with thrombospondin-motifs-5) nanobody and one nanobody anti-SA. In vitro, M6495 completely inhibits ADAMTS5 which is involved in arthritic diseases. In an 8-week murine destabilization of the medial meniscus model, it slowed progression of joint damage when administered prophylactically. Finally, a bispecific nanobody binding to both SA and the chemokine receptor CX3CR1, referred to BI65088, is a potent antagonist to CX3CR1 that significantly inhibits plaque progression in a murine model of atherosclerosis. ${ }^{[102]}$ After IV in cynomolgus monkey, its blood half-life was 9.2 days. To reduce immunogenicity, the sequence of the nanobodies have been humanized. ${ }^{[103]}$

Most of the anti-SA antibody fragments have been derived from immune librairies made from the blood of animals, essentially rabbits, mice, and lamas immunized with the target protein. ${ }^{[14,95 a]}$ Binders specific of SA can then be selected from these libraries by a panning strategy such as phage display. Inclusion of endogenous SA-binders during this procedure favors the selection of binders that will not interfere with the function of SA including the binding to FcRn. Moreover, the selection of binders that cross react with SA from different origins (e.g., mouse, rat, monkey, and human) can be carried out by alternatively using one of these proteins as target in the consecutive rounds of selection. ${ }^{[95 a]}$ A combination of one round of phage display panning and next-generation DNA sequencing has also been used to identify cross-reactive nanobodies against SA. ${ }^{[95 a]}$

One critical point with such nonhuman anti-SA antibody fragments is their potential immunogenicity. Thus, they should be humanized and, for conventional antibody fragments, this is usually carried out by complementary determining region grafting onto human VH and VL frameworks. ${ }^{[14]}$ Given their single-domain character, nanobodies can be easily humanized by mutating key residues in the sequence of their framework and various strategies to efficiently humanise nanobodies without significantly affecting their binding specificity, stability, and solubility have been established. ${ }^{955,104]}$

Note that an alternative strategy to increase the serum halflife of nanobodies, due to the easiness with which they can be used as building blocks, is to fuse them to a subunit of a multimeric protein. Fan et al. have, for example, generated a platform they named fenobody, in which a nanobody developed 
against H5N1 virus is displayed on the surface of ferritin in the form of a 24mer. This overall affinity of the fenobody for H5N1 was drastically increased (i.e., by a factor 360) and its serum half-life in a murine model was extended by a factor $10 \mathrm{com}$ pared to the monovalent nanobody counterpart. ${ }^{[105]}$

The AlbudAb platform which is based on a drug fusion with a variable heavy or light chain domain derived from a human IgG that exhibits high albumin affinity was developed by GlaxoSmithKline. GSK2374697, a genetically engineered fusion protein of such a human domain antibody fragment to exendin-4 acts as a long-duration GLP-1 receptor agonist for the treatment of type 2 diabetes. The pharmacokinetic profile was prolonged, with estimated half-lives ranging from 6 to 10 days in humans (vs $2.5 \mathrm{~h}$ for exendin-4 alone). ${ }^{[106]}$

Artificial Proteins: Several artificial proteins designed by combinatorial protein engineering have been selected against SA including DARPins and Aptides. MP0250 is a multidomain protein consisting in four DARPin domains with the following successive specificities within a single polypeptide chain: SA, vascular endothelial factor-A, hepatocyte growth factor, and SA. ${ }^{107]}$ This multidomain protein is in clinical phase 2 for the treatment of patients with solid tumors MP0250 specifically inhibits both vascular endothelial growth factor (VEGF) and hepatocyte growth factor (HGF) with the aim of disrupting the tumour microenvironment in patients with solid tumours. Its serum half-life is about 2 weeks. ${ }^{[108]}$ Thus, a dosing interval of 2, 3 or even 4 weeks can be envisioned. Aptides are structure-constrained peptides containing a randomizable binding region and a constant $\beta$-hairpin scaffold. An anti-SA aptide with $\mathrm{K}_{\mathrm{D}}$ of $188 \times 10^{-9} \mathrm{M}$ was isolated by phage display and fused to exenatide. The serum half-life of the fusion protein was fourfold longer compared with exenatide alone. ${ }^{[94 \mathrm{e}]}$ The advantages and drawbacks of these proteins are very similar to those described above for nanobodies. Indeed, the advantages of artificial proteins are their small size, high stability, high yield of production, use as building block of multivalent/multifunctional constructs, ability to work intracellularly. Moreover, due to their high stability, artificial proteins can support the introduction of non-natural amino acids in order to further increase their resistance to proteolysis or for their functionalization. ${ }^{[109]}$ The essential drawback is the immunogenicity; this later can be evaluated and reduced in silico using for example Lonza's proprietary Epibase in silico platform.

\section{Methods for Protein Modification}

The emergence of protein engineering in the last half century has led to several improvements in the design of attached groups and the approaches of conjugation. Covalent ligations can be performed on different accessible amino acid residues located on the surface of proteins, allowing a stable conjugation of several kinds of therapeutic payloads. In this section the different chemical and enzymatic reactions used either for a random or, site-specific conjugation of proteins are described. Bioconjugation strategies presented below are not limited to applications for extending therapeutic protein half-life.

\subsection{Chemical Reactions}

\subsubsection{NHS Ester Ligation}

Random coupling to aliphatic lysine residues (via carbamate, urethane or amide linkage) has been the gold standard for protein conjugation since decades thanks to its ease and high yield in organic synthesis (Table 8). ${ }^{[110]}$ Lysines are highly prevalent in proteins (i.e., they represent from $6 \%$ to $10 \%$ of the sequence) and they stand as one of the most reactive amino acid toward several reagents. ${ }^{[111]}$ Activated carboxylic acid esters, such as $\mathrm{N}$-hydroxysuccinimide (NHS), placed at one of the termini of the entity to attach, react in basic medium (pH: 7.9-8.5) with $\varepsilon$-amine groups of lysine to form a peptide bond (Table 8 , Scheme 1).

While the NHS ester is predominantly used to perform conjugation on lysines, it can also react with the imidazole group of histidines or the hydroxyl group of tyrosines depending on the $\mathrm{pH}$ and the temperature of the reaction. If fixed ratios of NHS to proteins lead to a quite reproducible grafting in the average number of conjugated moieties, their distribution is widely dispersed with heterogenous mixtures of unconjugated protein and protein conjugated with one or more moieties. By contrast, imidazole-1-sulfonyl azide can convert histidine amines to azides at $\mathrm{pH} 8.5$ which can then react with an alkyne group bearing payload (Staudinger reaction or strain-promoted azidealkyne cycloaddition), resulting in a more limited number of conjugates. ${ }^{[112]}$ Random conjugation can potentially alter protein activity or antigen-binding affinity in the case of immunoglobulins if conjugation is made on CDR regions.

Despite product heterogeneity, the NHS ligation has been successfully applied in a wide range of therapeutic applications and particularly for the preparation of PEGylated conjugates of foreign proteins with reduced immunogenicity (cf. Section 2.1.2).

To circumvent the drawback of heterogeneity, numerous further strategies have been investigated to perform site-directed conjugation on sites not involved in the protein function with controlled stoichiometry and minimal structural consequences. One attractive site to perform selective conjugation is the $\alpha$-amino group of the $\mathrm{N}$-terminal amino acid. ${ }^{[113]}$ The $\mathrm{N}$-terminal amine is basic and charged at physiological $\mathrm{pH}$. It is solvent-exposed in about $80 \%$ of the cases as demonstrated by in silico studies performed on 425 monomeric proteins. ${ }^{[114]}$ The $\mathrm{N}$-terminal $\alpha$-amine has a basic $\mathrm{pK}_{\mathrm{a}}(\approx 7.8)$ lower than that of lysine amino groups $\left(\mathrm{pK}_{\mathrm{a}} \approx 10.5\right)$, due to the inductive effect of the carbonyl group situated nearby. At acidic $\mathrm{pH}$, the proportion of $\mathrm{NH}_{2}$ to $\mathrm{NH}_{3}{ }^{+}$for both the alpha-amino and Epsilon-amino groups is low although higher for the alpha-amino than for the Epsilon-amino groups. Nucleophilic attack of the alpha-amino group on NHS esters (acylation) or aldehydes (alkylation) is then favored at acidic $\mathrm{pH}$. However, the $\mathrm{pH}$ of the reaction should not be too low to avoid degradation of the protein and a too low reactivity of the alpha-amino group. ${ }^{[115]}$ Chemoselective targeting of the $\mathrm{N}$-terminal $\alpha$-amine represents an asset to obtain reproducible well-defined protein monoconjugates with more uniform PK/PD properties. One of the best examples of the efficiency of such conjugation is the approval of Pegfilgrastim (Neulasta), a human granulocyte colony-stimulating 
Table 8. Overview of the main chemical reactions used for protein bioconjugation.

\begin{tabular}{|c|c|c|c|c|c|}
\hline $\begin{array}{l}\text { Scheme } \\
\text { entry }\end{array}$ & $\begin{array}{l}\text { Chemical } \\
\text { conjugation }\end{array}$ & Sites of modification & Advantages & Drawbacks & Site-specific \\
\hline \multirow[t]{2}{*}{1} & NHS Ester & Lysine & Simple and reliable & Heterogenous labeling & No \\
\hline & & $\mathrm{N}$-terminus (acid $\mathrm{pH}$ ) & & Risk of decreasing protein functionality & Yes \\
\hline \multirow[t]{3}{*}{$2 a$} & Maleimide & Reduced cysteine & Simple & Heterogeneous labeling & No \\
\hline & & Cysteine C-terminus & Can increase protein stability & Requires genetic engineering & Yes \\
\hline & & Engineered cysteine THIOmabs & Homogeneous labeling & Requires genetic engineering & Yes \\
\hline \multirow[t]{2}{*}{$2 b$} & bis-Thiol & Disulfide bridge & Homogeneous labeling & Risk of disulfide scrambling & Yes \\
\hline & maleimide & & Increase structural stability & & \\
\hline \multirow[t]{3}{*}{$2 c$} & Aryl palladium & Cysteine & Homogeneous labeling & Toxicity of palladium & Yes \\
\hline & complexes & & Preserves functionality & & \\
\hline & & & Stable toward oxidation & & \\
\hline \multirow[t]{2}{*}{$2 d$} & Aldehyde & Cysteine $\mathrm{N}$-terminus & Stable & Requires first-step genetic engineering & Yes \\
\hline & & $\mathrm{N}$-terminus (acid pH) & monolabeling & Risk of decreasing protein functionality & Yes \\
\hline \multirow[t]{3}{*}{3} & Hydrazine & Oligosaccharides & $\mathrm{pH}$-dependent cleavage & Heterogenous labeling & No \\
\hline & & & & Limited to glycoproteins & \\
\hline & & & & Risk of undesired cleavage & \\
\hline \multirow[t]{3}{*}{4} & NTA & Histidine tag $\mathrm{N}$ - or $\mathrm{C}$-terminus & Monolabeling & Toxicity of nickel & Yes \\
\hline & & & & Requires genetic engineering to add & \\
\hline & & & & HisTag on the protein & \\
\hline \multirow[t]{2}{*}{5} & IEDDA & Lysines, cysteines or post-NNAA & Covalent, quick, highly & 2-steps approach & $\mathrm{No}^{\mathrm{a})} / \mathrm{Yes}$ \\
\hline & & & specific, nontoxic & Risks of TCO isomerization & \\
\hline \multirow[t]{2}{*}{-} & NNAA & $\mathrm{N}$ - or C-terminus & Homogeneous labeling & Difficult engineering process & Yes \\
\hline & incorporation & & & Risk of immunogenicity & \\
\hline
\end{tabular}

IEDDA: Inverse-electron-demand Diels-Alder cycloaddition; NNAA: non-natural amino acid; NTA: Ni-nitrilotriacetic acid; TCO: trans-cyclooctene; ${ }^{a}$ If random labeling on lysines.

factor conjugated to a linear $20 \mathrm{kDa}-\mathrm{PEG}$ via reductive alkylation at slightly acidic $\mathrm{pH}(4.5-4.8$; Table 1$) .{ }^{[16]}$

\subsubsection{Reactions on Cysteine Residues}

To circumvent the randomness of lysine conjugation, other approaches have been developed for coupling on cysteine, tyrosine, arginine, or histidine residues either via chemical reduction of amino acid side chain functions or addition of reactive amino acids by genetic engineering. ${ }^{[17]}$ The most predominant reactions, summarized in Table 8 , involved maleimides, diazonium salts, or metallocarbenoid reagents. ${ }^{[118]}$ Maleimide coupling occurs between the high nucleophilic cysteine residue and thiol-reactive groups (Scheme 2a). A thioether bond is formed through the hetero Michael addition, attaching covalently the thiol group to the payload. Maleimide reaction above $\mathrm{pH} 8$ should be avoided because reaction with amino groups may take place.

However, cysteine is one of the three less abundant amino acids in proteins, along with tryptophan and methionine, with a preponderance of about $1.7 \%$ of free cysteines on the protein surface. ${ }^{[119]}$ Most of protein cysteines are involved in disulfide bridges or are catalytic residues. ${ }^{[120]}$ This limitation implies the need for a first genetic engineering step to add a solvent accessible free-cysteine, generally located at the C-terminus of the protein which can easily react with maleimides. This approach has gained high interest since the past decade due to the increasing need for homogenous conjugates for biomedical applications. Single cysteines at the C-terminus easily oxidize to form protein dimers or glutathione adducts, which should first be reduced by reducing reagents-such as tris(2-carboxyethyl)phosphine or 2-mercaptoethylamine-to obtain reactive sites. ${ }^{[120,121]}$ After reduction of the disulfide bridge, free cysteines can be alkylated with payloads functionalized with maleimide function. This alkylation allows the covalent attachment of the payload to the protein. ${ }^{[122]}$ For instance Certolizumab Pegol (Cimzia) is produced by conjugation of a single cysteine added at the hinge region of the anti-TNF $\alpha$ Fab antibody fragment to a 2-armed $40 \mathrm{kDa}$ PEG.

Thioether bonds are however prone to thiol-exchange reactions and can undergo a retro-Michael exchange process, particularly toward serum albumin or glutathione at physiological $\mathrm{pH} \cdot{ }^{[123]}$ Hydrolysis of the thioether bond may influence PK or<smiles>[R2]CCCCN</smiles><smiles>[R2]CCCCNC([R])=O</smiles>

Scheme 1. Reaction between $\mathrm{N}$-hydroxysuccinimide (NHS) ester bearing moiety and the aliphatic $\mathrm{NH}_{2}$ function of a protein lysine residue. 
a<smiles>[R]CSC1CC(=O)N([R2])C1=O</smiles>

b<smiles>[R]SS[R]</smiles><smiles>[R3]N1C(=O)C(Br)=C(Br)C1=O</smiles><smiles>[CH]1CC1</smiles><smiles>[R][R]SC1=C(S[R])C(=O)N([R3])C1=O</smiles>

C

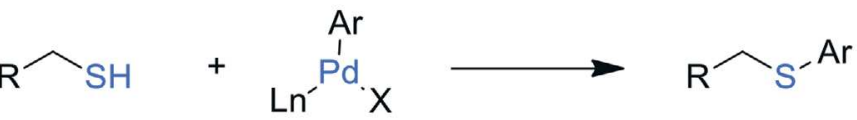

d<smiles>[R]NC(=O)C(N)CS</smiles><smiles>[R2]CN1CSCC1C(=O)N[R1]</smiles>

Scheme 2. Main reactions for the bioconjugation of moieties on cysteine residues. a) Reaction between maleimide and a free cysteine. b) Bis-thiol maleimide reaction on protein-bearing reduced cysteine. c) Aryl-palladium complex reaction on free cysteine. d) Aldehyde reaction on $\mathrm{N}$-terminus free cysteine.

have consequences on PD and the nondesired cleavage of the payload from the protein can induce off-target toxicity. Alternative maleimide constructs and reactions to cysteine residues have therefore been investigated to generate physiologically stable conjugates via the formation of irreversible thioether linkage. Next-generation maleimides have been developed, with functionalization of some leaving groups in position 3 or 4 of the maleimide to obtain covalent linkages and preserve the maleimide scaffold for a second thiol addition. ${ }^{[123 b, 124]}$ This strategy consists first in reducing the intramolecular disulfide bridge to obtain two free reactive cysteines and then, reforming an intermolecular bridge with a bifunctional payload such as dibromomaleimide (Scheme 2b). ${ }^{[125]}$ Rebridging with a dibromopyridazinedione construct itself carrying two orthogonal reactive handles could be utilized to introduce two distinct functionalities on the disulfide bridge. ${ }^{[126]}$ This conjugation method provides a homogeneous labeling as well as the precise control of stoichiometry associated with a higher stability of conjugated proteins thereby leading in enhanced PK/PD properties. ${ }^{[123 a]}$ Furthermore, dibromomaleimide and dibromopyridazinedione cross-linking reagents are both highly stable toward hydrolysis and highly reactive with cysteine residues. ${ }^{[127]}$ Comprehensive reviews about the chemical mechanisms underlying the conjugation with maleimides are available here. ${ }^{[123]}$

Recent approaches to avoid retro-Michael addition have been published. One of them consists in performing a transcyclization reaction between a maleimide moiety and an N-terminal cysteine to obtain a 6-member ring locking the thioether moiety. The trapping of the thioether can be an elegant tool for synthesizing more stable maleimide protein conjugates. ${ }^{[128]}$ Other teams suggested to perform self-hydrolyzing of the maleimide, right after conjugation, to make them lose their reactivity toward thiols. ${ }^{[129]}$ An interesting work also suggested that maleimide thiol adducts can be stabilized easily through stretching by mechanical force via mild ultrasonication. ${ }^{[130]}$ However, those promising up-to-date maleimide strategies are still at the stage of proof-of-concept and have not been applied in products in clinical trials yet.

The environment surrounding the conjugation site is involved in thiol-exchange or hydrolysis of maleimide payloads. Junutula and co-workers demonstrated the negative influence of the conjugation site on solvent accessibility, charge, propensity to maleimide exchange and downstream impacts on PK and pharmacology. ${ }^{[131]}$ By comparing an antibody conjugated to monomethyl auristatin E (MMAE) at different sites in the heavy and light chains of the Fab or Fc regions the authors observed disparities in the therapeutic activities. The conjugation of MMAE on the light or heavy chain of the Fab region was the most appropriate sites for inhibiting tumor growth and improving survival in mice. The observed differences were correlated with the respective pharmacokinetic properties of the conjugates, the Fab-light chain conjugates showing the highest stability in blood. Mass analysis suggested that both the maleimide exchange from the antibody conjugate and the hydrolysis of succinimide ring in the linker influenced conjugate stability and therapeutic activity. To avoid such deleterious effects, the same team developed the THIOmabs technology by engineering two cysteines in the constant domains of Fab fragment of antibodies, one in each arm, thus generating two known sites of bioconjugation for stable thioether linkages. ${ }^{[132]}$ These sites have been carefully selected using a phage display-based method to avoid alteration of domains involved in antigen binding functions. Such genetic engineering strategy 


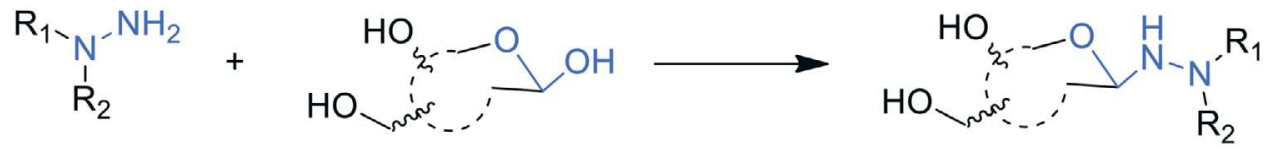

Scheme 3. Bioconjugation on oligosaccharides using a hydrazine-bearing moiety.

revolutionized protein bioconjugation with its ability to induce minimal changes in the antibody structure and functionality.

Some alternatives to maleimide reaction for selective conjugation to cysteine residues have also been investigated, among them, the use of metal complexes, such as palladium (Scheme 2c). ${ }^{[133]}$ Briefly, a biarylphosphine bearing palladium reagent is used to transfer an aryl group onto a cysteine residue then form a covalent thioether bond. Proof of concept of aryl palladium (II) conjugation has been demonstrated on different proteins such as antibodies, protein A, and sortase A. ${ }^{[13,134]}$ The thiol arylation with such metal complexes is interesting as it results in highly stable bioconjugates toward oxidation and acid degradation. However, applications in biological systems remain difficult due to the toxicity of palladium.

A cysteine residue positioned at the $\mathrm{N}$-terminus of a protein can be selectively conjugated due to its distinct 1,2-aminothiol functionality. ${ }^{[135]}$ Thereby, aldehydes-bearing payloads can react with the N-terminal cysteine to form thiazolidines without interfering with other nucleophilic residues such as serines, lysines or other internal cysteines (Scheme 2d). However, the reaction occurs in acidic conditions (i.e., $\mathrm{pH} 4-5$ ), exhibits slow kinetics (up to 2 days) and requires high concentrations of reactants. ${ }^{[136]}$ A recent study demonstrated that the reaction induces quick dissociation of about $10 \%$ to $25 \%$ of the payload depending on the $\mathrm{pH}$. These observations suggest that this approach could be more appropriate for prodrugs or antibodydrug conjugates-for which the detachment of the payload in endosomes could be an asset for therapeutic efficacy-than for the conjugation of long-acting nanomedicines. ${ }^{[137]}$

\subsubsection{Glycosylation of Proteins}

Glycosylation is generally achieved via post-translational modification through an enzymatic process allowing the conjugation of glycans to the chains on asparagine (i.e., $\mathrm{N}$-glycosylation), serine or threonine (i.e., O-glycosylation) (Scheme 3).[138] Protein glycosylation is strongly dependent on the expression system used as the expression system induces variations in the nature and number of glycans added, which can affect the biodistribution of the protein.

Selective conjugation of glycans on N-glycoproteins is performed using hydrazine reactive moieties, based on the oxidation of hydroxyl to aldehyde groups in oligosaccharides using sodium periodate. A covalent bond is thus formed between the aldehyde and the hydrazine group allowing the conjugation of a wide variety of functionalized materials. ${ }^{[139]}$ However, the hydrazide reaction of oxidized glycans as well as the purification methods to remove the unconjugated moieties highly influence the efficiency, stability, and functionality of the N-glycoprotein conjugates. ${ }^{[140]}$ Such bioconjugation strategy remains mainly used for in vitro protein immobilization, purification or in vivo identification and quantification in diagnostic applications more than for developing nanomedicines. ${ }^{[141]}$

\subsubsection{N- or C-Term Conjugation via Ni-Nitrilotriacetic Acid (NTA)}

Nickel (II) chelate complex of nitrilotriacetic acid $\left(\mathrm{Ni}^{2+}\right.$-NTA) was originally developed for the immobilization of His-tagged proteins on a surface, as required for BIACORE analysis systems. ${ }^{[142]}$ However, due to the complementary interaction between the His-Tag and Ni(II)-NTA this approach is also attractive for site-specific bioconjugation at the His-tag of recombinant proteins (Scheme 4). ${ }^{[143]}$ Complexation of NTA-bearing moiety with protein $\mathrm{N}$ - or C-term His tag exhibits an affinity of about $10^{-6} \mathrm{M}$. The reaction is fast and selective and generally allows to preserve protein activities.

NTA demonstrated interesting results with the possibility to either conjugate fluorescent probes to proteins or to directly target specific His-Tag proteins in cells (with cognate cell ligandbearing protein) thereby offering great opportunities for specific protein tracking in living systems with minimal alterations on the protein structure, function, or localization. ${ }^{[144]}$ Other metals such as cobalt (II) or (III) have also been used with the NTA system to target the protein His-Tag and demonstrate high
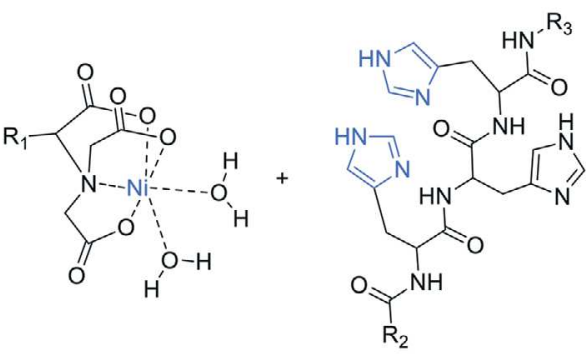

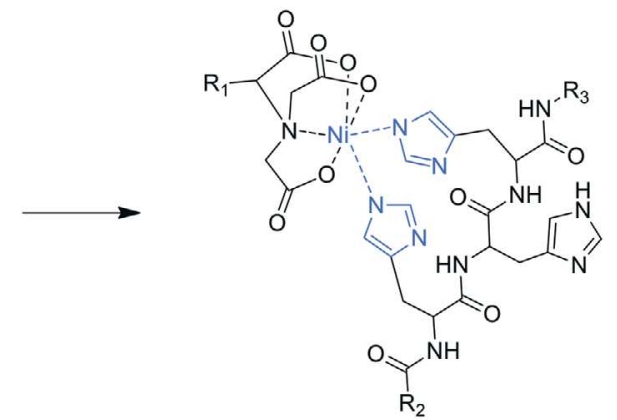

Scheme 4. Bioconjugation at N- or C-term of histidine residues using Ni-nitrilotriacetic acid (NTA). 
stability as well as inertia toward ligand exchange. ${ }^{[145]}$ However, to date, NTA was mainly applied to nanoparticles engineering and did not succeed in in vivo experiments yet, an issue resulting from its versatility, reversibility, and metal toxicity.

\subsubsection{Bioorthogonal Click Chemistry}

Bioorthogonal click chemistry encompasses different highly specific and rapid chemical reactions that occur in living systems, at physiological $\mathrm{pH}$ and temperature, without the need of a catalyzer and where the chemical moieties used are totally inert toward biological molecules which ensures biocompatibility. ${ }^{[146]}$ A decade ago, bioorthogonal click chemistry started to be investigated for in vivo protein labeling especially using polymers, toxins, radionuclides or cytotoxic molecules. ${ }^{[147]}$ Bioorthogonal chemistry conjugation is performed in a twosteps approach where the protein is first conjugated to a highly reactive chemical and then the counterpart chemical bearing the moiety to attach is added in a separate step. One of the most popular bioorthogonal reactions is the inverse-electron demand [4 + 2] Diels-Alder cycloaddition (IEDDA), which occurs between a poor electronic diene, such as 1,2,4,5-tetrazine (Tz) and a dienophile alkene such as trans-cyclooctene (TCO) to form a covalent bond (Scheme 5). ${ }^{[146,147]}$

TCO (or Tz, as the invert reaction is also feasible) is conjugated to proteins through different ways. ${ }^{[148]}$ The most common method remains the random conjugation on lysine residues. However, site-specific conjugation, via engineered cysteine residues, C-term residues or other amino acids incorporated by genetic engineering (cf. Section 4.1.6), has been used in the last few years to control reaction stoichiometry and avoid modifications on the functional part of the protein. Thanks to a high reaction kinetic rate (i.e., $k_{2}$ up to $10^{6} \mathrm{M}^{-1} \mathrm{~s}^{-1}$ ), IEDDA allows conjugating proteins to theranostic payloads either before in vivo administration (direct protein modification) or by delaying administrations of protein and payloads by a few minutes to several days (indirect protein modification) for a binding occurring directly in vivo. ${ }^{[148]}$ The latter is especially appropriate for pretargeting in a 2-steps strategy developed to reduce off-target toxicity induced by long-acting antibody carrying cytotoxic payloads. ${ }^{[146,147]}$ However, the IEDDA reaction is also an interesting tool to conjugate PEG or SA to protein for the development of long-acting medicines.

The major drawback of this reaction arises from the isomerization of TCO into its inactive isomer cis-cyclooctene, which occurs over time after protein-TCO has been administered in blood due to nonspecific interactions with transition metals. ${ }^{[149]}$ Indeed, cis-cyclooctene is the most favorable conformation as the cis position of the $\mathrm{C}=\mathrm{C}$ in the cycle is more stable. TCO is thus synthesized from cis-cyclooctene by photochemical conversion and has to undergo quality check before any coupling as it is prone to isomerize. ${ }^{[150]}$ The risk of isomerization has to be particularly considered for pretargeting strategies and implies limiting the delay between the injection of the protein-TCO and the payload-bearing Tz. However, in the case of direct coupling before in vivo administration of the complex, the risk of isomerization remains negligible, TCO being highly stable in PBS during several weeks. ${ }^{[149 b]}$

Click chemistry progressively becomes a very useful tool in biochemistry, especially for protein bioconjugation due to its ease of use. Another bioorthogonal reaction, the SPAAC has recently demonstrated efficacy for site specific PEGylation of fibroblast growth factor 2 with a slightly improved half-life in mice. ${ }^{[151]}$ Today, about a dozen of bioorthogonal click reactions have been developed for in vitro or in vivo applications. The choice of the appropriate reaction is highly dependent on the reaction rate, the type of protein targeted, the moiety to attach and the desired application. ${ }^{[152]}$ While those reactions are specific, catalyst free and nonimmunogenic, their application in living systems are recent and still challenging. The TCO/Tz IEDDA cycloaddition was the first bioorthogonal reaction to enter clinical trials last October 2020 for application in oncology as an antibody-drug conjugate (NCT04106492).

\subsubsection{Non-Natural Amino-Acid Incorporation}

Genetic engineering can be used to insert non-natural amino acids (NNAAs) in proteins to allow site-specific chemical conjugation at known sites without involving natural amino acids from the original protein sequence. ${ }^{[153]}$ NNAAs are incorporated genetically by reprogramming a rarely used codon or a nonsense codon in the gene of interest achieved by an orthogonal pair aminoacyl tRNA synthetase (aaRS) that loads a specific tRNA with an NNAA. The selected NNAA-specific synthetase must not recognize any host tRNAs or cognate amino acids while the orthogonal tRNA anticodon must not be aminoacylated by any host aaRS and should be mutated to recognize a stop codon or a nonsense codon (Figure 3). ${ }^{[154]}$ The amber stop codon TAG is frequently used for NNAA incorporation as this codon is rarely used in E. coli and is one of the lowest used in humans (i.e., occurrence of TAG in humans: $23 \%) .{ }^{[155]}$ Today, over 80 NNAAs have been encoded into proteins in
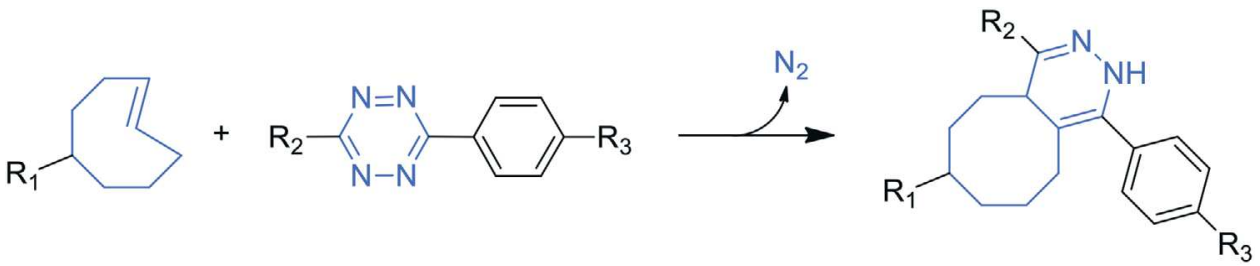

Scheme 5. Inverse-electron demand Diels-Alder (IEDDA) cycloaddition between trans-cyclooctene (TCO) and 1,2,4,5-tetrazine (Tz). The covalent bioorthogonal reaction is associated with a release of $\mathrm{N}_{2}$. Note: inverse reaction with R1-linked Tz followed by the addition of R2-TCO works also but is less described. 


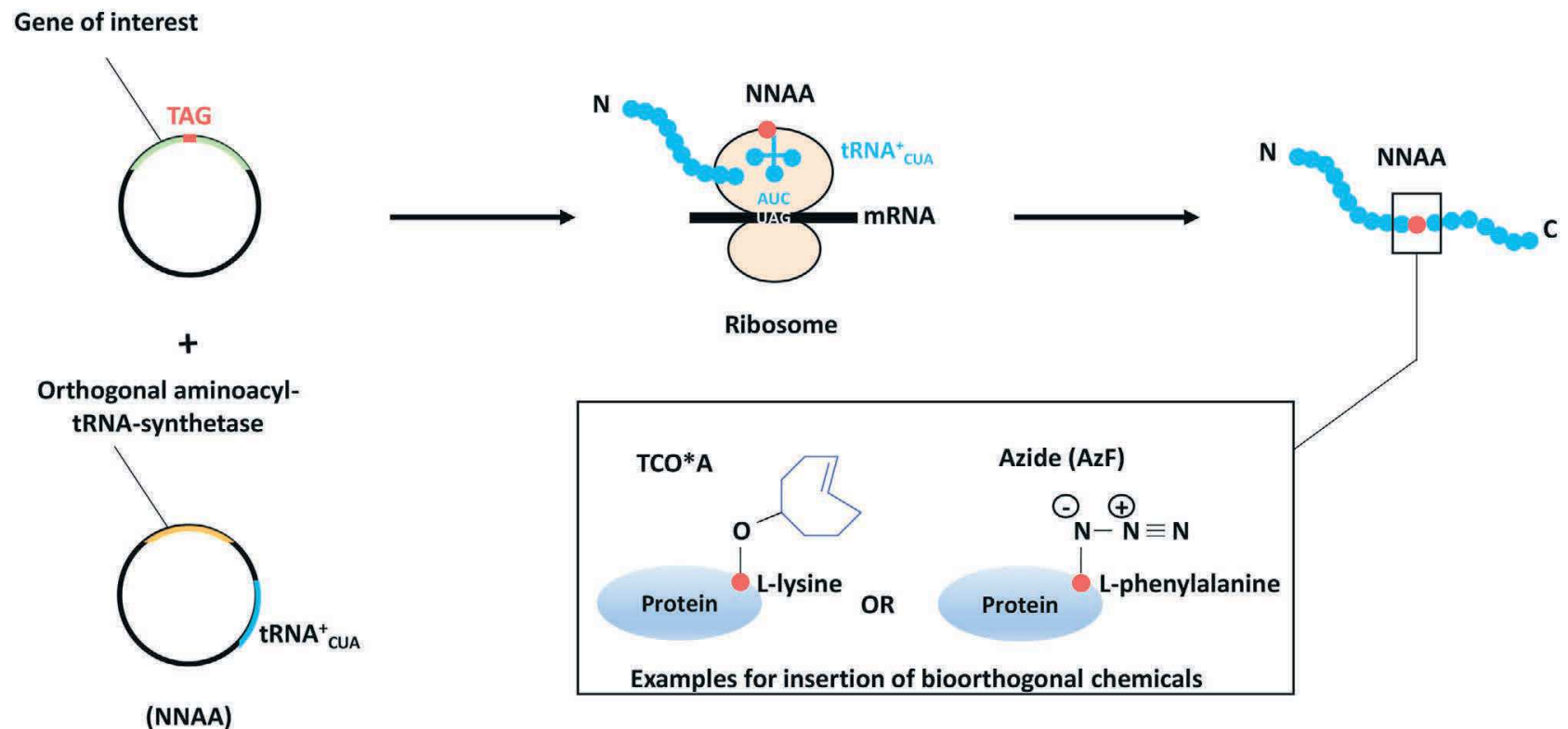

Figure 3. Incorporation of non-natural amino acids (NNAA) bearing bioorthogonal moiety into a protein via the Amber stop codon (TAG) approach. Examples with the incorporation of trans-cyclooctene-L-lysine (TCO*A) and p-azido-L-phenylalanine (AzF).

several prokaryotic and mammalian in vivo expression systems leading to proteins functionalized either with PEGs, chemicals or radionuclides. ${ }^{[156,157]}$

Recently, cell free synthesis has been developed as a rapid, cost-effective, and virus-free process for manufacturing protein bearing NNAA. Employing a Methanocaldococcus jannaschii TyrRS-derived synthetase/tRNA pairs, Otting and co-workers succeeded to incorporate a variety of NNAA, such as para-acetyl-L-phenylalanine, bipyridyl-phenylalanine or L-(7-hydroxycoumarin-4-yl) ethylglycine in E. coli-based cell-free expression system but failed to incorporate para-azido-L-phenylalanine required for further click chemistry reaction. ${ }^{[158]}$ Later, another team succeeded to incorporate para-azidomethylL-phenylalanine for performing strain-promoted azide-alkyne cycloaddition. ${ }^{[153 a]}$ Thereby, NNAA has been effective in human cells for the incorporation of amino acid bearing bioorthogonal components such as azide moiety (for Staudinger or strainpromoted azide-alkyne cycloaddition) or cyclooctene moiety (for IEDDA cycloaddition) into eGFP expression plasmid (Figure 3). ${ }^{[159]}$ P-azido-L-phenylalanine was incorporated in eGFP via the orthogonal $M$. jannaschii TyrRS-derived synthetase/tRNA pairs and the E. coli aaRS encoded on two separate plasmids while TCO-L-lysine incorporation was mediated by an orthogonal tRNA/aaRS pair from Methanosarcina mazei coencoded on a single plasmid.

Since the last decade, NNAA incorporation has gained increasing interest as it enables the attachment of various organic probes to proteins without inducing deleterious modifications of the functional region of proteins. Compared to classical chemical reactions on solvent free amino acid residues, the NNAA approach is advantageous as it allows selective conjugation of moieties while preserving the moiety linkage from the risk of unspecific cleavage. However, the need of genetic engineering on proteins is a constraint, in terms of cost, materials and time of accomplishment, which can be a major drawback in comparison to easy and quick chemical conjugation on lysines or cysteines. To date, there is no protein-conjugated NNAA in the market yet as this approach is in its early stage preclinical development.

\subsection{Chemoenzymatic Reactions}

Chemoenzymatic reactions are an excellent way to selectively conjugate payloads to proteins; the main approaches are summarized in Table 9. Enzymes can be used either to tag the protein or as a catalyzer for chemical conjugation. Chemoenzymatic reactions can be used on WT or genetically engineered proteins, thereby combining different conjugation approaches to obtain optimal conjugates with tightly controlled stoichiometry. ${ }^{[160]}$ The choice of the method is critical to obtain proteins conjugated with optimal PK/PD and stability. A wide variety of molecules can be conjugated to proteins, each with specific purposes, ranging from polymers to antibodies, enzymes, toxins, drugs, cytokines or other proteins. ${ }^{[160,161]}$ It is also interesting to note that combinations of different moieties can be performed to multiply different desired effects.

\subsubsection{Biotinylation}

Biotinylation is one of the easiest ways to modify proteins with enzymes (Table 9). Biotin (also known as vitamin $\mathrm{H}$, vitamin B7 or coenzyme R) is a small cofactor of 244 Da for carboxylase enzymes present in all living organisms. Avidin is a positively charged tetrameric protein of about $60 \mathrm{kDa}$ naturally found in white eggs of birds, reptiles and amphibians; its bacterial analog, streptavidin, being produced by Streptomyces avidinii. ${ }^{[162]}$ 
Table 9. Overview of the main chemoenzymatic reactions used for protein conjugation.

\begin{tabular}{|c|c|c|c|c|}
\hline Chemoenzymatic conjugation & Sites of modification & Advantages & Drawbacks & Site-specific \\
\hline Biotin & Lysine & Simple & Heterogeneous labeling, (Strept)avidin toxicity & Yes/No \\
\hline Sortase & LPXTG glycine tag & Homogeneous labeling & $\begin{array}{c}\text { Engineering of LPXTG motif } \\
\text { Recreates original sequence motif } \\
\text { Need high molar excess }\end{array}$ & Yes \\
\hline OaAEP1 & Glycine-valine & $\begin{array}{l}\text { Homogenous labeling } \\
\text { Does not recreate the } \\
\text { original sequence motif }\end{array}$ & Engineering the modified motif & Yes \\
\hline Transglutaminase & Glutamine & Highly homogeneous labeling & May require a first-step of genetic engineering & Yes \\
\hline GalT/SialT & Asparagine & Homogeneous labeling & $\begin{array}{c}\text { Multisteps engineering } \\
\text { Oxidation of methionine residues }\end{array}$ & Yes \\
\hline GalT/GalNAz & Asparagine & High homogeneous labeling & Multisteps engineering & Yes \\
\hline GlycoConnect & Serine or threonine & Homogeneous labeling & Multisteps engineering & Yes \\
\hline Formylglycine generating enzyme & Cysteine & Homogeneous labeling & Engineering of CXPXR sequence & Yes \\
\hline
\end{tabular}

GalT: $\beta$-1,4-galactosyltransferase; GalNAz: galactosyltransferase N-azidoacetyl-galactosamine; LPXTG: lysine-proline-X (any amino acid)-tyrosine-glycine tag; SialT: $\alpha$-2,6-sialytransferase.

The interaction between biotin and (strept)avidin is one of the strongest known noncovalent biological reaction with a $K_{\mathrm{D}}$ of about $10^{-15} \mathrm{M}$ at $\mathrm{pH}$ 5.0. The ligation is also quick, highly specific, and highly stable, allowing the reaction to resist the action of protease or denaturant agents and occurs even under harsh conditions such as high temperature or $\mathrm{pH}$, an asset for stable attachment of polymers, proteins, fluorophores or other payloads. ${ }^{[162]}$

Chemical conjugation of biotin, often performed on lysine residues generates heterogenous products. However, biotin ligase can also be used as a catalyzer for the enzymatic conjugation of biotin derivatives onto proteins thereby leading to homogeneous products. ${ }^{[160,163]}$ This technology is ATP-dependent and requires a biotin ligase, such as BirA which is produced in E. coli, and a previous step of genetic engineering on the protein to add a polypeptide sequence (e.g., AviTag peptide as specific substrate of BirA enzyme) specific for the enzyme. ${ }^{[164]}$ Indeed, Schatz and co-workers have found a sequence of 13 amino acids to be the minimal substrate for BirA enzyme (i.e., LXYIFEAQKIEWR, where $\mathrm{X}=$ any amino acid and $\mathrm{Y}=$ any except $\mathrm{L}, \mathrm{V}, \mathrm{I}, \mathrm{W}, \mathrm{F}$ or $\mathrm{Y})$. In order to improve the rate of biotinylation, the sequence has then been improved several times resulting in AviTag (GLNDIFEAQKIEWHE), BioTag (ALNDIFEAQKIEWHA), and other derivatives. Briefly, the Tag peptide is genetically inserted either at the $\mathrm{N}$ - or C-terminus or even in exposed loops of the target protein. The coaddition of BirA, biotin, and ATP in the reaction medium forms an intermediate biotinoyl-5'-AMP stuck in BirA ligase until the enzyme recognizes the Tag sequence. Metabolization of the Tag substrate by BirA release the biotinoyl-5'-AMP intermediate which reacts with the proximal lysine residue contained in the sequence of the Tag fusion protein for covalent bioconjugation (Figure 4).

Site-specific functionalization of proteins using biotin ligase has been demonstrated for numerous applications, as for example for the in vivo quantification of protein-protein proximity of Sox 2 and Oct4 transcription factors, the labeling of cell surface proteins or to conjugate polymers, other proteins or chemical payloads. ${ }^{[165]}$ However, if such strategy brings an interesting prospective, (strept)avidin immunogenicity still impedes further clinical development. ${ }^{[166]}$

\subsubsection{Transpeptidation}

A number of transpeptidases, including sortase A from Staphylococcus aureus (the most extensively used), butelase- 1 from the tropical plant Clitoria ternatea and OaAEP1 from the cyclotideproducing plant Oldenlandia affinis have been used to modify proteins site specifically (Table 9). These enzymes cleave the peptide bond of a specific motif (cleavage motif highlighted in green in Figure 5) and form a new peptide bond with an incoming nucleophile composed of specific amino acids (the receiving motif highlighted in red in Figure 5) to which a payload of choice is attached. The payload is often another peptide or protein but importantly, nongenetically encoded functional groups can be fused to proteins according to this approach given that they are synthesized and chemically grafted to the appropriate cleavage or incoming motif (Figure 5). Such nongenetically encoded functional groups include PEG, dyes, biotin, oligonucleotides, radioisotope, unnatural amino acid, lipids, or carbohydrates. ${ }^{[167]}$ Since the reaction is carried out in organic solvent-free mild conditions, most proteins can be modified according to this approach without affecting their structure and stability. The unique requirement is that they can first be equipped, at the appropriate location, with a cleavage sequence and/or an incoming sequence by genetic engineering and produced recombinantly. The specific design features required depend on which terminus of the protein the modification is desired and on which enzyme or combination of enzymes is used. A short, flexible linker often composed of Gly ${ }_{4}$ Ser repeats is usually added between the target protein and the engineered cleavage site. ${ }^{[168]}$

Sortase: Sortase, as the other transpeptidases, can be used to modify proteins at their C-ter and/or N-ter. ${ }^{[169]}$ In order to modify a protein at its C-terminus, a specific LPXTGG cleavage motif is added by genetic engineering to the C-terminus of a 


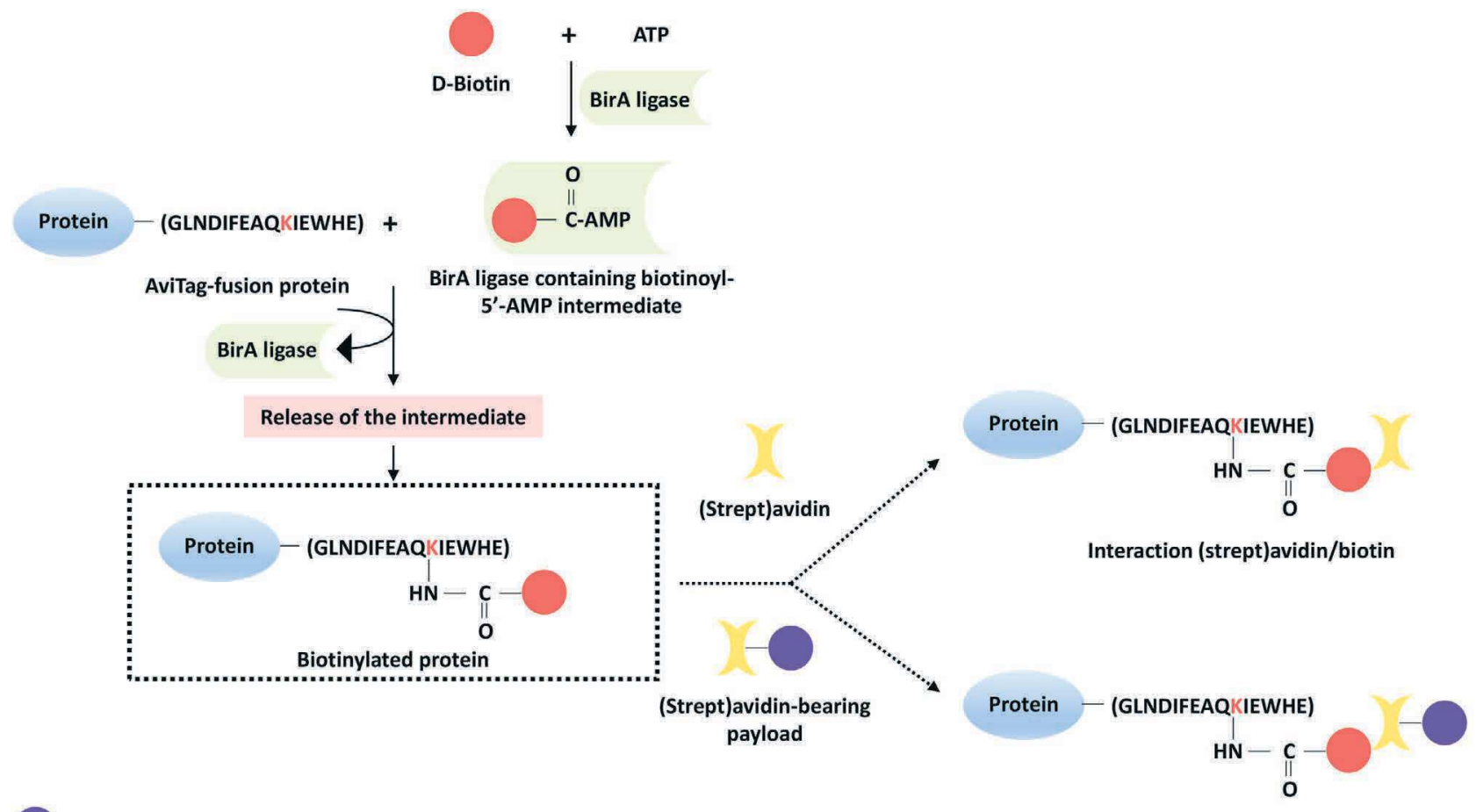

Payload (PEG, protein, toxin, drug, etc.)

Complex [protein-biotin/(strept)avidin-payload]

Figure 4. Site-specific enzymatic biotinylation using BirA ligase. BirA recognizes specifically biotin and the 15-amino acids AviTag sequence genetically inserted in the $\mathrm{N}$ - or C-terminus of the target protein. The ATP-dependent reaction results in the formation of biotinoyl-5'-AMP intermediate stuck into BirA until the ligase recognizes the lysine of the AviTag peptide. The acylation of the lysine forms a covalent bond between the AviTag-fused protein and biotin. Biotin can then react with wild-type (strept)avidin for in vitro protein detection or be conjugated with (strept)avidin-bearing payload for direct in vivo administration or for indirect pretargeting strategies.

protein of interest, while an incoming nucleophile $\mathrm{G}(\mathrm{n})$ motif is added-by genetic engineering or chemical synthesis-to the N-terminus of the payload to be ligated. If the protein has to be modified at its $\mathrm{N}$-terminus, then the receiving nucleophile motif should be genetically engineered at this position, while the cleavage motif is added to the payload. An illustration of these two scenarios is given for sortase A-mediated modification in Figure 5A. With a specific design of the target protein, sortase has also been used to prepare unnatural C-to-C fusions of two different proteins or to label the protein at the internal position of its sequence. ${ }^{[167 a, 168]}$ The completion of the sortase reaction recreates the sequence motif originally recognized by the enzyme, so that the reaction is reversible. In the absence of an adequate concentration of incoming nucleophile motif, the acylenzyme intermediate is remarkably stable, and the reaction is driven to completion only in the presence of a significant molar excess of the incoming nucleophile. ${ }^{[167 a]}$ The reconstitution of the cleavage motif in the ligation product prevents, therefore, the use of WT-sortase A to successively label a protein at both its $\mathrm{N}$ - and C-termini. One of the first applications of sortase to protein engineering was the conjugation of cytokines with PEG to extend the cytokine half-life via direct coupling with a GG-PEG payload. ${ }^{[170]}$ Sortase is also capable of protein cyclization to improve the stability of a protein. To achieve this the nucleophile GG is added to the N-terminus of the protein, while the LPTXGG motif is attached to the C-terminus. ${ }^{[170]}$ To circumvent the poor kinetic parameters of WT sortase, mutational variants of sortase A, with at least threefold improved catalytic efficiency compared to the WT enzyme, have been produced leading to a better coupling yields. ${ }^{[171]}$ Moreover, recent studies with a series of sortase mutational variants showed that different variants can lead to substantially better results according to the protein modification that is desired. Thus, there is not such a thing like a unique sortase able to perform all kinds of reactions efficiently, but a set of variants each one dedicated for a specific application. A comprehensive comparison of different variants is available in the work carried out by Li et al. ${ }^{[172]}$ Moreover, new transpeptidases, with specific characteristics, have been recently identified such as VyPAL2. ${ }^{[173]}$ In addition, from the 3D-structure of different transpeptidases and their mutational variants, the molecular bases underlying efficient ligase activity start to be understood and could be used for the rational engineering of enzymes with the desired catalytic activity. ${ }^{[173]}$ Moreover, optimization of transpeptidation protocols involving for example the use of immobilized enzymes allows to reduce significantly the amount of enzyme needed and it should allow to scale-up reactions for an industrial use. ${ }^{[174]}$

Recently, the sortase reaction has been a matter of extensive research in the field of imaging and radiology. One example is the labeling of nanobodies with ${ }^{111}$ In for singlephoton emission computed tomography. ${ }^{[175]}$ In this approach, a nanobody is tagged with the motif LPTXG at its C-terminal and the peptide GGGKY is functionalized with the chelating 


\section{A. Sortase}
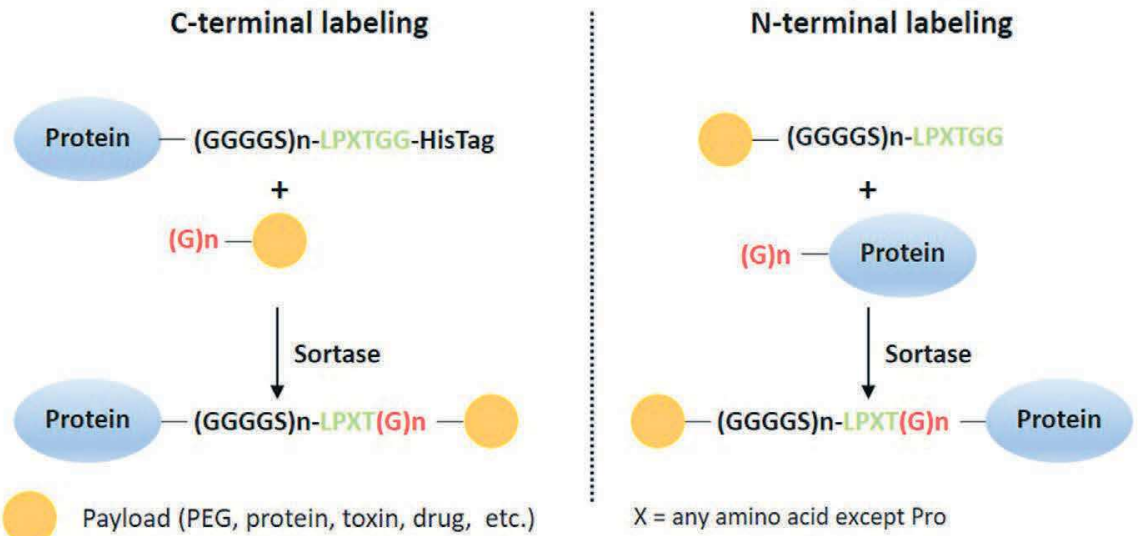

Payload (PEG, protein, toxin, drug, etc.)

$\mathrm{X}=$ any amino acid except Pro
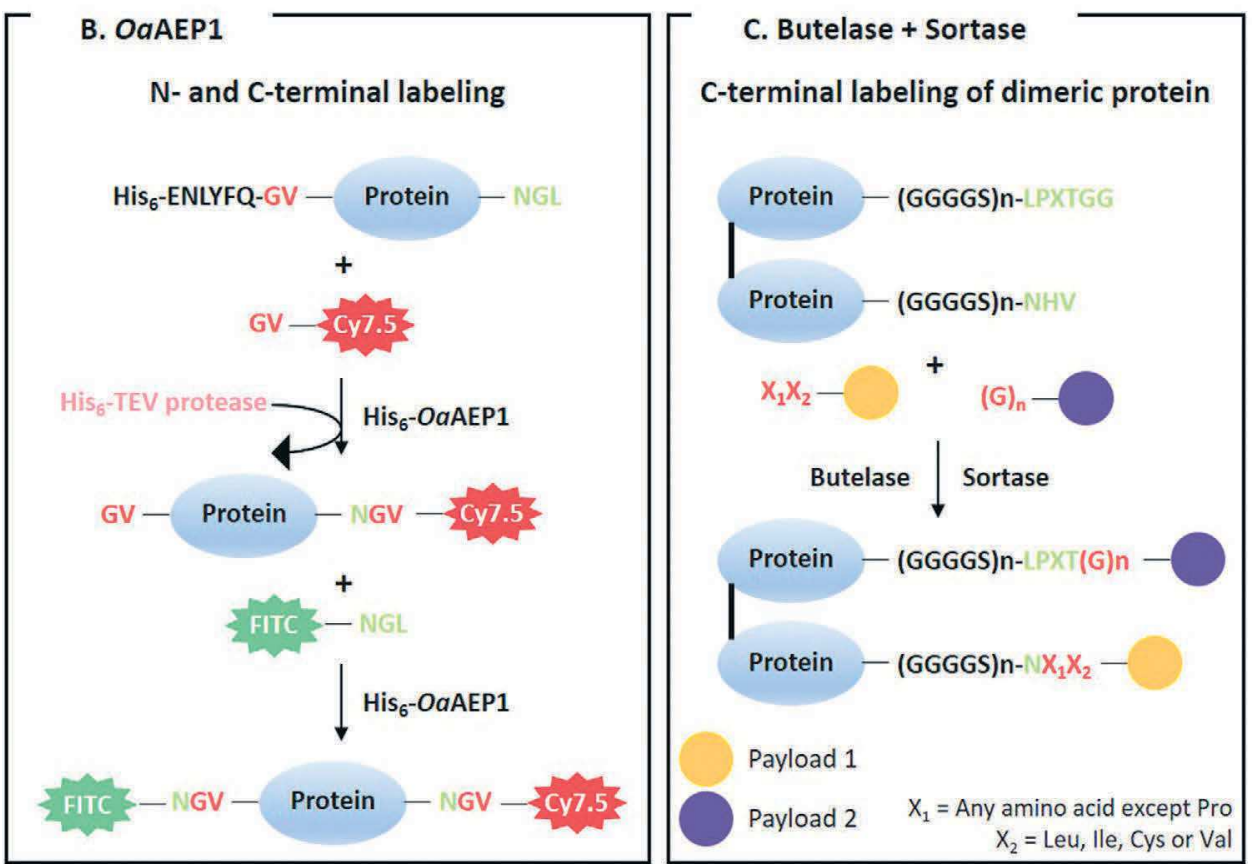

Figure 5. Site-specific modification of proteins using transpeptidases. A-C) The cleavage motif and the incoming nucleophile motif are shown in green and red, respectively. (GGGGS)n constitutes the linker. (A) Sortase A-mediated modification of a protein at its C- or N-terminus: Sortase A specifically recognizes the LPXTG (X = any amino acid) motif. It mediates the bioconjugation by cleaving the bond between threonine ( $T$ ) and glycine ( $\mathrm{G}$ ) for binding the desired moiety, fused via an oligoglycine. (B) Sequential double labeling of a protein with two fluorescence probes via OaAEP1. (C) Simultaneous labeling of a dimeric protein (with an intermolecular disulfide bond) using butelase 1 and sortase A.

agents CHX-A"-DTPA and NOTA to bind to the radioactive isotope. The sortase catalyzes the site-specific incorporation of the chelating agent at the C-terminal of the nanobody yielding a stoichiometric and homogenous product that can be easily separated by size-exclusion chromatography. Among the numerous applications of labeling antibodies in radiology, the image-guided surgery is one of the most innovative and has a high potential to become a standard practice in oncologic surgery in the future. ${ }^{[176]}$ It however requires a precise and rapid delimitation of the tumor to be excised in the course of a surgery with exquisite contrast to normal tissues. Given their versatility, specificity, and the short time needed to attain high contrast, nanobodies are very promising in this field. ${ }^{[177]}$
Butelase: The cysteine-transpeptidase butelases show a substantially higher catalytic efficiency than sortases and a shorter cleavage motif (D/N-HV), leaving an $\mathrm{N}$ residue after cleavage (Figure 5C). The recent peptide specificity characterization of a recombinant butelase produced in E. coli, using a EGFR binding affibody model has allowed the synthesis of cyclic affibody doxorubicine conjugates with conserved affinity toward EGFR-overexpressing A431 cells. ${ }^{[178]}$ Given the superior catalytic efficiency of this enzyme, and the possibility of E. coli expression, we expect substantial progress in protein engineering strategies based on butelases in the coming future.

OaAEP1: In the case of OaAEP1, by screening different nucleophile motives, Rehm et al. identified a GV dipeptide 
that readily served as a nucleophile in the ligation reaction, but the product of that reaction (NGV) is poorly recognized by the enzyme. ${ }^{[167 b]}$ Thus, the ligation product is resistant to the reverse reaction and this allows a straightforward efficient sitespecific sequential modification of a protein of interest both at the $\mathrm{C}$ and $\mathrm{N}$ terminus using the same enzyme (Figure 5B). Such an approach was efficiently used to prepare a nanobody functionalized with two fluorescent probes: Cy7,5 at the C-Ter and fluorescein at the N-ter. ${ }^{[167 b]}$ The nanobody was first equipped with i) a TEV protease recognition sequence (ENLYFQ) at the N-terminus, followed by the GV sequence. ${ }^{[167 b]}$ The TEV sequence initially protects the GV sequence from the attack of the enzyme, and ii) a C-terminal NGL. In a first reaction, the C-terminus of the nanobody was fused with a Cy7.5labeled GV nucleophile, generating the NGV sequence at the C-terminus. Then, TEV was added to the reaction mixture to remove the ENLYFQ sequence and thus expose the GV nucleophile at the N-terminus. Finally, the N-terminus was fused with a fluorescein-labeled NGL probe, while leaving the C-terminal NGV sequence generated in the first ligation intact. The labeling at each step was higher than $90 \%$ as determined by mass spectrometry and the product could be purified easily using an IMAC chromatography (i.e., the His-tagged transpeptidase and TEV bind to the column) and a cut-off filtration to remove enzymes and probe between steps. A similar strategy was used to create polymerized proteins step by step in a rationally controlled sequence. ${ }^{[179]}$ WT OaAEP1 has low kinetic parameters that limit its utilization in bioconjugation of proteins, nevertheless the mutation C247A substantially increases the catalytic efficiency of the enzyme. ${ }^{180]}$

Dual Site-Specific Coupling Using a Combination of Transpeptidases: Interestingly, since each transpeptidase possesses a specific cleavage and receiving motives, it is possible to use a combination of two of them to label a protein at two distinct sites in a one-pot reaction and thus creating multimodal proteins (Figure 5C). For example, sortase A and butelase 1 were used to label an IgG at both the C-terminus of its light and heavy chain. ${ }^{[168]}$ The IgG was first modified genetically to add a sortase LPETGG cleavage motif at the C-terminus of the light chain and a butelase NHV cleavage motif at the C-terminus of the heavy chain. Two different fluorescent probes bearing an appropriate incoming nucleophile motif were synthesized: i) an oligo-glycine peptide bearing 5,6-carboxyfluorescein (GGG-FAM) and ii) an alanine-leucine peptide bearing the AlexaFluor 647 fluorescent (AL-Alexa). The modified IgG was incubated with GGG-FAM, AL-Alexa, sortase A, and butelase 1 at $4{ }^{\circ} \mathrm{C}$ for $15 \mathrm{~h}$ followed by incubation at $37^{\circ} \mathrm{C}$ for $4 \mathrm{~h}$. The yield of labeling for each fluorescent probe was higher than $95 \%$. A simple centrifugationbased size exclusion was used to remove unincorporated dyes and enzymes, and to obtain pure dually modified IgG. Another dual labeling involving two transpeptidases (i.e., butelase and VyPAL2) in one single pot allowed to modify an EGFR-targeting affibody with a fluorescein tag and a mitochondrion-lytic peptide at its respective $\mathrm{N}$ - and C-terminal ends. ${ }^{[178]}$ Moreover, butelase was used in conjunction with a $\pi$-clamp conjugation to conjugate the C-terminus of an scFv-Fc of the 4B3monoclonal antibody (i.e., an $\mathrm{mAb}$ specific for the human EphA2 receptor which is overexpressed in glioblastoma) simultaneously to a rhodamine and a fluorinated biphenyl-PEG11-fluorescein. ${ }^{[181]}$

\subsection{3. $\mathrm{N}$ - and O-Glycan Engineering}

$\mathrm{N}$ - and O-glycan engineering is a recent tool for embedding chemical reporters within glycans via the $N$-glycan terminus of asparagine residues using multisteps chemoenzymatic reactions (Table 9). At first, this approach was developed to label glycans directly in cells with chemical reporters for diagnostic detection. Using endogenous biosynthetic cell-surface pathways, chemical reporters have been embedded in glycans via the metabolic introduction of sialic acid, $\mathrm{N}$-acetylgalactosamine or $\mathrm{N}$-acetylglucosamine monosaccharides bearing azides (Figure 6A). ${ }^{[159]}$ Selective glycoconjugation has proven to be effective for PEGylation of FVIII (Esperoct) and rFIX protein (Refixia) commercialized for the treatment of hemophilia A and B, respectively. ${ }^{[182]}$ CMP-activated sialic acid-6'-40 kDa PEG was first transferred using sialyltransferase to terminal galactoses of O-linked glycan of N8 peptide (FVIII protein) or $\mathrm{N}$-glycans of N9 peptide (rFIX protein) and then sialylated by addition of excess unmodified CMP-sialic acid. The reaction achieved a product yield of about $99 \%$ and glycoPEGylation preserved the biological activity of the protein. ${ }^{[183]}$

Recent advances in post-translational remodeling of native glycan located at specific asparagine residues (e.g., Asn-297)via the combination of $\beta$-1,4-galactosyltransferase (GalT) and $\alpha$-2,6-sialyltransferase (SialT) —within the Fc domain of mAbs allow to incorporate sialic acid moieties. ${ }^{[184]}$ The latter is then mildly oxidized to introduce functional aldehyde groups which can subsequently be conjugated with aldehyde-reactive aminooxy bearing payload (Figure 6B). ${ }^{[185]}$ However, the oxidation of sialic acid for the conversion into aldehyde also induces the oxidation of methionine residues, an issue requiring new optimizations. Thereby, a recent chemoenzymatic bioconjugation strategy, called GlycoConnect, uses endoglycosidase $\mathrm{S}$ to hydrolyze the chitobiose core of Asn-297-linked heavy chain Fc glycans (Figure 6C). Then, $\beta$-1,4-galactosyltransferase T (Y289L) and $\mathrm{N}$-azidoacetylgalactosamine are both added to the reaction medium of the immunoconjugate to incorporate azides into the residual glycan chains. ${ }^{[186]}$ The azido residue finally allows to perform click chemistry to conjugate several kinds of conjugates, ranging from biological (peptides, proteins, toxins, oligonucleotide) to chemicals (cytotoxic drug, radionuclide, fluorescent probe, nanoparticle). To improve the therapeutic effect, dendronized chemical structures can be clicked to the azide moiety thereby providing several binding moieties with minimal modifications on the antibody. This recent strategy was efficient to conjugate 8 reactive TCO (4 on each part of the $\mathrm{IgG}_{1} \mathrm{Fc}$ ) with only two sites of modification for pretargeting purposes. The dendrimeric scaffold demonstrated specific interaction and showed a significantly higher uptake in tumors than the nondendronized one. ${ }^{[186 b]}$

\subsubsection{Formylglycine Generating Enzyme}

In aerobic conditions, the formylglycine generating enzyme oxidizes cysteine and serine side chains into formylglycine (Table 9). ${ }^{[187]}$ Physiologically, formylglycine-generating enzyme activates type-I sulfatases by post-translational generation of the catalytic $\mathrm{C}^{\alpha}$-formylglycine leading to the 
A

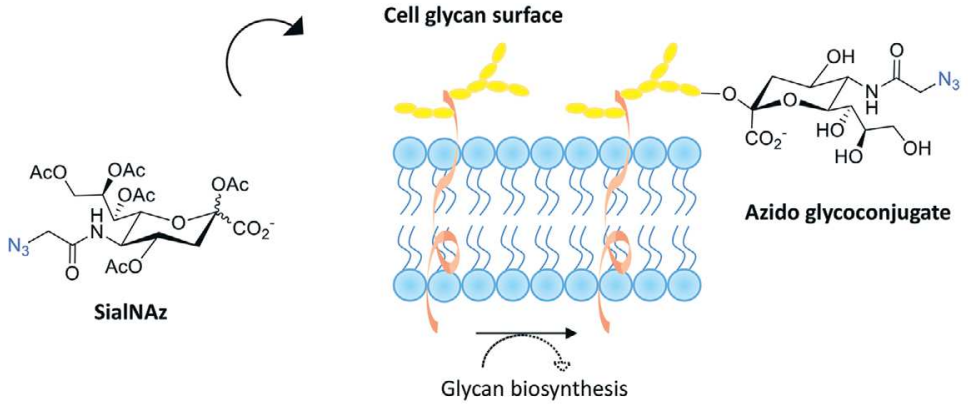

B

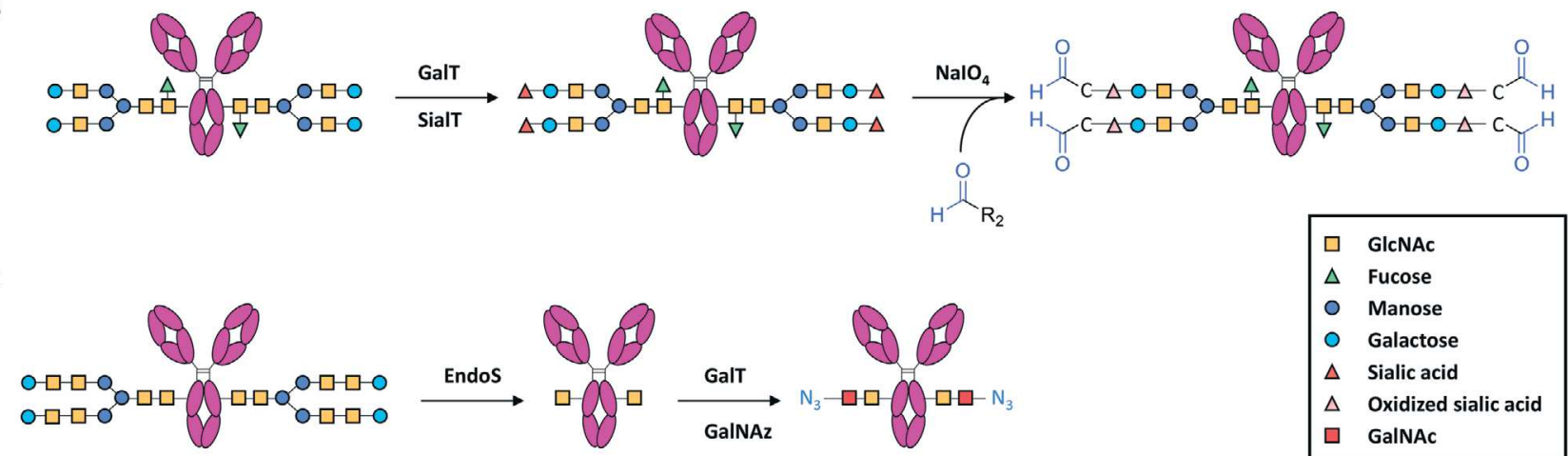

Figure 6. Different strategies for $\mathrm{N}$-glycan engineering. A) Direct conjugation of azide-chemical reporter on cell surface glycans via endogenous biosynthetic pathways. B) General antibody $N$-glycan engineering using the combination of $\beta$-1,4-galactosyltransferase (GalT) and $\alpha$-2,6-sialyltransferase (SialT). NalO4 is then added to oxidize sialic acid into reactive aldehyde. C) Simplified GlycoConnect strategy developed by Zeglis and co-workers. Endonuclease S first hydrolyzes Asn-297 then $\beta$-1,4-galactosyltransferase T (Y289L) and N-azidoacetylgalactosamine are both added to introduce an azide moiety for further click chemistry reaction. GalNAc: N-acetylgalactosamine; GlcNAc: N-acetylglucosamine.

conversion of a cysteine $(\mathrm{C})$ or serine $(\mathrm{S})$ residue embedded in a highly conserved $\mathrm{C}$ (or S) XPXR minimal motif (X = any amino acid, into an aldehyde-bearing formylglycine, with a conversion rate of $75 \%$ to $90 \%$. Formylglycine-generating enzyme is an interesting strategy for site-specific bioconjugation as this system not only recognizes the required motif in sulfatases but also in recombinant proteins engineered with the minimal motif CXPXR, called "aldehyde tag," allowing the introduction of bioorthogonal reactive chemicals in the protein of interest (Figure 7). Indeed, aldehydes are a highly reactive electrophile suitable for bioorthogonal reactions such as aminooxy or hydrazide reagents to form oxime and hydrazine conjugates, respectively, as previously described in Sections 4.1 .2 and 4.1.5. ${ }^{[188]}$

The formylglycine generating enzyme method is quite simple, only requiring to encode the CXPXR motif at the desired site of the gene of interest in an appropriate expression vector to be inserted at the $\mathrm{N}$ - or $\mathrm{C}$-terminus of the protein or within internal regions to facilitate a protein design without critical alterations of protein stability or functionality. ${ }^{[189]}$

Thereby, the formylglycine generating enzyme is efficient for site-specific PEGylation of proteins or for the conjugation of fluorogenic probes and payloads. However, its main application deals with oncology for the construction of antibodydrug conjugates. ${ }^{[188,190]}$ To improve the conversion rate, recent attempts have been made with copper(II)-containing media as a catalyst of the reaction. Despite improving the in vitro activity 20 -fold, the toxicity of copper makes application in living systems challenging. ${ }^{[191]}$

\section{Conclusions and Perspectives}

The high specificity of their biological activities renders proteins particularly attractive drugs for the treatment of a wide range of diseases. Yet, many proteins are rapidly cleared from the systemic circulation and need to be injected several times a week or even a day to patients. This high therapy burden jeopardizes patient quality of life, patient adherence and therapeutic outcomes of medications. Therefore, a major medical need for biologics with a prolonged half-life has arisen and protein engineering and chemistry have been able to answer this demand.

The discovery that conjugation to PEG was able to decrease protein immunogenicity and to prolong blood circulating half-life has been the first significant milestone in the field. PEGylation resulted in the marketing of several biobetters with prolonged half-life comprising a few PEGylated conjugates of prokaryote and animal proteins. These latter are particularly remarkable because they are able to relieve severe human diseases such as leukemia and severe combined immunodeficiency disease. Yet, the non-biodegradability of PEG represents a limitation of this polymer and scientists have turned to natively disordered polypeptides such as XTEN, PAS, and ELP as PEG alternatives. In addition to biodegradability, polypeptide polymers are genetically fused to the parent biologic and can be expressed in E. coli. Although no polypeptide fusion proteins have reached the market yet, several are in clinical development.

In parallel to conjugation to polymers, scientists have exploited the FcRn-mediated recycling pathway to design 


\section{$\mathrm{N}$ - and C-terminal labeling}

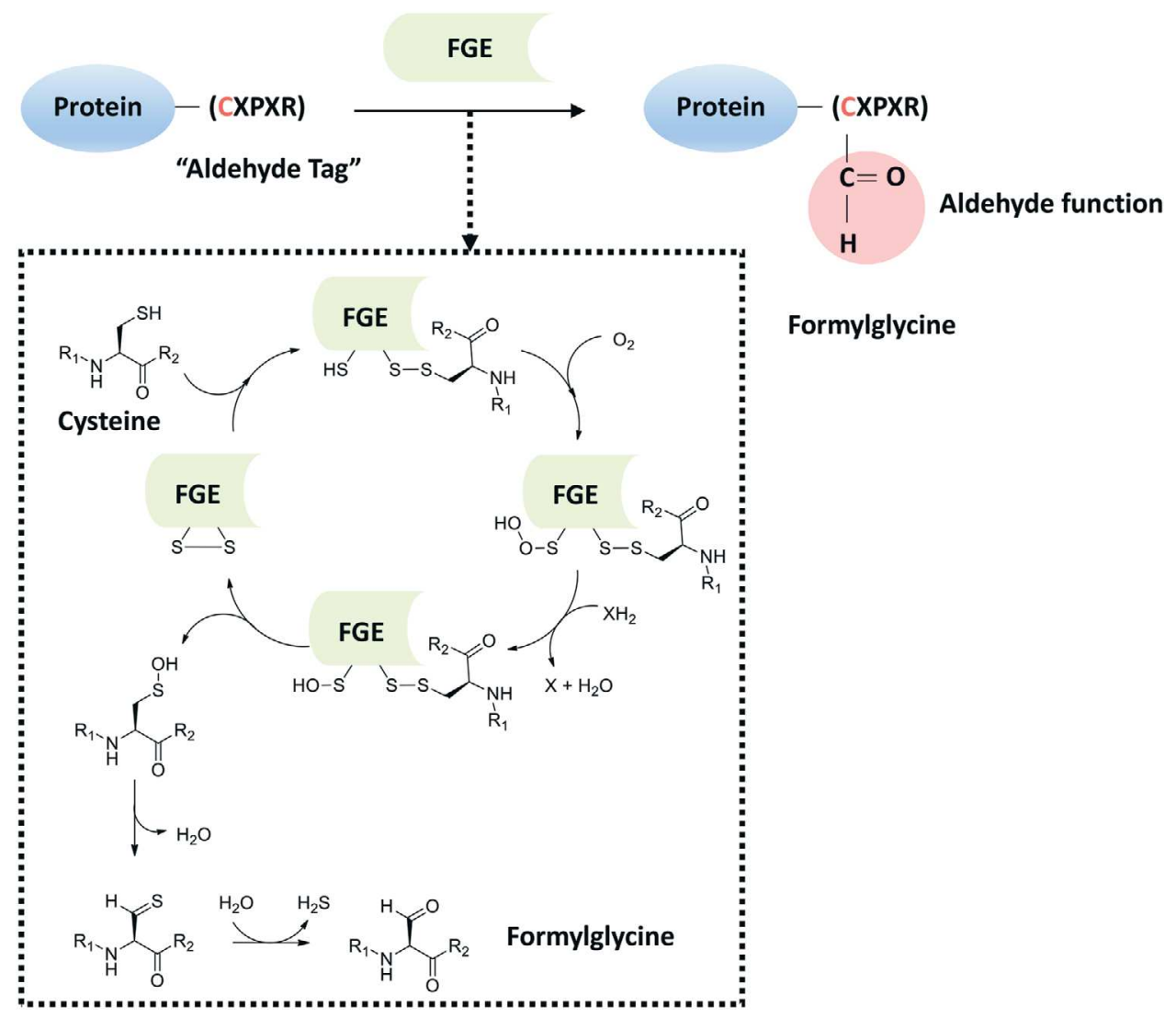

Figure 7. Conversion of cysteine embedded in CXPXR motif into formylglycine-bearing reactive aldehyde using formylglycine-generating enzyme (FGE). The CXPXR (C: cysteine, P: proline, R: arginine, and X: any amino acid) motif called "aldehyde tag" is first genetically encoded in the target protein. FGE catalyzes the conversion of the cysteine into formylglycine-bearing reactive aldehyde through the proposed catalytic mechanism (aerobic condition). The newly formed aldehyde then allows bioorthogonal reactions with various hydroxylamines or hydrazines-bearing payloads.

proteins with prolonged half-life. Therefore, IgG and albumin have been harnessed to prolong the half-life of proteins by either fusing the therapeutic protein to an FcRn binding region or by conjugating the therapeutic protein to a molecule that noncovalently binds to albumin. Etanercept, the first biobetter based on FcRn recycling, has been marketed in 1998. It is a fusion protein between the TNF- $\alpha$ receptor and the Fc of an IgG1 antibody. Most of the Fc- and albumin-fusion proteins have been produced by genetic engineering. The second approach where the therapeutic protein is fused to molecules binding endogenous SA has also resulted in several marketed biobetters and insulin Detemir, a myristic acid-insulin conjugate, is certainly the most known. However, research and development are still on-going in this area and molecules binding albumin are sought in bacterial proteins as well as antibody fragments.

Several biobetters have been easily produced by genetic fusion. However, others have required more complex chemical or chemoenzymatic reactions. Initial reactions have used the abundance of lysine residues in proteins to randomly ligate polymers. Although random conjugation causes a significant loss in protein activity, it is also the most effective to cover antigenic sites and to decrease the immunogenicity of nonhuman proteins. Therefore, the interest in random conjugation is expected to persist in the coming years. Yet, the chemistries mostly investigated lately have involved site-specific ligation in order to avoid grafting peptides or prosthetic groups too close to the active site and losing protein activity. In this regard, chemoenzymatic reactions are an excellent way to selectively conjugate payloads to proteins. Selective glycoconjugation has proven to be effective for PEGylation of coagulation factors with the recent marketing of Nonacog beta pegol and Turoctocog alfa pegol in 2017 and 2019, respectively.

In this review, we emphasized the intense activity and the constant development of the protein engineering field to provide biobetters with optimized PK profiles to patients. Yet, challenges and opportunities remain. Up to now, only PEGylation has been investigated as an approach to decrease protein immunogenicity. Because PEG is non-biodegradable, substitute biodegradable polymers should be identified with this goal. The abundance of IgGs and albumin in blood and their long serum half-life have made them ideal target carriers for engineering therapeutic protein constructs with extended circulation time. The future is likely to witness the use of immunoglobulinbinding domains, as alternatives to albumin-binding domains, to prolong the half-life of proteins. 


\section{Acknowledgements}

This work was supported by research grants of the Fonds National de la Recherche Scientifique (FNRS, Belgium; Grant No. T023819F) and Belgian Walloon Region (WALInnov Grant No. 1710173). Mireille Dumoulin and Rita Vanbever are Research Associate and Research Director of the FNRS, respectively.

\section{Conflict of Interest}

The authors declare no conflict of interest.

\section{Keywords}

chemical conjugation, chemoenzymatic reactions, Fc fusion, genetic engineering, human serum albumin, pharmacokinetics, polyethylene glycol, polypeptides, protein modifications

Received: February 16, 2021 Revised: May 19, 2021

Published online:

[1] G. Walsh, Nat. Biotechnol. 2018, 36, 1136

[2] B. Leader, Q. J. Baca, D. E. Golan, Nat. Rev. Drug Discovery 2008, 7, 21

[3] J. E. Matthews, M. W. Stewart, E. H. De Boever, R. L. Dobbins, R. J. Hodge, S. E. Walker, M. C. Holland, M. A. Bush, G. Albiglutide Study, J. Clin. Endocrinol. Metab. 2008, 93, 4810.

[4] I. Ekladious, Y. L. Colson, M. W. Grinstaff, Nat. Rev. Drug Discovery 2019, 18, 273

[5] A. Abuchowski, J. R. McCoy, N. C. Palczuk, T. van Es, F. F. Davis, J. Biol. Chem. 1977, 252, 3582.

[6] J. M. Harris, Poly(Ethylene Glycol) Chemistry (Ed: J. Milton), Springer, Boston, USA 1992.

[7] F. M. Veronese, PEGylated Protein Drugs: Basic Science and Clinical Applications, Springer, Boston, USA 2009.

[8] A. Vaisman-Mentesh, M. Gutierrez-Gonzalez, B. J. DeKosky, Y. Wine, Front. Immunol. 2020, 11, 1951.

[9] G. Lew, Clin. Cancer Res. 2020, 26, 325.

[10] M. L. Graham, Adv. Drug Delivery Rev. 2003, 55, 1293.

[11] A. L. Angiolillo, R. J. Schore, M. Devidas, M. J. Borowitz, A. J. Carroll, J. M. Gastier-Foster, N. A. Heerema, T. Keilani, A. R. Lane, M. L. Loh, G. H. Reaman, P. C. Adamson, B. Wood C. Wood, H. W. Zheng, E. A. Raetz, N. J. Winick, W. L. Carroll, S. P. Hunger, J. Clin. Oncol. 2014, 32, 3874.

[12] S. Chaffee, A. Mary, E. R. Stiehm, D. Girault, A. Fischer, M. S. Hershfield, J. Clin. Invest. 1992, 89, 1643.

[13] L. Wu, J. Chen, Y. Wu, B. Zhang, X. Cai, Z. Zhang, Y. Wang, L. Si, H. Xu, Y. Zheng, C. Zhang, C. Liang, J. Li, L. Zhang, Q. Zhang, D. Zhou, J. Controlled Release 2017, 249, 84.

[14] R. Adams, L. Griffin, J. E. Compson, M. Jairaj, T. Baker, T. Ceska, S. West, O. Zaccheo, E. Dave, A. D. Lawson, D. P. Humphreys, S. Heywood, $m A$ Abs 2016, 8, 1336.

[15] A. P. Chapman, Adv. Drug Delivery Rev. 2002, 54, 531.

[16] M. J. Guichard, T. Leal, R. Vanbever, Curr. Opin. Colloid Interface Sci. 2017, 37, 43 .

[17] A. M. Cantin, D. E. Woods, D. Cloutier, E. K. Dufour, R. Leduc, Am. J. Respir. Cell Mol. Biol. 2002, 27, 659

[18] D. Freches, H. P. Patil, M. Machado Franco, C. Uyttenhove, S. Heywood, R. Vanbever, Int. J. Pharm. 2017, 521, 120.

[19] S. I. Koussoroplis, G. Paulissen, D. Tyteca, H. Goldansaz, J. Todoroff, C. Barilly, C. Uyttenhove, J. Van Snick, D. Cataldo, R. Vanbever, J. Controlled Release 2014, 187, 91.
[20] M.-J. Guichard, T. Wilms, S. Mahri, H. P. Patil, D. Hoton, B. Ucakar, K. Vanvarenberg, P. Cheou, M. Beka, E. Marbaix, T. Leal, R. Vanbever, Adv. Ther. 2020, 4, 2000146.

[21] S. Mahri, A. Rondon, T. Wilms, C. Bosquillon, R. Vanbever, J. Controlled Release 2020, 10, 1054.

[22] S. Mahri, E. Hardy, T. Wilms, H. De Keersmaecker, K. Braeckmans, S. De Smedt, C. Bosquillon, R. Vanbever, Int. J. Pharm. 2021, 593, 120107.

[23] Y. Yamamoto, Y. Tsutsumi, Y. Yoshioka, T. Nishibata, K. Kobayashi, T. Okamoto, Y. Mukai, T. Shimizu, S. Nakagawa, S. Nagata, T. Mayumi, Nat. Biotechnol. 2003, 21, 546.

[24] F. M. Veronese, G. Pasut, Drug Discovery Today 2005, 10, 1451.

[25] K. Sprogoe, E. Mortensen, D. B. Karpf, J. A. Leff, Endocr. Connect. 2017, 6, R171

[26] a) L. Holten-Andersen, S. Pihl, C. E. Rasmussen, J. Zettler G. Maitro, J. Baron, S. Heinig, E. Hoffmann, T. Wegge, M. Krusch, F. Faltinger, S. Killian, K. Sprogoe, D. B. Karpf, V. M. Breinholt, F. Cleemann, J. Bone Miner. Res. 2019, 34, 2075; b) V. M. Breinholt, C. E. Rasmussen, P. H. Mygind, M. Kjelgaard-Hansen, F. Faltinger, A. Bernhard, J. Zettler, U. Hersel, J. Pharmacol. Exp. Ther. 2019, 370,459 .

[27] a) F. M. Veronese, A. Mero, F. Caboi, M. Sergi, C. Marongiu, G. Pasut, Bioconjugate Chem. 2007, 18, 1824; b) M. J. Guichard, H. P. Patil, S. J. Koussoroplis, R. Wattiez, T. Leal, R. Vanbever, Int. J. Pharm. 2017, 524, 159.

[28] C. Roque, A. Sheung, N. Rahman, S. F. Ausar, Mol. Pharm. 2015, $12,562$.

[29] B. Treetharnmathurot, C. Ovartlarnporn, J. Wungsintaweekul, R. Duncan, R. Wiwattanapatapee, Int. J. Pharm. 2008, 357, 252.

[30] a) P. Caliceti, F. M. Veronese, Adv. Drug Delivery Rev. 2003, 55, 1261; b) T. Yamaoka, Y. Tabata, Y. Ikada, J. Pharm. Sci. 1994, 83, 601.

[31] a) I. Hamad, A. C. Hunter, J. Szebeni, S. M. Moghimi, Mol. Immunol. 2008, 46, 225; b) M. Imran ul-haq, B. F. Lai, R. Chapanian, J. N. Kizhakkedathu, Biomaterials 2012, 33, 9135.

[32] I. A. Ivens, W. Achanzar, A. Baumann, A. Brandli-Baiocco, J. Cavagnaro, M. Dempster, B. O. Depelchin, A. R. Rovira, L. Dill-Morton, J. H. Lane, B. M. Reipert, T. Salcedo, B. Schweighardt, L. S. Tsuruda, P. L. Turecek, J. Sims, Toxicol. Pathol. 2015, 43, 959.

[33] P. Caliceti, O. Schiavon, F. M. Veronese, Bioconjugate Chem. 2001 $12,515$.

[34] a) M. Schlapschy, U. Binder, C. Borger, I. Theobald, K. Wachinger, S. Kisling, D. Haller, A. Skerra, Protein Eng., Des. Sel. 2013, 26, 489; b) M. Gebauer, A. Skerra, Bioorg. Med. Chem. 2018, 26, 2882.

[35] V. N. Podust, S. Balan, B. C. Sim, M. P. Coyle, U. Ernst, R. T. Peters, V. Schellenberger, J. Controlled Release 2016, 240, 52.

[36] a) F. Unverdorben, F. Richter, M. Hutt, O. Seifert, P. Malinge, N. Fischer, R. E. Kontermann, mAbs 2016, 8, 120; b) R. Anand, J. Vallooran, in Engineering of Biomaterials for Drug Delivery Systems (Ed: A. Parambath), Woodhead Publishing, Oxford, UK 2018, p. 299.

[37] M. Schlapschy, I. Theobald, H. Mack, M. Schottelius, H. J. Wester, A. Skerra, Protein Eng., Des. Sel. 2007, 20, 273.

[38] V. Schellenberger, C. W. Wang, N. C. Geething, B. J. Spink, A. Campbell, W. To, M. D. Scholle, Y. Yin, Y. Yao, O. Bogin, J. L. Cleland, J. Silverman, W. P. Stemmer, Nat. Biotechnol. 2009, 27, 1186.

[39] a) N. C. Geething, W. To, B. J. Spink, M. D. Scholle, C. W. Wang, Y. Yin, Y. Yao, V. Schellenberger, J. L. Cleland, W. P. Stemmer, J. Silverman, PLoS One 2010, 5, 10175; b) S. E. Alters, B. McLaughlin, B. Spink, T. Lachinyan, C. W. Wang, V. Podust, V. Schellenberger, W. P. Stemmer, PLoS One 2012, 7, 50630; c) A. Haeckel, F. Appler, L. Figge, H. Kratz, M. Lukas, R. Michel, J. Schnorr, M. Zille, B. Hamm, E. Schellenberger, J. Nucl. Med. 2014, 55, 508; d) S. Ding, M. Song, B. C. Sim, C. Gu, V. N. Podust, C. W. Wang, B. McLaughlin, T. P. Shah, R. Lax, R. Gast, 
R. Sharan, A. Vasek, M. A. Hartman, C. Deniston, P. Srinivas, V. Schellenberger, Bioconjugate Chem. 2014, 25, 1351; e) A. Haeckel, F. Appler, A. Ariza deSchellenberger, E. Schellenberger, PLoS One 2016, 11, 0157193.

[40] a) J. L. Cleland, N. C. Geething, J. A. Moore, B. C. Rogers, B. J. Spink, C. W. Wang, S. E. Alters, W. P. Stemmer, V. Schellenberger, J. Pharm. Sci. 2012, 101, 2744; b) W. V. Moore, H. J. Nguyen, G. B. Kletter, B. S. Miller, D. Rogers, D. Ng, J. A. Moore, E. Humphriss, J. L. Cleland, G. M. Bright, J. Clin. Endocrinol. Metab. 2016, 101, 1091.

[41] a) B. A. Konkle, A. D. Shapiro, D. V. Quon, J. M. Staber, R. Kulkarni, M. V. Ragni, E. S. Chhabra, S. Poloskey, K. Rice, S. Katragadda, J. Fruebis, C. C. Benson, N. Engl. J. Med. 2020, 383, 1018; b) E. Seth Chhabra, T. Liu, J. Kulman, S. Patarroyo-White, B. Yang, Q. Lu, D. Drager, N. Moore, J. Liu, A. M. Holthaus, J. M. Sommer, A. Ismail, D. Rabinovich, Z. Liu, A. van der Flier, A. Goodman, C. Furcht, M. Tie, T. Carlage, R. Mauldin, T. M. Dobrowsky, Z. Liu, O. Mercury, L. Zhu, B. Mei, V. Schellenberger, H. Jiang, G. F. Pierce, J. Salas, R. Peters, Blood 2020, 135, 1484; c) B. Nolan, J. Mahlangu, D. Perry, G. Young, R. Liesner, B. Konkle, S. Rangarajan, S. Brown, H. Hanabusa, K. J. Pasi, I. Pabinger, S. Jackson, L. M. Cristiano, X. Li, G. F. Pierce, G. Allen, Haemophilia 2016, 22, 72.

[42] A. Varanko, S. Saha, A. Chilkoti, Adv. Drug Delivery Rev. 2020, 156, 133.

[43] P. Hoffmann, R. Hofmeister, K. Brischwein, C. Brandl, S. Crommer, R. Bargou, C. Itin, N. Prang, P. A. Baeuerle, Int. J. Cancer 2005, 115, 98.

[44] U. Binder, A. Skerra, Curr. Opin. Colloid Interface Sci. 2017, 31, 10.

[45] a) D. Harari, N. Kuhn, R. Abramovich, K. Sasson, A. Zozulya, P. Smith, M. Schlapschy, R. Aharoni, M. Köster, R. Eliam, A. Skerra, G. Schreiber, J. Biol. Chem. 2014, 289, 29014; b) E. A. Zvonova, A. V. Ershov, O. A. Ershova, M. A. Sudomoina, M. B. Degterev, G. N. Poroshin, A. V. Eremeev, A. P. Karpov, A. Y. Vishnevsky, I. V. Goldenkova-Pavlova, A. V. Petrov, S. V. Ruchko, A. M. Shuster, Appl. Microbiol. Biotechnol. 2017, 101, 1975; c) F. Bolze, A. Bast, S. Mocek, V. Morath, D. Yuan, N. Rink, M. Schlapschy, A. Zimmermann, M. Heikenwalder, A. Skerra, M. Klingenspor, Diabetologia 2016, 59, 2005; d) F. Bolze, V. Morath, A. Bast, N. Rink, M. Schlapschy, S. Mocek, A. Skerra, M. Klingenspor, Endocrinology 2016, 157, 233; e) V. Morath, F. Bolze, M. Schlapschy, S. Schneider, F. Sedlmayer, K. Seyfarth, M. Klingenspor, A. Skerra, Mol. Pharm. 2015, 12, 1431; f) C. T. Mendler, A. Feuchtinger, I. Heid, M. Aichler, C. D'Alessandria, S. Pirsig, B. Blechert, H. J. Wester, R. Braren, A. Walch, A. Skerra, M. Schwaiger, J. Nucl. Med. 2016, 57, 1971; g) C. T. Mendler, L. Friedrich, I. Laitinen, M. Schlapschy, M. Schwaiger, H. J. Wester, A. Skerra, mAbs 2015, 7, 96; h) C. T. Mendler, T. Gehring, H. J. Wester, M. Schwaiger, A. Skerra, J. Nucl. Med. 2015, 56, 1112; i) M. J. Harder, N. Kuhn, H. Schrezenmeier, B. Hochsmann, I. von Zabern, C. Weinstock, T. Simmet, D. Ricklin, J. D. Lambris, A. Skerra, M. Anliker, C. Q. Schmidt, Blood 2017, 129, 970; j) N. Kuhn, C. Q. Schmidt, M. Schlapschy, A. Skerra, Bioconjugate Chem. 2016, 27, 2359; k) M. H. Hedayati, D. Norouzian, M. Aminian, S. Teimourian, R. Ahangari Cohan, S. Sardari, M. R. Khorramizadeh, Protein J. 2017, 36, 36; I) J. Breibeck, A. Skerra, Biopolymers 2018, 109; m) N. E. Powers, B. Swartzwelter, C. Marchetti, D. M. de Graaf, A. Lerchner, M. Schlapschy, R. Datar, U. Binder, C. K. Edwards, 3rd, A. Skerra, C. A. Dinarello, J. Biol. Chem. 2020, 295, 868; n) S. Mazaheri, Y. Talebkhan, F. Mahboudi, L. Nematollahi, R. A. Cohan, E. Mirabzadeh Ardakani, E. Bayat, M. Sabzalinejad, S. Sardari, F. Torkashvand, Sci. Rep. 2020, 10, 18464; o) F. Khodabakhsh, D. Norouzian, B. Vaziri, R. Ahangari Cohan, S. Sardari, F. Mahboudi, M. Behdani, K. Mansouri, A. Mehdizadeh, Artif. Cells, Nanomed., Biotechnol. 2018, 46, 1402; p) F. Khodabakhsh, M. Salimian, A. Mehdizadeh, M. S. Khosravy,
A. Vafabakhsh, E. Karami, R. A. Cohan, J. Pharmacol. Exp. Ther. 2020, 375, 69; q) E. Eggenstein, A. Richter, A. Skerra, Protein Eng., Des. Sel. 2019, 32, 289.

[46] F. C. Deuschle, V. Morath, A. Schiefner, C. Brandt, S. Ballke, S. Reder, K. Steiger, M. Schwaiger, W. Weber, A. Skerra, Theranostics 2020, 10, 2172.

[47] E. Peplau, F. De Rose, S. Reder, M. Mittelhauser, G. Scafetta, M. Schwaiger, W. A. Weber, A. Bartolazzi, A. Skerra, C. D'Alessandria, Thyroid 2020, 30, 1314.

[48] A. Richter, K. Knorr, M. Schlapschy, S. Robu, V. Morath, C. Mendler, H. Y. Yen, K. Steiger, M. Kiechle, W. Weber, A. Skerra, M. Schwaiger, Nucl. Med. Mol. Imaging 2020, 54, 114.

[49] E. Falvo, E. Tremante, A. Arcovito, M. Papi, N. Elad, A. Boffi, V. Morea, G. Conti, G. Toffoli, G. Fracasso, P. Giacomini, P. Ceci, Biomacromolecules 2016, 17, 514.

[50] G. Fracasso, E. Falvo, G. Colotti, F. Fazi, T. Ingegnere, A. Amalfitano, G. B. Doglietto, S. Alfieri, A. Boffi, V. Morea, G. Conti, E. Tremante, P. Giacomini, A. Arcovito, P. Ceci, J. Controlled Release 2016, 239, 10.

[51] E. Falvo, F. Malagrino, A. Arcovito, F. Fazi, G. Colotti, E. Tremante, P. Di Micco, A. Braca, R. Opri, A. Giuffre, G. Fracasso, P. Ceci, J. Controlled Release 2018, 275, 177.

[52] B. Tesarova, S. Dostalova, V. Smidova, Z. Goliasova, Z. Skubalova, H. Michalkova, H. David, P. Michalek, H. Polanska, M. Vacuovicova, J. Hacek, T. Eckschlager, M. Stiborova, A. S. Pires, A. R. M. Neves, A. M. Abrantes, T. Rodrigues, P. Matafome, M. F. Botelho, P. Teixeira, F. Mendes, Z. Heger, Applied Metarials Today 2020, 18, 100501.

[53] F. Brandl, H. Merten, M. Zimmermann, M. Behe, U. ZangemeisterWittke, A. Pluckthun, J. Controlled Release 2019, 307, 379.

[54] A. P. Caputi, P. Navarra, Curr. Opin. Pharmacol. 2020, 51, 93.

[55] D. M. Floss, K. Schallau, S. Rose-John, U. Conrad, J. Scheller, Trends Biotechnol. 2010, 28, 37.

[56] C. E. Mills, Z. Michaud, B. D. Olsen, Biomacromolecules 2018, 19, 2517.

[57] A. Varanko, S. Saha, A. Chilkoti, Adv. Drug Delivery Rev. 2020, 156, 133.

[58] W. R. Strohl, Protein Cell 2018, 9, 86

[59] U. Conrad, I. Plagmann, S. Malchow, M. Sack, D. M. Floss, A. A. Kruglov, S. A. Nedospasov, S. Rose-John, J. Scheller, Plant Biotechnol. J. 2011, 9, 22.

[60] W. H. Toh, J. Louber, I. S. Mahmoud, J. Chia, G. T. Bass, S. K. Dower, A. M. Verhagen, P. A. Gleeson, J. Cell Sci. 2020, 133.

[61] K. M. Murphy, C. Weaver, Janeway's Immunobiology (Ed: G. Science), Taylor and Francis Group, London, UK 2016.

[62] M. Cavaco, M. Castanho, V. Neves, Biopolymers 2017, 110, 23095 .

[63] G. Vidarsson, G. Dekkers, T. Rispens, Front. Immunol. 2014, 110, e23095

[64] P. R. Hinton, M. G. Johlfs, J. M. Xiong, K. Hanestad, K. C. Ong, C. Bullock, S. Keller, M. T. Tang, J. Y. Tso, M. Vasquez, N. Tsurushita, J. Biol. Chem. 2004, 279, 6213.

[65] W. F. Dall'Acqua, R. M. Woods, E. S. Ward, S. R. Palaszynski, N. K. Patel, Y. A. Brewah, H. Wu, P. A. Kiener, S. Langermann, J. Immunol. 2002, 169, 5171.

[66] W. F. Dall'Acqua, P. A. Kiener, H. Wu, J. Biol. Chem. 2006, 281, 23514 .

[67] a) R. S. Blumberg, D. Lillicrap, G. F. I. T. G. Ig, Blood 2018, 131, 2205; b) A. Kessel, H. Ammuri, R. Peri, E. R. Pavlotzky, M. Blank, Y. Shoenfeld, E. Toubi, J. Immunol. 2007, 179, 5571.

[68] S. Zhao, E. Mysler, R. J. Moots, Immunotherapy 2018, 10, 433.

[69] A. Srivastava, A. K. Brewer, E. P. Mauser-Bunschoten, N. S. Key, S. Kitchen, A. Llinas, C. A. Ludlam, J. N. Mahlangu, K. Mulder, M. C. Poon, A. Street, 2013, 19, el.

[70] L. Graf, Transfus. Med. Hemother. 2018, 45, 86. 
[71] a) J. S. Powell, N. C. Josephson, D. Quon, M. V. Ragni, G. Cheng, E. Li, H. Jiang, L. Li, J. A. Dumont, J. Goyal, X. Zhang, J. Sommer, J. McCue, M. Barbetti, A. Luk, G. F. Pierce, Blood 2012, 119, 3031; b) G. Young, J. Mahlangu, R. Kulkarni, B. Nolan, R. Liesner J. Pasi, C. Barnes, S. Neelakantan, G. Gambino, L. M. Cristiano, G. F. Pierce, G. Allen, J. Thromb. Haemostasis 2015, 13, 967.

[72] S. L. Meeks, S. Lacroix-Desmazes, Haemophilia 2020, 26, 958

[73] A. Zorzi, S. Linciano, A. Angelini, MedChemComm 2019, 10, 1068.

[74] M. Bern, K. M. Sand, J. Nilsen, I. Sandlie, J. T. Andersen, J. Controlled Release 2015, 211, 144

[75] D. Sleep, J. Cameron, L. R. Evans, Biochim. Biophys. Acta, Gen. Subj. 2013, 1830, 5526

[76] a) J. T. Andersen, B. Dalhus, D. Viuff, B. T. Ravn, K. S. Gunnarsen, A. Plumridge, K. Bunting, F. Antunes, R. Williamson, S. Athwal, E. Allan, L. Evans, M. Bjørås, S. Kjærulff, D. Sleep, I. Sandlie, J. Cameron, J. Biol. Chem. 2014, 289, 13492; b) M. Bern J. Nilsen, M. Ferrarese, K. M. K. Sand, T. T. Gjølberg, H. E. Lode, R. J. Davidson, R. M. Camire, E. S. Bækkevold, S. Foss, A. Grevys, B. Dalhus, J. Wilson, L. S. Høydahl, G. J. Christianson, D. C. Roopenian, T. Schlothauer, T. E. Michaelsen, M. C. Moe, S. Lombardi, M. Pinotti, I. Sandlie, A. Branchini, J. T. Andersen, Sci. Transl. Med. 2020, 12.

[77] S. S. Petersen, E. Klaning, M. F. Ebbesen, B. Andersen, J. Cameron, E. S. Sorensen, K. A. Howard, Mol. Pharm. 2016, 13, 677.

[78] V. E. Kenanova, T. Olafsen, F. B. Salazar, L. E. Williams, S. Knowles, A. M. Wu, Protein Eng., Des. Sel. 2010, 23, 789.

[79] M. Bak, J. Park, K. Min, J. Cho, J. Seong, Y. S. Hahn, G. Tae, I. Kwon, Pharmaceutics 2020, 12, 364

[80] a) J. Schmøkel, A. Voldum, G. Tsakiridou, M. Kuhlmann, J. Cameron, E. S. Sørensen, J. Wengel, K. A. Howard, Nanotechnology 2017, 28, 204004; b) M. Simon, R. Frey, U. Zangemeister-Wittke, A. Plückthun, Bioconjugate Chem. 2013, 24, 1955; c) D. Müller, A. Karle, B. Meißburger, I. Höfig, R. Stork, R. E. Kontermann, J. Biol. Chem. 2007, 282, 12650

[81] E. M. Bech, S. L. Pedersen, K. J. Jensen, ACS Med. Chem. Lett. 2018, 9, 577

[82] J. Lau, P. Bloch, L. Schaffer, I. Pettersson, J. Spetzler, J. Kofoed, K. Madsen, L. B. Knudsen, J. McGuire, D. B. Steensgaard, H. M. Strauss, D. X. Gram, S. M. Knudsen, F. S. Nielsen, P. Thygesen, S. Reedtz-Runge, T. Kruse, J. Med. Chem. 2015, 58 7370

[83] R. Juul Kildemoes, M. Hojby Rasmussen, H. Agerso, R. V. Overgaard, J. Clin. Endocrinol. Metab. 2021, 106, 567.

[84] J. Cho, J. Park, G. Tae, M. S. Jin, I. Kwon, Biomedicines 2020, 8, 96.

[85] L. B. Knudsen, J. Lau, Front. Endocrinol. 2019, 10, 155.

[86] S. I. Lim, Y. Mizuta, A. Takasu, Y. S. Hahn, Y. H. Kim, I. Kwon, J. Controlled Release 2013, 170, 219

[87] J. Cho, S. I. Lim, B. S. Yang, Y. S. Hahn, I. Kwon, Sci. Rep. 2017, 7 18041.

[88] C. Fu, Q. Chen, F. Zheng, L. Yang, H. Li, Q. Zhao, X. Wang, L. Wang, Q. Wang, Angew. Chem., Int. Ed. Engl. 2019, 58, 1392.

[89] J. Cho, J. Park, S. Kim, J. C. Kim, G. Tae, M. S. Jin, I. Kwon, J. Controlled Release 2020, 321, 49.

[90] M. U. Johansson, I.-M. Frick, H. Nilsson, P. J. Kraulis, S. Hober, P. Jonasson, M. Linhult, P.-Å. Nygren, M. Uhlén, L. Björck, T. Drakenberg, S. Forsén, M. Wikström, J. Biol. Chem. 2002, 277, 8114

[91] a) A. Jonsson, J. Dogan, N. Herne, L. Abrahmsen, P. A. Nygren, Protein Eng., Des. Sel. 2008, 21, 515; b) J. T. Andersen, R. Pehrson, V. Tolmachev, M. B. Daba, L. Abrahmsen, C. Ekblad, J. Biol. Chem. 2011, 286, 5234.

[92] R. Guo, W. Guo, L. Cao, H. Liu, J. Liu, H. Xu, W. Huang, F. Wang, Z. Hong, Int. J. Pharm. 2016, 511, 538.

[93] A. Barozzi, R. A. Lavoie, K. N. Day, R. Prodromou, S. Menegatti, Int. J. Mol. Sci. 2020, 21, 3769.
[94] a) B. M. Tijink, T. Laeremans, M. Budde, M. S. v. Walsum, T. Dreier, H. J. de Haard, C. R. Leemans, G. A. M. S. van Dongen, Mol. Cancer Ther. 2008, 7, 2288; b) H. van Faassen, S. Ryan, K. A. Henry, S. Raphael, Q. Yang, M. A. Rossotti, E. Brunette, S. Jiang, A. S. Haqqani, T. Sulea, C. R. MacKenzie, J. Tanha, G. Hussack, FASEB J. 2020, 34, 8155; c) M. R. Müller, K. Saunders, C. Grace, M. Jin, N. Piche-Nicholas, J. Steven, R. O'Dwyer, L. Wu, L. Khetemenee, Y. Vugmeyster, T. P. Hickling, L. Tchistiakova, S. Olland, D. Gill, A. Jensen, C. J. Barelle, mAbs 2014, 4, 673; d) S. Y. Cho, J. Han, S.-H. Cha, S.-i. Yoon, Biochem. Biophys. Res. Commun. 2020, 526, 941; e) D. Kim, H. Jeon, S. Ahn, W. I. Choi, S. Kim, S. Jon, J. Controlled Release 2017, 256, 114; f) D. Steiner F. W. Merz, I. Sonderegger, M. Gulotti-Georgieva, D. Villemagne, D. J. Phillips, P. Forrer, M. T. Stumpp, C. Zitt, H. K. Binz, Protein Eng., Des. Sel. 2017, 30, 583; g) M. W. Traxlmayr, J. D. Kiefer, R. R. Srinivas, E. Lobner, A. W. Tisdale, N. K. Mehta, N. J. Yang, B. Tidor, K. D. Wittrup, J. Biol. Chem. 2016, 291, 22496.

[95] a) K. A. Henry, J. Tanha, G. Hussack, Protein Eng., Des. Sel. 2015, 28, 379; b) E. Davé, R. Adams, O. Zaccheo, B. Carrington, J. E. Compson, S. Dugdale, M. Airey, S. Malcolm, H. Hailu, G. Wild, A. Turner, J. Heads, K. Sarkar, A. Ventom, D. Marshall, M. Jairaj, T. Kopotsha, L. Christodoulou, M. Zamacona, A. D. Lawson, S. Heywood, D. P. Humphreys, mAbs 2016, 8 , 1319.

[96] C. Pain, J. Dumont, M. Dumoulin, Biochimie 2015, 111, 82.

[97] a) G. Bao, M. Tang, J. Zhao, X. Zhu, EJNMMI Res. 2021, 11, 6; b) N. V. Bathula, H. Bommadevara, J. M. Hayes, Cancer Biother. Radiopharm. 2021, 36, 109; c) I. Jovcevska, S. Muyldermans, BioDrugs 2020, 34, 11

[98] a) S. Muyldermans, J. Biotechnol. 2001, 74, 277; b) M. Dumoulin, K. Conrath, A. Van Meirhaeghe, F. Meersman, K. Heremans, L. G. Frenken, S. Muyldermans, L. Wyns, A. Matagne, Protein Sci. 2002, 11, 500 .

[99] a) S. Hoefman, I. Ottevaere, J. Baumeister, M. L. Sargentini-Maier, Antibodies 2015, 141, 141; b) M. Van Roy, C. Ververken, E. Beirnaert, S. Hoefman, J. Kolkman, M. Vierboom, E. Breedveld, B. t Hart, S. Poelmans, L. Bontinck, A. Hemeryck, S. Jacobs, J. Baumeister, H. Ulrichts, Arthritis Res. Ther. 2015, 17, 135.

[100] F. Kratz, B. Elsadek, J. Controlled Release 2012, 161, 429.

[101] T. Dörner, M. Weinblatt, K. V. Beneden, E. Dombrecht, K. D. Beuf, P. Schoen, R. Zeldin, Ann. Rheum. Dis. 2017, 76, 575

[102] S. Low, H. Wu, K. Jerath, A. Tibolla, B. Fogal, R. Conrad, M. MacDougall, S. Kerr, V. Berger, R. Dave, J. Villalona, L. Pantages, J. Ahlberg, H. Li, D. Van Hoorick, C. Ververken, J. Broadwater, A. Waterman, S. Singh, R. Kroe-Barrett, mAbs 2020, 12, 1709322.

[103] K. A. Papp, M. A. Weinberg, A. Morris, K. Reich, Lancet 2021, 397, 1564.

[104] C. Vincke, R. Loris, D. Saerens, S. Martinez-Rodriguez, S. Muyldermans, K. Conrath, J. Biol. Chem. 2009, 284, 3273.

[105] K. Fan, B. Jiang, Z. Guan, J. He, D. Yang, N. Xie, G. Nie, C. Xie, X. Yan, Anal. Chem. 2018, 90, 5671.

[106] R. L. O'Connor-Semmes, J. Lin, R. J. Hodge, S. Andrews, J. Chism, A. Choudhury, D. J. Nunez, Clin. Pharmacol. Ther. 2014, 96, 704.

[107] H. K. Binz, T. R. Bakker, D. J. Phillips, A. Cornelius, C. Zitt, T. Gottler, G. Sigrist, U. Fiedler, S. Ekawardhani, I. Dolado, J. A. Saliba, G. Tresch, K. Proba, M. T. Stumpp, mAbs 2017, 9, 1262.

[108] R. D. Baird, C. Linossi, M. Middleton, S. Lord, A. Harris, J. Rodon, C. Zitt, U. Fiedler, K. M. Dawson, N. Leupin, M. T. Stumpp, A. Harstrick, A. Azaro, S. Fischer, A. Omlin, J. Clin. Oncol. 2021, 39, 145.

[109] Z. R. Crook, N. W. Nairn, J. M. Olson, Trends Biochem. Sci. 2020 45,332

[110] M. Brinkley, Bioconjugate Chem. 1992, 3, 2.

[111] F. Tekaia, E. Yeramian, B. Dujon, Gene 2002, 297, 51 
[112] a) R. Huisgen, Angew. Chem., Int. Ed. Engl. 1963, 2, 633; b) P. Shieh, C. R. Bertozzi, Org. Biomol. Chem. 2014, 12, 9307.

[113] a) P. E. Dawson, T. W. Muir, I. Clark-Lewis, S. B. Kent, Science 1994, 266, 776; b) C. B. Rosen, M. B. Francis, Nat. Chem. Biol. 2017, 13, 697.

[114] E. Jacob, R. Unger, Bioinformatics 2007, 23, 225.

[115] a) J. M. Gilmore, R. A. Scheck, A. P. Esser-Kahn, N. S. Joshi, M. B. Francis, Angew. Chem., Int. Ed. Engl. 2006, 45, 5307; b) H. Jiang, G. D. D'Agostino, P. A. Cole, D. R. Dempsey, Methods Enzymol. 2020, 639, 333; c) T. J. Sereda, C. T. Mant, A. M. Quinn, R. S. Hodges, J. Chromatogr. 1993, 646, 17.

[116] P. L. Turecek, M. J. Bossard, F. Schoetens, I. A. Ivens, J. Pharm. Sci. 2016, 105, 460.

[117] a) M. W. Jones, G. Mantovani, C. A. Blindauer, S. M. Ryan, X. Wang, D. J. Brayden, D. M. Haddleton, J. Am. Chem. Soc. 2012, 134, 7406; b) M. W. Jones, R. A. Strickland, F. F. Schumacher, S. Caddick, J. R. Baker, M. I. Gibson, D. M. Haddleton, J. Am. Chem. Soc. 2012, 134, 1847; c) Y. Cong, E. Pawlisz, P. Bryant, S. Balan, E. Laurine, R. Tommasi, R. Singh, S. Dubey, K. Peciak, M. Bird, A. Sivasankar, J. Swierkosz, M. Muroni, S. Heidelberger, M. Farys, F. Khayrzad, J. Edwards, G. Badescu, I. Hodgson, C. Heise, S. Somavarapu, J. Liddell, K. Powell, M. Zloh, J. W. Choi, A. Godwin, S. Brocchini, Bioconjugate Chem. 2012, 23, 248; d) M. A. Gauthier, H. A. Klok, Biomacromolecules 2011, 12, 482.

[118] N. Stephanopoulos, M. B. Francis, Nat. Chem. Biol. 2011, 7, 876.

[119] H. Lodish, B. Arnold, M. Paul, C. Kaiser, S. M. P, Z. LawrenceL, D. James, in Molecular Cell Biology (Ed: W. H. Freman), New York, USA 2000, p. 60.

[120] S. L. Ho, A. H. Wang, J. Taiwan Inst. Chem. Eng. 2009, 40, 123.

[121] a) F. Hatahet, L. W. Ruddock, Antioxid. Redox Signaling 2009, 11, 2807; b) G. Rajpal, P. Arvan, in Handbook of Biologically Active Peptides (Ed: A. J. Kastin), Elsevier, London, UK 2013, p. 1721.

[122] W. H. So, Y. Zhang, W. Kang, C. T. T. Wong, H. Sun, J. Xia, Curr. Opin. Biotechnol. 2017, 48, 220.

[123] a) J. Ravasco, H. Faustino, A. Trindade, P. M. P. Gois, Chemistry 2019, 25, 43; b) K. Renault, J. W. Fredy, P. Y. Renard, C. Sabot, Bioconjugate Chem. 2018, 29, 2497.

[124] C. P. Ryan, M. E. Smith, F. F. Schumacher, D. Grohmann, D. Papaioannou, G. Waksman, F. Werner, J. R. Baker, S. Caddick, Chem. Commun. 2011, 47, 5452.

[125] a) M. E. Smith, M. B. Caspersen, E. Robinson, M. Morais, A. Maruani, J. P. Nunes, K. Nicholls, M. J. Saxton, S. Caddick, J. R. Baker, V. Chudasama, Org. Biomol. Chem. 2015, 13, 7946; b) M. E. Smith, F. F. Schumacher, C. P. Ryan, L. M. Tedaldi, D. Papaioannou, G. Waksman, S. Caddick, J. R. Baker, J. Am. Chem. Soc. 2010, 132, 1960; c) J. P. Nunes, M. Morais, V. Vassileva, E. Robinson, V. S. Rajkumar, M. E. Smith, R. B. Pedley, S. Caddick, J. R. Baker, V. Chudasama, Chem. Commun. 2015, 51, 10624.

[126] A. Maruani, M. E. Smith, E. Miranda, K. A. Chester, V. Chudasama, S. Caddick, Nat. Commun. 2015, 6, 6645.

[127] D. A. Richards, S. A. Fletcher, M. Nobles, H. Kossen, L. Tedaldi, V. Chudasama, A. Tinker, J. R. Baker, Org. Biomol. Chem. 2016, 14, 455.

[128] M. Lahnsteiner, A. Kastner, J. Mayr, A. Roller, B. K. Keppler, C. R. Kowol, Chemistry 2020, 26, 15867.

[129] P. A. Szijj, C. Bahou, V. Chudasama, Drug Discovery Today Technol. 2018, 30, 27.

[130] W. Huang, X. Wu, X. Gao, Y. Yu, H. Lei, Z. Zhu, Y. Shi, Y. Chen, M. Qin, W. Wang, Y. Cao, Nat. Chem. 2019, 11, 310.

[131] B. Q. Shen, K. Xu, L. Liu, H. Raab, S. Bhakta, M. Kenrick, K. L. Parsons-Reponte, J. Tien, S. F. Yu, E. Mai, D. Li, J. Tibbitts, J. Baudys, O. M. Saad, S. J. Scales, P. J. McDonald, P. E. Hass, C. Eigenbrot, T. Nguyen, W. A. Solis, R. N. Fuji, K. M. Flagella, D. Patel, S. D. Spencer, L. A. Khawli, A. Ebens, W. L. Wong, R. Vandlen, S. Kaur, M. X. Sliwkowski, R. H. Scheller, P. Polakis, J. R. Junutula, Nat. Biotechnol. 2012, 30, 184.
[132] J. R. Junutula, H. Raab, S. Clark, S. Bhakta, D. D. Leipold, S. Weir, Y. Chen, M. Simpson, S. P. Tsai, M. S. Dennis, Y. Lu, Y. G. Meng, C. Ng, J. Yang, C. C. Lee, E. Duenas, J. Gorrell, V. Katta, A. Kim, K. McDorman, K. Flagella, R. Venook, S. Ross, S. D. Spencer, W. Lee Wong, H. B. Lowman, R. Vandlen, M. X. Sliwkowski, R. H. Scheller, P. Polakis, W. Mallet, Nat. Biotechnol. 2008, 26, 925.

[133] E. V. Vinogradova, C. Zhang, A. M. Spokoyny, B. L. Pentelute, S. L. Buchwald, Nature 2015, 526, 687

[134] a) K. Kubota, P. Dai, B. L. Pentelute, S. L. Buchwald, J. Am. Chem. Soc. 2018, 140, 3128; b) H. H. Dhanjee, A. Saebi, I. Buslov, A. R. Loftis, S. L. Buchwald, B. L. Pentelute, J. Am. Chem. Soc. 2020, 142, 9124

[135] L. Zhang, J. P. Tam, Anal. Biochem. 1996, 233, 87.

[136] a) G. J. Bernardes, M. Steiner, I. Hartmann, D. Neri, G. Casi, Nat. Protoc. 2013, 8, 2079; b) G. Casi, N. Huguenin-Dezot, K. Zuberbuhler, J. Scheuermann, D. Neri, J. Am. Chem. Soc. 2012, 134, 5887.

[137] A. Bandyopadhyay, S. Cambray, J. Gao, Chem. Sci. 2016, 7, 4589.

[138] A. R. Costa, M. E. Rodrigues, M. Henriques, R. Oliveira, J. Azeredo, Crit. Rev. Biotechnol. 2014, 34, 281.

[139] Z. Liu, J. Ou, H. Wang, X. You, M. Ye, ACS Appl. Mater. Interfaces 2016, 8, 32060.

[140] a) L. Liu, M. Yu, Y. Zhang, C. Wang, H. Lu, ACS Appl. Mater. Interfaces 2014, 6, 7823; b) W. Miao, C. Zhang, Y. Cai, Y. Zhang, H. Lu, Analyst 2016, 141, 2435; c) D. S. Bai, C. Zhang, P. Chen, S. J. Jin, G. Q. Jiang, Sci. Rep. 2017, 7, 12870.

[141] a) B. Han, J. F. Stevens, C. S. Maier, Anal. Chem. 2007, 79, 3342; b) P. P. Joshi, S. J. Yoon, W. G. Hardin, S. Emelianov, K. V. Sokolov, Bioconjugate Chem. 2013, 24, 878.

[142] a) L. Nieba, S. E. Nieba-Axmann, A. Persson, M. Hamalainen, F. Edebratt, A. Hansson, J. Lidholm, K. Magnusson, A. F. Karlsson, A. Pluckthun, Anal. Biochem. 1997, 252, 217; b) C. Cherkouk, L. Rebohle, J. Lenk, A. Keller, X. Ou, M. Laube, C. Neuber, C. Haase-Kohn, W. Skorupa, J. Pietzsch, Clin. Hemorheol. Microcirc. 2015, 61, 523; c) S. Knecht, D. Ricklin, A. N. Eberle, B. Ernst, J. Mol. Recognit. 2009, 22, 270.

[143] E. Hochuli, H. Dobeli, A. Schacher, J. Chromatogr. 1987, 411, 177.

[144] a) S. H. Uchinomiya, H. Nonaka, S. H. Fujishima, S. Tsukiji, A. Ojida, I. Hamachi, Chem. Commun. 2009, 5880; b) Y. Yang, N. Jiang, Y. T. Lai, Y. Y. Chang, X. Yang, H. Sun, H. Li, ACS Sens. 2019, 4, 1190; c) C. J. Ackerson, R. D. Powell, J. F. Hainfeld, Methods Enzymol. 2010, 481, 195.

[145] S. V. Wegner, J. P. Spatz, Angew. Chem., Int. Ed. Engl. 2013, 52, 7593.

[146] E. M. Sletten, C. R. Bertozzi, Angew. Chem., Int. Ed. Engl. 2009, 48, 6974.

[147] A. Rondon, F. Degoul, Bioconjugate Chem. 2020, 31, 159.

[148] M. L. Blackman, M. Royzen, J. M. Fox, J. Am. Chem. Soc. 2008, 130, 13518.

[149] a) R. Rossin, S. M. van den Bosch, W. Ten Hoeve, M. Carvelli, R. M. Versteegen, J. Lub, M. S. Robillard, Bioconjugate Chem. 2013, 24, 1210; b) J. B. Bequignat, N. Ty, A. Rondon, L. Taiariol, F. Degoul, D. Canitrot, M. Quintana, I. Navarro-Teulon, E. MiotNoirault, C. Boucheix, J. M. Chezal, E. Moreau, Eur. J. Med. Chem. 2020, 203, 112574

[150] M. Royzen, G. P. Yap, J. M. Fox, J. Am. Chem. Soc. 2008, 130, 3760.

[151] T. Luhmann, M. Gutmann, A. Moscaroli, M. Raschig, M. Behe, L. Meinel, ACS Biomater. Sci. Eng. 2020, 6, 425.

[152] a) S. Mushtaq, S. J. Yun, J. Jeon, Molecules 2019, 24, 3567; b) N. K. Devaraj, ACS Cent. Sci. 2018, 4, 952.

[153] a) E. S. Zimmerman, T. H. Heibeck, A. Gill, X. Li, C. J. Murray, M. R. Madlansacay, C. Tran, N. T. Uter, G. Yin, P. J. Rivers, A. Y. Yam, W. D. Wang, A. R. Steiner, S. U. Bajad, K. Penta, W. Yang, T. J. Hallam, C. D. Thanos, A. K. Sato, Bioconjugate Chem. 2014, 25, 351; b) C. Koehler, P. F. Sauter, M. Wawryszyn, G. E. Girona, 
K. Gupta, J. J. Landry, M. H. Fritz, K. Radic, J. E. Hoffmann, Z. A. Chen, J. Zou, P. S. Tan, B. Galik, S. Junttila, P. Stolt-Bergner, G. Pruneri, A. Gyenesei, C. Schultz, M. B. Biskup, H. Besir, V. Benes, J. Rappsilber, M. Jechlinger, J. O. Korbel, I. Berger, S. Braese, E. A. Lemke, Nat. Methods 2016, 13, 997.

[154] L. Wang, A. Brock, B. Herberich, P. G. Schultz, Science 2001, 292 498.

[155] T. S. Young, P. G. Schultz, J. Biol. Chem. 2010, 285, 11039.

[156] a) D. P. Nguyen, H. Lusic, H. Neumann, P. B. Kapadnis, A. Deiters, J. W. Chin, J. Am. Chem. Soc. 2009, 131, 8720; b) W. Liu A. Brock, S. Chen, S. Chen, P. G. Schultz, Nat. Methods 2007 4, 239; c) M. L. Tsao, D. Summerer, Y. Ryu, P. G. Schultz, J. Am. Chem. Soc. 2006, 128, 4572.

[157] L. Jakob, A. Gust, D. Grohmann, Biochem. Biophys. Rep. 2019, 17, 1.

[158] K. Ozawa, K. V. Loscha, K. V. Kuppan, C. T. Loh, N. E. Dixon, G. Otting, Biochem. Biophys. Res. Commun. 2012, 418, 652

[159] J. A. Prescher, C. R. Bertozzi, Nat. Chem. Biol. 2005, 1, 13.

[160] Y. Zhang, K. Y. Park, K. F. Suazo, M. D. Distefano, Chem. Soc. Rev. 2018, 47, 9106.

[161] a) Y. Wang, C. Wu, Biomacromolecules 2018, 19, 1804 b) D. Schumacher, J. Helma, A. F. L. Schneider, H. Leonhardt, C. P. R. Hackenberger, Angew. Chem., Int. Ed. Engl. 2018, 57, 2314; c) T. Pleiner, M. Bates, S. Trakhanov, C. T. Lee, J. E. Schliep, H. Chug, M. Bohning, H. Stark, H. Urlaub, D. Gorlich, Elife 2015, 4, e11349.

[162] T. Sano, S. Vajda, C. R. Cantor, J. Chromatogr. B: Biomed. Sci. Appl. $1998,715,85$

163] A. Chapman-Smith, J. E. Cronan Jr., Biomol. Eng. 1999, 16, 119.

[164] M. Fairhead, M. Howarth, Methods Mol. Biol. 2015, 1266, 171.

[165] a) A. Kulyyassov, V. Ogryzko, Biomolecules 2020, 10; b) K. Schilders, E. Eenjes, G. Edel, A. B. de Munck, M. B. van Kempen, J. Demmers, R. Wijnen, D. Tibboel, R. J. Rottier, Transgenic Res. 2018, 27, 142; C) S. Maiti, P. Paira, Eur. J. Med. Chem. 2018, 145, 206.

[166] H. P. Lesch, M. U. Kaikkonen, J. T. Pikkarainen, S. Yla-Herttuala, Expert Opin. Drug Delivery 2010, 7, 551.

[167] a) N. Pishesha, J. R. Ingram, H. L. Ploegh, Annu. Rev. Cell Dev. Biol. 2018, 34, 163; b) F. B. H. Rehm, T. J. Harmand, K. Yap, T. Durek, D. J. Craik, H. L. Ploegh, J. Am. Chem. Soc. 2019, 141, 17388.

[168] T. J. Harmand, D. Bousbaine, A. Chan, X. Zhang, D. R. Liu, J. P. Tam, H. L. Ploegh, Bioconjugate Chem. 2018, 29, 3245.

[169] a) C. P. Guimaraes, M. D. Witte, C. S. Theile, G. Bozkurt, L. Kundrat, A. E. Blom, H. L. Ploegh, Nat. Protoc. 2013, 8, 1787; b) C. S. Theile, M. D. Witte, A. E. Blom, L. Kundrat, H. L. Ploegh, C. P. Guimaraes, Nat. Protoc. 2013, 8, 1800.

[170] M. W. Popp, S. K. Dougan, T. Y. Chuang, E. Spooner, H. L. Ploegh, Proc. Natl. Acad. Sci. USA 2011, 108, 3169.

[171] L. Chen, J. Cohen, X. Song, A. Zhao, Z. Ye, C. J. Feulner, P. Doonan, W. Somers, L. Lin, P. R. Chen, Sci. Rep. 2016, 6, 31899.

[172] J. Li, Y. Zhang, O. Soubias, D. Khago, F. A. Chao, Y. Li, K. Shaw, R. A. Byrd, J. Biol. Chem. 2020, 295, 2664.

[173] X. Hemu, A. El Sahili, S. Hu, K. Wong, Y. Chen, Y. H. Wong, X. Zhang, A. Serra, B. C. Goh, D. A. Darwis, M. W. Chen, S. K. Sze, C. F. Liu, J. Lescar, J. P. Tam, Proc. Natl. Acad. Sci. USA 2019, 116, 11737.
[174] X. Hemu, J. To, X. Zhang, J. P. Tam, J. Org. Chem. 2020, 85, 1504.

[175] S. Massa, N. Vikani, C. Betti, S. Ballet, S. Vanderhaegen, J. Steyaert, B. Descamps, C. Vanhove, A. Bunschoten, F. W. van Leeuwen, S. Hernot, V. Caveliers, T. Lahoutte, S. Muyldermans, C. Xavier, N. Devoogdt, Contrast Media Mol. Imaging 2016, 11, 328.

[176] J. Jiao, J. Zhang, F. Yang, W. Song, D. Han, W. Wen, W. Qin, Eur. J. Pharm. Biopharm. 2020, 152, 123

[177] P. Debie, N. Devoogdt, S. Hernot, Antibodies 2019, 8, 12.

[178] Z. Wang, D. Zhang, X. Hemu, S. Hu, J. To, X. Zhang, J. Lescar J. P. Tam, C. F. Liu, Theranostics 2021, 11, 5863.

[179] Y. Deng, B. Zheng, Y. Liu, S. Shi, J. Nie, T. Wu, P. Zheng, J. Vis. Exp. 2020, 156, e60774.

[180] R. Yang, Y. H. Wong, G. K. T. Nguyen, J. P. Tam, J. Lescar, B. Wu, J. Am. Chem. Soc. 2017, 139, 5351.

[181] M. D. Lee, W. Y. Tong, T. Nebl, L. A. Pearce, T. M. Pham, A. GolbazHagh, S. Puttick, S. Rose, T. E. Adams, C. C. Williams, Bioconjugate Chem. 2019, 30, 2539.

[182] a) M. Ezban, M. Hansen, M. Kjalke, Haemophilia 2020, 26, 156; b) E. Santagostino, M. E. Mancuso, Drug Des., Dev. Ther. 2018, 12, 2933

[183] H. Ostergaard, J. R. Bjelke, L. Hansen, L. C. Petersen, A. A. Pedersen, T. Elm, F. Moller, M. B. Hermit, P. K. Holm, T. N. Krogh, J. M. Petersen, M. Ezban, B. B. Sorensen, M. D. Andersen, H. Agerso, H. Ahmadian, K. W. Balling, M. L. Christiansen, K. Knobe, T. C. Nichols, S. E. Bjorn, M. Tranholm, Blood 2011, 118, 2333.

[184] B. Ramakrishnan, P. K. Qasba, J. Biol. Chem. 2002, 277, 20833.

[185] Q. Zhou, J. E. Stefano, C. Manning, J. Kyazike, B. Chen, D. A. Gianolio, A. Park, M. Busch, J. Bird, X. Zheng, H. SimondsMannes, J. Kim, R. C. Gregory, R. J. Miller, W. H. Brondyk, P. K. Dhal, C. Q. Pan, Bioconjugate Chem. 2014, 25, 510.

[186] a) B. M. Zeglis, C. B. Davis, R. Aggeler, H. C. Kang, A. Chen, B. J. Agnew, J. S. Lewis, Bioconjugate Chem. 2013, 24, 1057; b) B. E. Cook, R. Membreno, B. M. Zeglis, Bioconjugate Chem. 2018, 29, 2734; c) R. van Geel, M. A. Wijdeven, R. Heesbeen, J. M. Verkade, A. A. Wasiel, S. S. van Berkel, F. L. van Delft, Biocon jugate Chem. 2015, 26, 2233.

[187] K. von Figura, B. Schmidt, T. Selmer, T. Dierks, BioEssays 1998, 20 505.

[188] M. J. Appel, C. R. Bertozzi, ACS Chem. Biol. 2015, 10, 72.

[189] a) R. M. Barfield, D. Rabuka, Methods Mol. Biol. 2018, 1728, 3 ; b) D. Rabuka, J. S. Rush, G. W. deHart, P. Wu, C. R. Bertozzi, Nat. Protoc. 2012, 7, 1052; c) I. Rupniewski, D. Rabuka, Methods Mol. Biol. 2019, 2012, 63.

[190] a) I. S. Carrico, B. L. Carlson, C. R. Bertozzi, Nat. Chem. Biol. 2007, 3, 321; b) P. M. Drake, A. E. Albers, J. Baker, S. Banas, R. M. Barfield, A. S. Bhat, G. W. de Hart, A. W. Garofalo, P. Holder, L. C. Jones, R. Kudirka, J. McFarland, W. Zmolek, D. Rabuka, Bioconjugate Chem. 2014, 25, 1331; c) T. Kruger, S. Weiland, G. Falck, M. Gerlach, M. Boschanski, S. Alam, K. M. Muller, T. Dierks, N. Sewald, Angew. Chem., Int. Ed. Engl. 2018, 57, 7245.

[191] M. Knop, T. Q. Dang, G. Jeschke, F. P. Seebeck, ChemBioChem 2017, 18, 161. 


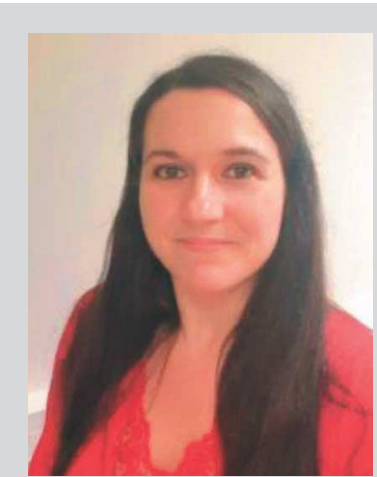

Aurélie Rondon obtained her Ph.D. at the University Clermont-Auvergne, in France, in 2018 working at the Inserm UMR1240 IMOST lab, under the supervision of Dr. Françoise Degoul. Her thesis focused on bioorthogonal click chemistry applied to pretargeted imaging and radioimmunotherapy of metastatic colorectal cancer. In 2019, she moved to the Advanced Drug Delivery and Biomaterials lab from the Louvain Drug Research Institute, UCLouvain, Brussels, Belgium, where she is a postdoctoral researcher in the group of Prof. Rita Vanbever. Her work focuses on developing single-domain antibody bioconjugates for pulmonary delivery and characterizing their biodistribution with NIRF imaging.
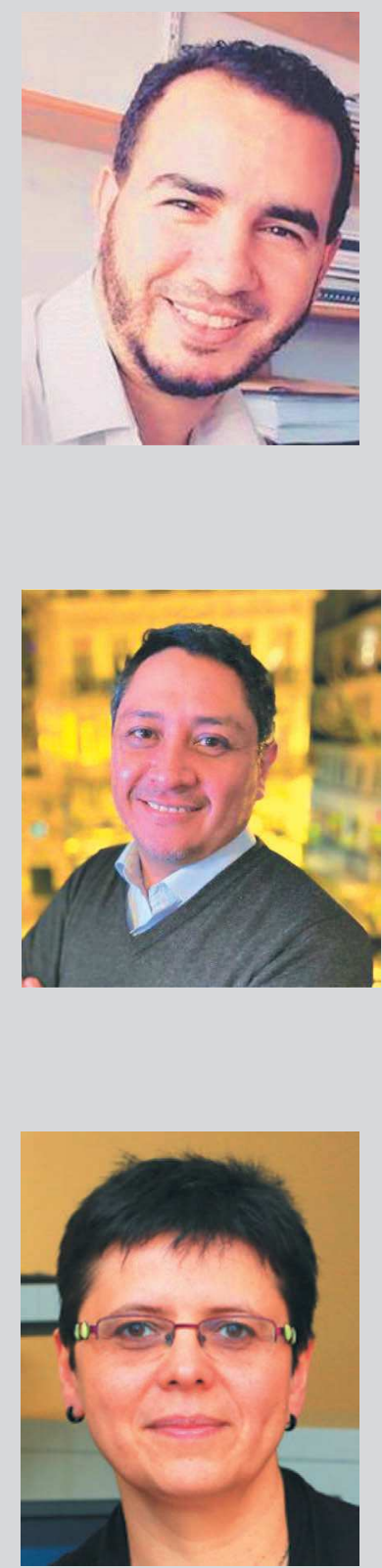

Sohaib Mahri is a postdoctoral researcher at the Louvain Drug Research Institute, UCLouvain, Belgium. Sohaib works on delivery of therapeutic proteins to the lungs. He obtained his Ph.D. degree in biomedical and pharmaceutical sciences from the same university (2020), working on elucidating the mechanisms of lung retention of PEGylated rhDNase. Before starting his Ph.D. Sohaib completed a joint M.Sc. in Chemical Innovation and Regulation from the University of Algarve (Portugal) and Heriot-Watt University (Scotland). Sohaib holds a Diploma in Pharmacy and a Diploma in Toxicology from the University of Algiers (2008 and 2012).

Francisco Morales-Yanez is a postdoctoral researcher in the group of Dr. Mireille Dumoulin at the University of Liège, Belgium. He is a medical doctor from the Universidad Central del Ecuador and holds a Master in Microbiology of the Universidad San Francisco de Quito (Ecuador). He obtained a Master in Molecular Biology (2013) and a Ph.D. in Bioengineering Sciences (2019) from the Vrije Universiteit Brussel, Belgium. His current research is focused on the isolation, characterization and engineering of single domain antibodies from camelids (nanobodies) for therapeutic and diagnostic applications.

Mireille Dumoulin is a biochemist. She is principal investigator at the Center for Protein Engineering (CIP) at the University of Liège, Belgium. Her research is based on the use of camelid single-domain antibody fragments, also referred to as nanobodies, to explore the structure and function of proteins in physiological and pathological conditions. Her main proteins of interest are: alpha-synuclein in the context of Parkinson's disease and several enzymes associated with lung inflammatory diseases. She has developed a phage display platform at CIP for the selection of nanobodies from large combinatorial libraries. 


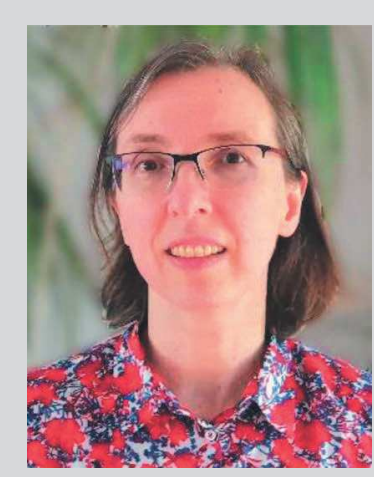

Rita Vanbever is principal investigator at the Louvain Drug Research Institute and Professor at the Faculty of Pharmacy and Biomedical Sciences of UCLouvain in Brussels, Belgium. Her research interests include the formulation of inhalation dry powders, the study of the pulmonary fate of actives, the use of pulmonary vaccination to fight respiratory infections and lung cancer and formulation strategies to sustain drug release within the lungs. These last years, she has especially focused her research on PEGylation as an approach to prolong the residence time and therapeutic activity of proteins and small molecule drugs in the lungs. 